\title{
THE CHERY:
}

$20 \times 10,2000$

$30 \times 10.00 \%$

$20 \times 20.02 \times 2 \times 2 \%$

$S$ B

379

C.5 K 2

Minits. L

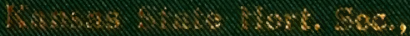

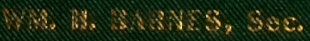

A. 


$$
\gamma
$$


vousermerits ot

William H. Barnes,

Soeretary 






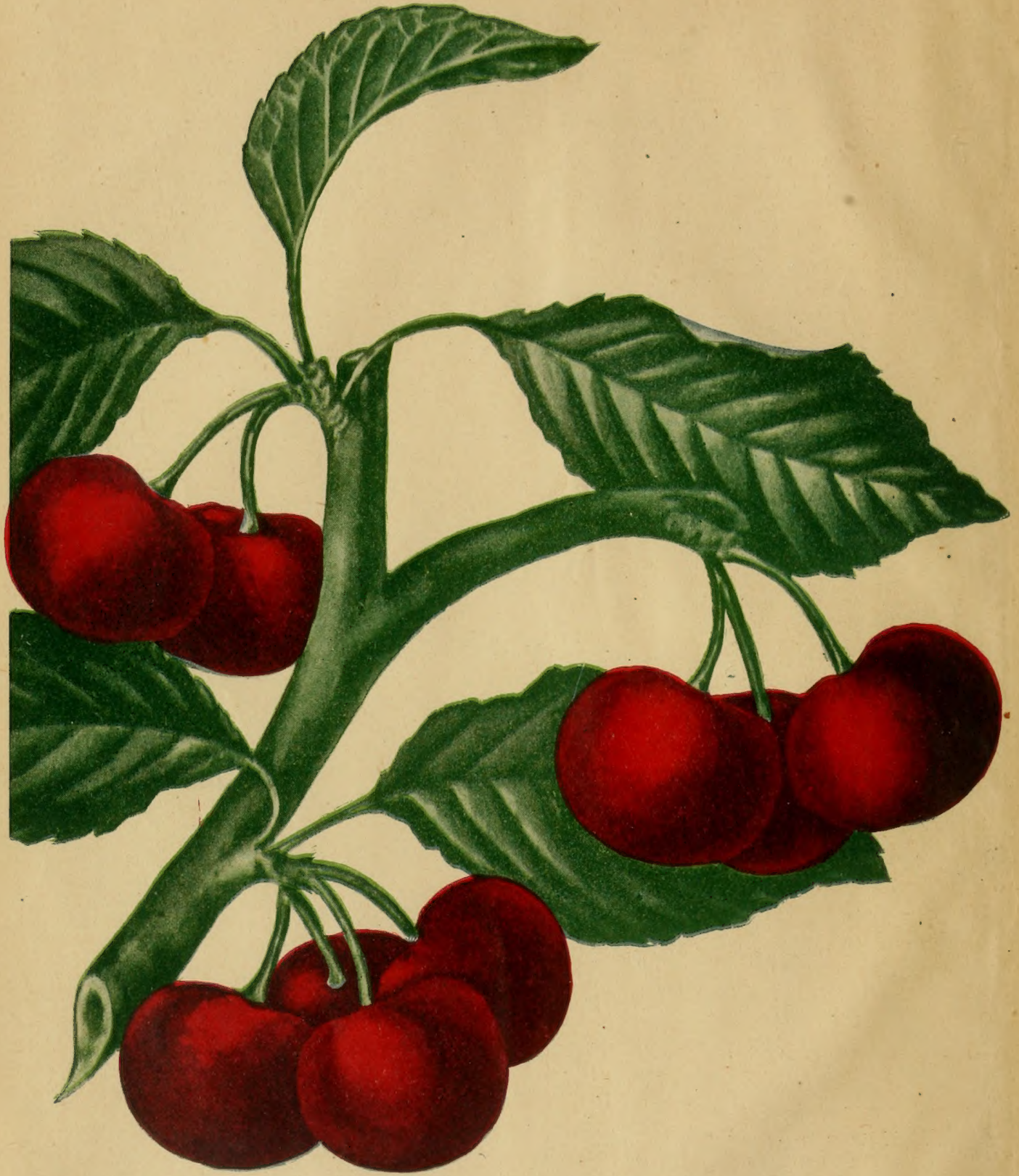

COPYRIGHT NC. 4929.

\section{THE BALDWIN CHERRY.}

Tree an upright, vigorous grower, forming a round head; leaves large and broad; bloom pure white, changing to pink; fruit large, almost round, very dark transparent wine color; flavor slightly acid, yet the sweetest and richest of the Morello type; stems rather large, of medium length, and generally in pairs. Unexcelled in earliness, vigor, hardiness, quality and productiveness. Out of 800 trees it readily attracted attention as being the most thrifty and beautiful. The original tree was planted eight years ago and has fruited five years, and is now one-third larger than any Early Richmond tree of the same age in same orchard near Seneca, Kansas, on the grounds of S. J. Baldwin the introducer. 


\section{THE CHERRY IN KANSAS,}

WITH A CHAPTER ON THE APRICOT AND NECTARINE.

"Cherries ARe Ripe!"

Makes boys, birds and everybody happy.

"Cherry Pie"

Fits every appetite, and little is left for tramps.

OUR HORTICULTURISTS SHOULD BE

BETTER ACQUAINTED WITH

\section{APRICOTS AND NECTARINES.}

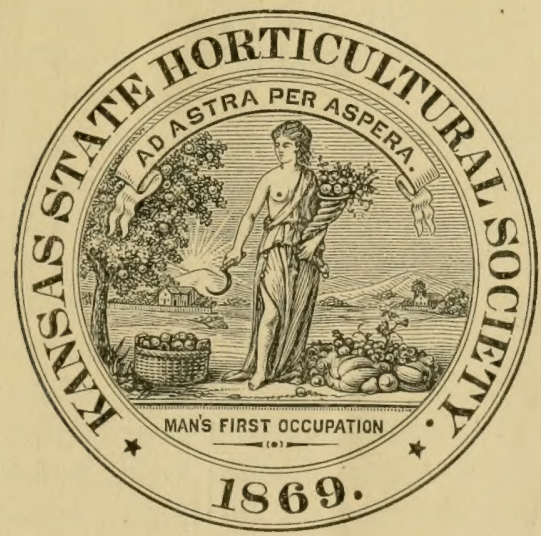

COMPILED AND REVISED FOR THE

KANSAS STATE HORTICULTURAL SOCIETY,

By William H. BARNES, Secretary, State Capitol, Topeka, Kan.

LIBRARY OF CONGRESS, RECEIVED

ISSUED BY THE STATE,

1900 . 
JUL 231901 $D$. of $D$.

$\operatorname{sis}^{3} x^{9} k^{2}$ 


\section{THE CHERRY.}

\section{DEFINITIONS.}

Stundard Dirtionary: (1) A tree or shrub of the genus Prumus (which also includes the plum), bearing a fleshy drupe with a bony stone. ( ( ) The common garden cherry ( $P$. cerasus), of which several hundred varieties are cultivated for the fruit, some of which are, the Bigarreau, Blackheart, Black Tartarian, ()xheart, Morelle or Morello, May Duke (corrujted from Medoc, of France). (b) The wild cherry: as, $P$. serotine (wild black cherry), valued for its timber. $I$ '. virginiana (choke cherry), an American shrub which bears astringent. fruit. $P$. avium and $P$. padus, European tree (bird cherry).

('entury Dictionary: (1) The fruit of a species of C'erasus (which is commonly regarded as a subgenus of Prumus), consisting of a globose pulpy drupe enclosing a one-seeded, smooth stone. The cultivated varieties of the garden cherry probably all belong to two species, $P$. reverus and $I^{\prime}$. arimm, both doubtless natives of Europe. It is related by Pliny that this fruit or a cultivated variety of it was brought from Cerasus in Pontus to Italy after the defeat of Mithridates by Lucellus, about 70 B. C. It was introduced into England by the Romans about 120 years afterward. There are many kinds, as the red, black and white hearted, the May Duke, Bigarreau, Morello, Kentish, etc. The will or crab cherry, Mazzard or Gean of Great Britain, in a wild state of the $T^{\prime}$. arium, which is also found in varions other parts of Europe. From the fruit of its different varieties several highly esteemed cordials are prepared, as the Maraschino of Italy, the Ratafia of France, the Kirschwasser of Germany, etc. To this groul' of cherries, distinguished by having their flowers and fruits in clusters, belong also the Mahaleb cherry ( $P$. mahaleb) of Europe, with very fragrant flowers, and the ground-cherry ( $P$. pennsyleanica), and the dwarf cherry ( $P$. pumila), of North America. A second section of the genus has the fluwer in racemes, and the fruit smaller and less palatable. To this belong the bird-cherry (P.padus) of Europe, and the wild black cherry, also called the rum or cabinet cherry ( $P$. serotina), and the cholie-cherry ( $P$. virginiana) of America. Still a third section consists of evergreen trees, with the flowers in racemes and the 
fruit inedible, including the bastard cherry, bay-cherry or laurel-cherry ( $P$. lauro-cerasus) of Europe, and the Carolina laurel-cherry ( $P$. carolinana) of the southern United States.

OXHEART.-A large variety of cherry, so called from its shape.

Morello.-A kind of cherry with a dark red skin, becoming nearly black if allowed to hang long. The flesh is deep purplish red, tender, juicy, and acid. It is a standard cherry, much used in cooking and preserved in brandy.

MaY Duke.-(A corruption of Medoc, a district near Bordeaux, France, from which these cherries were introduced.) A variety of cherry of the sour type.

\section{THE CHERRY IN KANSAS.}

Our people have hardly come up to a full understanding of the value of this fruit. Our markets are never one-quarter supplied and the demand is increasing. Occasionally a horticulturist who for some unaccountable reason put out few or many cherry trees is greatly surprised when they come into bearing to find them a bonanza. Growers near our larger towns are enthusiastic over the nice returns. Several of our growers claim a profit of $\$ 250$ per acre from their cherries. They are almost a sure crop year by year. Coming early, the first of the tree fruits, the trees have a long growing season in which to recuperate, and prepare material for a crop the following season. While the crop of cherries varies in quantity yet there is almost never a total failure. Heavy spring frosts are most to be feared. The curculio, the aphis and birds affect them some, but still we have cherries, and the young robins and other fledglings amnually build up their systems upon such choice delicacies as Richmond, Montmorency, etc. For the aphis we should spray, for curculio jar, for the birts, bells, stuffed cats, hawks, etc., are used; but we should plant more; we can grow su many in our soil and climate that the birds cannot increase in proportion; besides, after cherries are gone, and healthy bird appetites remain, the insects are devoured next. Plant cherries! We have not yet found a sweet cherry that is sure here. Ostheim is good. Governor Wrood is uncertain. As the sour cherry tree grows low and wide, we cannot do as the Europeans, plant cherry trees along the roadside; but our lands are chenp, and we might get a fine income from many a waste acre if planted to cherries. They are as early to market as berries, and sell as readily. No fruit is preferable for canning, and cherry pie is the choicest of pies. 
"Can she make a cherry pie

Billy boy, Billy boy?

Can she make a cherry pie,

Charming Billy?

Yes, she can make a cherry pie,

The top notch for you and I,

But the young thing will never leave her mother."

This girl knew how to "touch" Billy in the right spot, but she" wanted to stay with the one who had taught her the secret, as she knew there was more a comin'. See recipes in this book.

\section{THE CHERRY.}

From Downing's "Fruit and Fruit-trees of Amercia."

Cerasus sylvestris, and $C$.vulgaris, Arb. Brit. Rosacea, of the botanist. Cerisier, of the French. Kirschenbcum, German. Ciriego, Italian. Cerezo, Spanish.

The cherry is a fine, huxuriant fruit-tree, with smooth, light-colored bark, and generally of rapid growth. The varieties of the black and heart-shaped cherries are always vigorous, and form fine, large. spreading heads, forty or fifty feet in height; but those of the acid or red cherry are of lower, more bushy and tardy growth. In the spring the cherry tree is prof usely covered with clusters of snow-white blossoms, and earlier in the summer than upon any other tree. These are followed by abundant crops of juicy, sweet or acid fruit, hanging upon long stalks, and enclosing a smooth stone. The cherry comes originally from Asia, and the Roman general, Lucullus, after a victorious expedition into Pontus, has the reputation of having brought it to Italy from Cerasus, a town in that province, in the year $69 \mathrm{~B}$. C. According to Pliny, the Romans, 100 years after this, had eight rarieties in cultivation, and they were soon afterwards carried to all parts of Europe. The seeds of the cultivated cherry were brought to this country very early after its settlement both from England and Holland.

UsEs:- As pleasant and refreshing dessert fruit the cherry is everywhere esteemed. The early season at which it ripens, its jujciness, delicacy, and richness, render it always acceptahle. While the large and fleshy varieties are exceedingly sweet and luscious, others, which are more tender and more or less acid, are very valuable for pies. tarts, and various kinds of cookery. The fruit of the Kentish or Early Richmond is excellent when stoned and dried, and the Mazzard and our wild Virginia cherries are used to yive a flavor to brandy. When canned, they retain their character and are very delicious. The 
Dukes or Merellos are best for their purpose. The celebrated German Kirschwasser is made by distilling the liquor of the common black Mazzard or Gean (in which the stones are ground or broken and fermented with the pulp), and the delicious Ratafia cordial of Grenoble is also made from this fruit. Maraschino, the most celebrated liquor of Italy, is distilled from a small Gean or Mazzard, with which, in fermenting, honey and the leaves and kernels of the fruit are mixed.

The gum of the cherry is nearly identical with gum arabic, and there are some marvelous stories told of its nutritive properties. The wood of the cherry is hard and durable, and is therefore valuable for many purposes; but the best wood is afforded by our wild or Virginia cherry, which is a very good substitute for mahogany, taking a fine polish.

The large-growing sorts of black cherry are the finest of all fruittrees for shade, and are therefore generally chosen by farmers who are always desirous of combining the useful and the ornamental. Indeed, the cherry, from its symmetrical form, its rapid growth, its fine shade and beautiful blossoms, is exceedingly well suited for a road-side tree in agricultural districts. We wish we could induce the planting of avenues of this and other fine-growing fruit-trees in our country neighborhoods, as is the beautiful custom in Germany, affording ornament and a grateful shade to the traveler at the same moment. Mr. Loudon, in his "Arboretum," gives the following account of the cherry avenues in Germany, which we gladly lay before our readers :

On the continent, and more especially in Germany and Switzerland, the cherry is much used as a roadside tree; particularly in the northern part of Germany, where the apple and the pear will not thrive. In some countries the road passes for miles together through an avenue of cherry trees. In Moravia, the road from Brunn to Olmutz passes through such an avenue, extending upwards of sixty miles in length; and in the autumn of 1828 we traveled for several days through almost one continuous avenue of cherry trees, from Strasburg by a circuitous route to Munich. These avenues, in Germany, are planted by the desire of the respective governments, not only for shading the traveler, but in order that the poor pedestrian may obtain refreshment on his journey. All persons are allowed to partake of the cherries, on condition of not injuring the trees, but the main crop of the cherries, when ripe, is gathered by the respective proprietors of the land on which it grows; and when these are anxious to preserve the fruit of any particular tree, it is, as it were, tabooed; that is, a whisp of straw is tied in a conspicuous part of one of the branches, as vines by the roadside in France, when the grapes are ripe, are protected by sprinkling a plant here and there with a mixture of lime and water, which marks the leaves with conspicuous white blotches. Every one who has traveled on the continent in the fruit season must have observed the respect that is paid to these appropriating marks; and there is something highly gratifying in this, and in the humane feeling dis- 
played by the princes of the different countries in causing the trees to be planted. It would indeed be lamentable if kind treatment did not produce a corresponding return.

Soll ANd Situation- - A dry soil for the cherry is a universal maxim, and although it is so hardy a tree that it will thrive in a great variety of soils, yet a good sandy or gravelly loam is its favorite place. It will indeed grow in much thinner and dryer soils than most other fruit-trees, but to obtain the finest fruit a deep and mellow soil of good quality is desirable. When it is forced to grow in wet places, or where the roots are constantly damp, it soon decays and is shortlived. And we have seen this tree, when forced into too luxuriant a growth in our overrich Western soils, become so gross in its wood as to bear little or no fruit, and split open in its trunk, and soon perish. It is a very hardy tree, and will bear a great variety of exposures without injury. In deep, warm valleys, liable to spring frosts, it is, however, well to plant it on the north side of hills, in order to retard it in the spring.

Propagation.- The finer sorts are nearly always propagated by budding on seedlings of the common black Mazzard, which is a very common kind, producing a great abundance of fruit, and very healthy, free-growing stocks. To raise these stocks, the cherries should be gathered when fully ripe, and allowed to lie two or three days together, so that they may be partially or wholly freed from the pulp by washing them in water. They should then be planted immediately in drills in the seed plat, covering them about an inch deep. They will then vegetate in the following spring, and in good soil will be fit for planting out in the nursery rows in the autumn or following spring: at a distance of ten or twelve inches apart in the row. Many persons preserve their cherry-stones in sand, either in the cellar or in the open air, until spring, but we have found this a more precarious mode: the cherry being one of the most delicate of seeds when it commences to vegetate, its vitality is frequently destroyed by leaving it in the sand twenty-four hours too long, or after it has commenced sprouting.

After planting in the nursery rows, the seedlings are generally fit for budding in the month of August following. And in order not to have weak stocks overpowered by vigorous ones, they should always be assorted before they are planted, placing those of the same size in rows together. Nearly all the cherries are grown with us as standards. The English nurserymen usually bud their standard cherries as high as they wish theni to form heads, but we always prefer to bud them on quite young stocks, as near the ground as possible, as they then shoot up clean, straight, smooth stems, showing no clumsy joint where the bud and the stock are united. In good soils the buds will fre- 
quently make shoots six to eight feet high the first season after the stock is headed back. Grafting of the cherry may be performed the same as with the apple and pear, but the work, to be successful, should always be performed early in the season, before the frost is well out of the ground. If omitted until the buds begin to swell strongly, the chances of success are less than those of failure.

When dwarf trees are required, the Morello seedlings are used as stocks, or the Perfumed cherry (Cerasus malialch) is employed; but as standards are almost universally preferred, these are seldom seen here. Dwarfs in the nursery must be headed back the second year, in order to form lateral shoots near the ground.

Cultivation.--The cherry, as a standard tree, may be said to require little or no cultivation in the Middle states, further than occasionally supplying old trees with a little manure, to keep up their vigor, pruning out a dead or crossing branch, and washing the stem with soft soap should it become hard and bark-bound. Pruning, the cherry very little needs, and as it is always likely to produce gum (and this decay), it should be avoided, except when really required. It should then be done in midsummer, as that is the only season when the gum is not more or less exuded. The cherry is not a very longlived tree, but in favorable soil the finest varieties generally endure about thirty or forty years. In the county of Perry, Ohio, there is a tree of the Black Mazzard variety which is eighty feet high, and four feet one inch in diameter of main trunk, while the length of the largest limb or branch is forty-two feet. A large cherry tree at Walworth, N. Y., is recorded as measuring fourteen feet six inches in circumference, sixty feet in height, and having a spread of over four rods. It has produced forty bushels of fruit in one serson. Twenty feet apart for the strong, and eighteen feet for the slow-growing kinds, is the proper distance.

Gathering the Fruit.-This tender and juicy fruit is best when freshly gathered from the tree, and it should always be picked with the stalks attached. For the dessert, the flavor of many sorts in our climate is rendered more delicious by placing the fruit, for an hour or two previous, in an ice-house or refrigerator, and bringing them upon the table cool, with dew-drops standing upon them. For the market or transportation long distances, they should be gathered only when perfectly dry. 


\section{THE CHERRY.}

Written for Bailes's "Cyclopedia of American Horticulture," by G. HARold PoweLL, and published on page 291 of same.

Cultivated tree cherries have probably sprung from the European species, Prunus arium Linn., and Prunus rerusus Linn. The domesticated forms of $P$. axinm are characterized by a tall, erect growth; reddish brown, glossy bark. which separates in rings: flowers generally in clusters on lateral spurs, appearing with the limp, gradually taper-pointed leaves; fruit red, yellow, or black, generally sweet, spherical, heart-shaped or pointed; flesh soft or firm. Sour cherries are low-headed and spreading; flowers in clusters from lateral buds, appearing before the hard, stiff, rather abruptly pointed, light or grayish green leaves. The following is the latest classification. (Bailey, Bulletin No. 98, Cornell Exp. Sta.)

Prunus arium has four representatives in the United States: (1) The Mazzards, or inferior seedlings ; fruit of various shapes and colors; common along roadside. In the middle Atlantic states the wild Mazzird trees often attain great age and size, particularly in the Delaware-Chesapeake peninsula. (2) The HEARTS, or heart-shaped, sweet cherries, light or dark, represented by Black Tartarian and Govermor Wood. (3) The Biciarreaus, or heart-shaped, firm-fieshed, sweet cherries, like the Napoleon and Windsor. (4) The Dures; light-colored, somewhat acid flesh, such as May Duke and Reine Hortense.

From Prunus cerasus two classes have sprung: (1) The AnsRELLES, or light-colored sour cherries, with colorless juice, represented by Early Richmond and Montmorency. (2) The Morellos, or darkcolored sour cherries, with dark-colored juice, like the English Morello and Louis Philippe.

The following species also have horticultural value: P'mmes mahalel, an old-world type, hardier and smaller, on which other cherries are largely worked. $P$. pemsigleanira, the native wild red, pin or bird-cherry, whose hardiness may adapt it as a stock for the plains states. P. besseyi and $P$. pumila, the native sand or dwarf cherries, the former represented by the Improved Dwarf Rocky Mountain cherry.

The cherry is not cultivated as a leading industry east of the Rocky mountains, excepting in western New York, where the sour varieties are grown for canning. The sweet cherry is confined mostly to dooryard and fence-corner plantings. Sour kinds are found in orchard blocks in New York, New Jersey, Pennsylvania, Ohio, Michigan, Indiana, Illinois, Kansas, and Nebraska. Sweet-cherry culture, how- 
erer, is adapted to the states between the thirty-ninth and fortyforth degrees of latitude and the sixty-eighth and eighty-sixth degrees of longitude [this area is not in Kansas], and to contiguous areas having similar climatic conditions. Spontaneous forms of it attain great size on the Chesapeake peninsula. The sour cherry may be grown with profit between the thirty-fifth and fourth-fifth degrees of latitude and the sixty-eighth and one hundredth degrees of longitude [five-sevenths of Kansas is within this area]. The Mazzard is the best stock for both sweet and sour cherries in the East. The Mahaleb is more widely used for the sour kinds, however, as it is easier to bud, and it is free from leaf-blight in the nursery. The Mazzard forms a better root system, stronger union, a longer-lived tree, and is sufficiently hardy. For the plains states the hardier Mahaleb stocks should be used.

The cherry likes an elevated, naturally light, dry, loamy, retentive soil. The sour kinds need more moisture, and will thrive in heavier land. A soil not naturally dry may be corrected by underdraining, and on light, dry knolls the moisture eapacity may be increased by green manures and surface tillage. The sweet cherries should be set twenty-eight feet to thirty feet apart each way; the sour kinds, from sixteen to eighteen feet. The trees are generally set at two years from the bud. The sweet kinds are started with three to five arms, with no central leader, about three and one-half feet high, and the branches are pruned to side buds for a few years to induce spreading, rather than a spike-like form. The top of a sour cherry is made like that of a peach tree. Plow the cherry orchard lightly in the early spring, and cultivate it every ten days, or after every rain, till the middle of June or the 1st of July. Seed at the last cultivation with a winter cover crop. Stimulate the trees with leguminous cover crops when needed; but the sweet cherry is a gross feeder and a rapid grower, and undue stimulation must be avoided. Keep the orchard in sod and pasture it with sheep, along the southern and western limits of profitable sweet cherry culture, and withhold nitrogenous manures.

Nitrogen, potash and phosphoric acid are the three essential fertilizers. Nitrogen may be supplied in leguminous crops; potash as muriate, at 150 pounds to 300 pounds; and phosphoric acid in dissolved rock, at 300 pounds to 500 pounds per acre.

Cherries should be picked by the stem in small baskets a few days before ripe. Sort out all stemless, small and imperfect fruits. Face the perfect cherries in small, attractive boxes or baskets, and pack these in small cases or crates. The choicer the fruit the more strikingly it should be displayed. Guard against breaking the fruit spurs in picking the sweet cherries. Fruit for canning is less laboriously 
packed, but may [should] be as carefully picked. The profits depend on the varieties and markets, but largely on the personality of the grower, and on his skill as a salesman. The range of profit for the sour cherry is from $\$ 30$ to $\$ 100$ per acre, and from $\$ .50$ to $\$ 300$ or more for the sweet.

The varieties adapt themselves to a wide range of territory. An imperative need, however, is the development of varieties with striking features for local adaptation. In the prairie states in the extreme north the hardier Amarelles and Morellos comprise the profitable kinds. Formerly the dark-colored, more acid Morellos were most sought after; now the milder Amarelles are demanded by both canners and consumers. In the following lists the varieties are named more for the purpose of illustrating the different types than for recommending specific rarieties. Anong Amarelles the Early Richmond and Montmorency are the leading types.

Early Richmond: Size medium; pit large; light red; poor quality : vigorous growth. Ripens June 20 in New York.

Nontmorency: Large, broad, flattened; pit modium: light red; flesh nearly colorless; juice moderately sour; rigorous growth; generally productive. Two weeks after Early Richmond. Most valuable Amarelle for the east.

Among the Morellos, Ostheim, Louis Philippe and English Morello are important types.

Ostheim : Dark red: roundish, flesh dark, tender, juice mild, dark : productive, hardy; growth slender. A week after Early Richmond, smaller. Too early for the East. [One of the best for Kansas. Keeps well after picking.]

Louis Philippe: Size of M[ontmorency, and ripens with it; round ; acid; skin and Hesh dark. Rather shy bearer in the East, but valuable in the TVest.

English Morello: Two weeks later than Montmorency : more open. drooping habit; fruit medium; roundish: red-black; very sour: slightly astringent: Hesh and juice dark, purplish crimson.

Among the sweet cherries, the firm-fleshed red or black Bigarreaus are the most profitable. The light Bigarreaus and Hearts are more susceptible to the fruit rot, and sell less readily. Representative types of Heart and light Bigarreau cherries are the following:

Black Tartarian: The most valuable Heart cherry : productive, vigorous, hardy, early: large, dark red or black; flesh dark purplish: very juicy, sweet.

Napoleon: One of the best light Bigarreaus. Fruit large; flesh hard, brittle, colorless; light lemon yellow, with reddish cheek; heavy bearer; rots if not picked before ripe; splits in wet weather. A week before Black Tartarian. 
From the dark Bigarreau the following are among the best types:

Robert's Red Heart: Bright, dark red, with an under mottling; as large as Napoleon; flesh pinkish; juice nearly colorless, subacid; heavy, regular bearer in Hudson river valley. Ripens with Napoleon.

Mezel: Large, heart-shaped, obtuse, flattened at both sides; uneven skin, dark red to black; firm, but heart-like; juicy; very sweet, stem long and tortuous; heavy bearer locally. Ripens with Napoleon.

Windsor: Large, roundish-oblong, firm, juicy; mottled dark red; Hesh pinkish white; stem medium, set in a slight broad depression; heavy bearer, vigorous, upright. Ripens two weeks after Napoleon. Very profitable.

Dikeman: Large, heart-shaped, obtuse, flattened on one side; black, with extremely firm reddish flesh: subacid, reddish juice; stem medium, in a slight broad depression : vigorous. Ripens three weeks or more after Windsor. A variety of great value.

DISEASES AN̉D INSECTS.

The brown rot (Monilia fructigena), which attacks the fruit at the ripening period, and particularly during sultry weather, can be largely avoided by picking the fruit a few days before ripe. It may also fatally attack the flowers, leaves, and twigs. In localities where the cherry blooms but does not fruit, the trees should be sprayed with Bordeaux mixture before the buds unfold, again when the fruit is set, and two or three times thereafter, with a colorless fungicide.

Black-knot, (Plomrightia morbosa Sacc.) [See elsemhere in this book.]

Leaf-blight (Cylindirosporium padi Karst). [See elsewhere in this book.]

Powdery mildew (Podosphara oxycantha De Bray). Often severe in the sour cherry, but can be checked by thorough applications of a fungicide.

The aphis (Nyzus cerasi Linn.) appears in the early part of the season on the young shoots, the leaves, the stems, and less frequently on the body or the fruit of the sweet cherries. It excretes honey-dew abundantly. The leaves curl upward and inward. Spray with kerosene emulsion, one part to sixteen of water, or with fish-oil soap, one pound to six gallons of water, before the leaves curl.

The curculio (Conotrachelus nenuphar). [See elsewhere in this book.]

Climatic injuries.-- Sun-scald and bursting of the bark. The sweet cherry is liable to a fatal injury from sun-scald in the South and prairie states. The trouble occurs in the spring, when the rays of the sun cause alternate freezing and thawing of the growing tissues on the south and west sides. In these localities, the bark of the tree 
frequently bursts open, and large quantities of gum exude. A rich garden loam, a summer drought followed by rain, excessive wood stimulation, violent changes of temperature in the winter, or other factors unfavorable to the maturing of the wood, aggravate the difficulty. The bursting of the bark is probably caused by the freezing and thawing of the tissues under these unfavorable conditions. Both troubles are more injurious to trees with exposed trunks. A low-headed and spreading top, soils not too rich, and cultural methods which fitvor the early maturity of the wood, lessen the danger. The trunks may also be protected by a board, matting or screen of some kind on the sunny side during the spring months.

(Written for Bailey's "Cyclopedia of American Horticulture," by EdwARD J. WICksoN, and published on page 293 of same.)

The Cherry in California.-In commercial importance, the cherry is least of the fruits of the temperate zone grown in C'alifornia on a commercial scale. This is not because the finest cherries cannot be grown, but because the avenues for the disposition of the product are not as wide as for other leading fruits. Recently there are indications that these avenues will be widened, for last year (1898) about 300 car-loads were profitably shipped in a fresh state to Eastern markets, and a product of 500,000 cases of camned cherries was disposed of to advantage; but until it is demonstrated that such distant demands will increase, present plantations will not be largely extended.

Cherries are costly in picking and packing, and to incur the chances of a local market, oversupplied whenever the trees do their full duty. the grower does not enjoy. Cherry drying has never seemed warrinted on a large scale, because of the large amount of labor required to the pound of product; and the grower has had no recuurse when the canner and local consumer will only pay the cost of picking and boxing. A good shipping demand seems, therefore, to measure the extension of California's cherry interest, and the early ripening of the fruit, which permits its sale cluring the blooming season of Eastern cherry trees, is the learling surety of such demand. On several occasions early varieties have been shipped from the Vacaville district overland. on March :31, but the usual opening date is about two weeks later, and thence onward later varieties, and from later regions, may be shipped until July, if found profitable. But, though there is plenty of good land upon which to multiply the present total of half a million trees. the cherry regions of California are restricted. It is one of the most exacting of all trees, and is only profitable when its requirements are respected.

About one-half of the present acreage lies in valleys opening upon 
the Bay of San Francisco, where deep and moist but well-drained alluvial soil fosters strong and sound root growth, and modified atmospheric aridity favors leaf and fruiting. On similar deep and moist soils, however, the tree enters the hot interior valleys to certain limits, chiefly along the river bottoms. It abhors dry plains. In dry air it usually refuses to fruit, although, if the soil be moist, it may make a stalwart tree growth. In foot-hill valleys it sometimes does admirably, both in growth and fruiting, and in mountain valleys, above an elevation of 2000 feet, on good soil, and in greater rainfall, and even with the snow flurries, which are experienced every year at proper elevation, the trees become very thrifty and profitable to the limits of local markets. The tree seems to have no geographical limitations in California; wherever suitable soil and weather conditions occur it accepts the situation - the Dukes and Morrellos succeeding under conditions too trying for the Hearts and Bigarreaus, but the latter comprise all the varieties that are of commercial account.

Cherry trees are grown by budding upon Mazzard and Mahaleb seedlings - the latter chiefly imported. It is customary to plant out in orchards at the end of the first year's growth from the bud, though two-year-old cherry trees can be more successfully handled than other two-year-olds. The trees are headed at one to two feet from the ground. cut back to promote low branching for two years, and then allowed to make long branches, and not usually shortened in, so long as thrifty and healthy. The tree, in a good environment, is, however, a very hardy tree, and will endure pruning to almost any degree. We have many trees which have made a very broad but not usually high growth, bearing 1000 pounds of fruit to the tree, and a few others which have even doubled that figure, while others have been dwarfed and trained en espalier. The commercial orchards are, however, uniformly of low trees, approximately of vase form in exterior outline, and with branches curving outward without shortening.

The cherry is very readily grafted over by the usual top-grafting methods, and large orchards have been thus transformed into varieties more acceptable for camning or shipping. Comparatively few varieties are grown. Early Purple Guigne, Guigne Marbre, and Knight's Early Black are grown in early ripening localities. Black Tartarian and Lewelling are the mainstay for black cherries. The Napoleon Bigarreau (locally known as Royal Ann) is the ideal for a. white cherry, and almost excludes all others, though the Rockport Bigarreau has some stunding. Of all the varieties grown, the Black Tartarian and Napuleon Bigarreau constitute seventy per cent. of the crop and probably ninety per cent. of the amount marketed.

California-grown cherries attain large size; the canner's require- 
ment for fancy fruit is a diameter not less than seven-eighths of an inch, and for No. 1, not less than three-fourths of an inch. Wholesale prices usually range from $\$ 40$ to $\$ 60$ per ton for black and $\$ 80$ to $\$ 120$ for white, but this year (1899) canners have paid as high as $\$ 160$ per ton for white cherries. The higher rates can only be expected during years of short crops.

\section{A KANSAS CHERRY-THE BALDWIN. (see molored plate.)}

$\mathrm{By}$ its Discoverer.

The original was planted in the spring of 1888 in an orchard at Seneca, Kan., for an Early Richmond cherry, which had been burlded on a common Morello seedling. The budded part was accidentally broken off and a sprout came from the root which seemed so vigorous that it was left to grow. It proved to be such a rank grower that it soon attracted attention, and when it fruited, which was the fourth year, it showed so much finer, larger and better fruit than any other, that the small boys always sought it out from anong several hundred cherry trees of various sorts. The tree is an upright, vigorous grower, forming a round head: leaves large and broad; bloom pure white, changing to pink: fruit large, almost round, very darh, transparent wine color; Havor slightly acid, yet the sweetest and richest of the Morello type; stems rather large, of medium length, and generally in pairs. Unexcelled in earliness, vigor, hardiness. quality and productiveness. Out of 800 trees it readily attracts attention as being the most thrifty and beautiful.

It fruited four years, and each year seemed to be so uniform in size, productiveness and earliness, that I decided to give it a name and propagate from it. It was first named the "Kansas Queen," but on account of it being against the rules of the American Pomological Society to give compound names to new fruits, and upon the suggestion of W. F. Hiekes, of Huntsville, Ala., who became interested in it, it was named "Baldwin." since then I have gathered fruit from it every year.

The unprecedented severe cold weather of the winter of 1898-'y9) fully tested its endurance and hardiness. All Baldwin cherry trees came through in the best of condition, with perfect buds, more vigor'ous and thrifty than English Morello, Early Richmond or Montmorency in same orchard under same conditions, and while old varieties show forty per cent. of dearl trees and only half a crop of fruit, the original Baldwin tree was loaded with fruit, and 200 Baldwin trees planted in orchard in spring of 1898 show only a loss of four per cent. 
This proves by its tested hardiness, its extreme productiveness, taken in consideration with its large size, beautiful shape, and most delicious quality, together with its superior shipping qualities, that it is ahead [for the West] of any other cherry known. The fruit ripened this year (1900) June 17, and was loaded, as usual.

Mr. S. J. Baldwin, Seneea, Kan.:

Oregon, Mo., July 22, 1898.

Dear Sir - The samples of Baldwin cherry sent me by mail last month came in nice condition, and on examination I found them to be a large, beautiful Morello, of very firm flesh and good quality. I regard it as superior to any of the old varieties; and if it is an abundant bearer it will certainly prove a great acquisition to our list of Morello cherries. Yours truly, N. F. Murray, President Missouri State Horticultural Society.

Davenport, Iowa, July 22, 1898.

DEAR Sir-The Baldwin cherry arrived in fine condition, and is a much better cherry than English Morello.

Nichols \& Lorton.

DEAR Sir-Accept my thanks for the Baldwin cherry. They are surely a superior Morello. I will be very pleased to try a few trees here.
I am, yours,
E. W. M. Kirkpatrick, McKinney, T'ex.

DeAr SrR-Having eaten fruit from your Baldwin cherry tree, I am free to testify to its superior quality, large size, beautiful color and shape. I consider it a great acquisition to our cherry list, and far better than any Morello cherry I have ever seen, and, as it is about three weeks earlier, I think it should be planted largely; it will certainly be profitable as a commercial cherry. The tree is a very healthy, vigorous grower, being fully one-third larger than other cherry treès of same age.

G. W. Johnson, Seneca, Kan.

\section{THE CHERRY.}

From "Fruit Manual," a work published in 1886 by the State Horticultural Society of Kansas.

This fruit has become a general favorite throughout the state. Its easy culture, hardiness and productiveness, and the value of its fruit fur general uses, have caused a large planting in Kansas. It thrives quite well on either high or low linds, and on sandy and loamy soils. The ALorello family is highly successful wherever planted, and emhraces the sour varieties - Early Richmond, Kentish, Montmorency, English Murello, and common red (black) Morello. In some localities the finer flavored varieties - as May Duke, Governor Wood, Royal Duke, Belle Magnifique, Belle de Choisy, Reine Hortense - are quite successful. The class known as "sweet varieties" do not succeed. The tree often becomus fatally injured by the intense heat of summer and the extremes of winter weather.

The main requisites in successful culture are deeply prepared and enriched land, where not so by nature, and a vigorous wood growth. Whenever a tree becomes stunted by neglect or from sterility of the 
land decay soon sets in at the heart, and death generally follows in a few years.

This, as well as all classes of soft fruits, should he as near the dwelling as practicable, for convenience in gathering the fruit and general care of the trees.

High lands are preferable, as the fruit-buds are less liable to be? injured by spring frosts, and the tree maintains a normal condition better through rarying weather in winter, and better facilities are afforded for circulation of the currents of air during extreme rainfalls and sudden changes in temperature.

An eastern or northern slope is preferable, as trees do not suffer so much from droughts or heat of sun, and should be sufficiently inclined to drain off any sudden, heavy rainfall, as a retention of a surplus amount in the land will weaken the vigor of trees, and endangers their lives.

A deep loam and a sandy soil are to be preferred; but other soils can be made suitable by deep tillage and manuring, and for arid lands a heavy mulching.

When planted on flat lands drains must be provided; but on slopes water is seldom retained in amount detrimental to the trees. This is forcibly impressed on the grower when heavy and continuous rains flood the land at the ripening period, which is followed with cracking and bursting of the fruit, rendering almost the entire crop unmarketable.

On open prairie windbreaks are an advantage, when on the south side only.

Deep plowing and pulverizing of the surface and stirring of the subsoil are as much needed with the cherry as any fruit. Sterile lands must be well enriched with barn-yard litter, wood ashes, or any well-rotted vegetable matter.

The trees should never be over two years old; strong, vigorous, and well rooted. A second-class tree is never cheap, and its use is questionable economy; better plant fewer of the first class, at same cost. Of stock there are three kinds, viz., Mahaleb, Mazzard, and common Morello. Mahaleb is short-lived, Mazzard not always hardy, and Morello sprouts from the root. The preference of the Society has been towards Morello as preferable, claiming early and profuse fruiting and hardiness.

The holes, experience in Kansas has demonstrated, need not be any larger than is necessary to receive the roots when spread out naturally, and deep enough to set the tree about as deep as it grew in the nursery. In light, sandy soil it may be some deeper, but not in clay or heavy soil. Several of our members have for the past ten years been 
planting their orchards in the following manner, and we consider it as having more advantages than any yet recommended: First, procure a half-dozen or more stakes, four or five feet high; set these stakes in line where you want the south row of trees; then, with a steady team, plow and mark out a straight furrow in range with the stakes; have a man follow after and measure the distance for the next row to the north, and set the stakes, then mark out as for the first row; and so on until the north side of the plat is reached. Now set the stakes north and south one foot east of where the east row of trees is wanted. Begin at the sonth end, and mark out a furrow in line with the stakes, throwing the furrow to the east; then turn back, letting the near horse walk in the furrow; run another furrow parallel with the first one, and about twenty inches west of it; make one more romna, and throw out the center, thereby making a dead furrow where the first row of trees is to stand. Use a good, stout team and have a dead furrow running north and south where the rows of trees are to stand, twenty to twenty-four inches wide and eight to ten inches deep, which is about the right depth. Go along with a shovel and throw out any loose dirt that may have fallen hack where the east-and-west marks cross, where the trees are to stand.

The cherry tree is a close grower, requiring little room, forming either an upright or low, round head, according to varieties. For convenience in cultivation, the rows should be twenty feet apart, and trees fifteen feet in the row.

Many trees fail because planted too late in the spring, and many more fail because planted in the fall. The safest time is in the spring, as soon as the winter's frost has left the ground. Let one man take a tree, set it in the dead furrow, where the east-and-west marks cross, spreading the roots in natural shape; another throws on a few shovelfuls of well-pulverized surface-soil, seeing that this is well worked around the roots; then let the one holding the tree tramp the soil well around it while the other fills, till the earth is about level with the surface. Lean to the southwest. It is best to plant the trees of each variety together [?].

The first summer after planting is a critical time and the trees should receive great care. Keep clean and cultivate well. Provide doubletree not over twenty. five to thirty inches long, and singletrees not over sixteen or eighteen inches, and when cultivating always use them. With care there is no need of barking. If planted in dead furrows, soon close up the dead furrows with a plow. In eight or ten days plow the ground again, throwing a furrow to the trees, not more than two or three inches deep, about four rounds to each row. Repeat three or four times during the season, or as often 
as the weeds start, rumning a little deeper each time. This gradually deepens the earth around the trees as the season advances, and by fall we have a deep, mellow bed eight feet wide and quite deep. All weeds not covered by the plow should be cut out with a hoe. On the ground between the rows plant crops that require cultivation, such as corn, potatoes, beans, etc. Corn is best, as it receives cultivation when the trees need it, and affords some protection from wind. The second year throw furrows from the trees, and next to them, and so on, keeping the ground clean and well stirred till the middle of July, when culti. vation should cease for the season. Stirring the ground later than this stimulates fall growth. which does not have time to ripen well, and is liable to winter-kill. The third, fourth and fifth years cultivate as the second, and if the trees have been well cared for they will have become well established in fruiting. After this, if cultivation is not continued, the land should have each year a liberal dressing of stable litter. Cherry trees must be kept in a vigorous, growing condition, and if varieties adapted to our climate are used there will be but few failures.

It is generally conceded that pruning is a necessity, the question being as to the extent. The points are: First, a low and uniformly shaped head; second, to facilitate the penetration of light and air to the inner portions of the head; third, to encourage and direct annual growth to form a shade sufficient to break the force of the sun's intense heat upon the branches and trunk of the tree; fourth, to remove all chafing, straggling and succulent growth. It should be done mainly while the tree is young, and in the spring before the buds break into leaves. Succulent growth should be removed as it appears.

Convenient ladders are found at almost any store dealing in hardware or implements. As the trees become large and tall, the staging platform is better. To construct this, two wooden horses are made of a convenient height, and placed at safe distances apart along the sides under the branches of the trees, and on their tops is constructed a platform where one or more pickers may stand and work. These will accommodate several pickers at a time, are movable, and easily shifted from place to place.

A crate, made of light but strong material, and of a size to receive four common berry boxes, is suspended to the picker, adjusted to a convenient position in front of him, relieving both hands for picking.

A shanty or packing-room is convenient, and will also be found handy for storing the fruit and to shelter the pickers from a sudden rainfall. In this may be constructed a facing and packing-table.

If for shipping, the best time to gather will be when wholly of a light red color - approaching scarlet; if for a near market, a dark red. color. 
The picking fore should be divided into two sections. The first gathers all fruit within easy picking distance of the ground, and keeps in advance of the second section, which works from ladders or staging, and cleans up all. Cherries must be picked by the stem, and not by taking hold of the fruit, and care must be taken not to even start the stem from the fruit, as the juices will flow out, and such fruit quickly spoils. None but sound, ripe specimens should be placed in the boxes, and the top layer in every box should be an honest index of the whole. With the picking crate swung to the picker, he can easily do his work well, and quickly detect any damaged or inferior fruit before it is picked. As soon as the boxes in the picking crate are filled they are taken out and placed in a shipping crate, and others put in their place, and the crate when full carried to the facing table.

Packing.-Facing consists in turning the stems of the top layer down, which gives the appearance of a solid surface. Boxes should be filled a little above their edges, to avoid the semblance of stinted measure, and provide for the inevitable settling sure to follow the jarring of transportation. Pack in twenty-four-box crates, close up securely, brand with name of variety and name of grower and consignee, and send to destination at once. This fruit is never so attractive as when first taken from the tree, and the sooner it is in the market the more readily it will sell. The practice of facing is receiving severe criticism, as offering too great temptation to dishonest conduct. [ This book is for Kansans, not for "dishonest people."]

Cherries can be safely held in a cold storage for several days, but must be quickly used when taken out; this is an advantage to the grower when the market is overstocked.

\section{CHERRY GROWING FOR PROFIT.}

A paper read before the Southwestern Iowa Horticultural Society, by J. G. BERRYHILL, of Des Moines.

The fruit-growers of Iowa are interested in the growing of varieties that are generally known as the "sour cherries," but are more properly called the Morellos. There has been some experimenting in the growing of the sweet cherries and of the Duke varieties, all of which have, I believe, been unsuccessful, although some of the Dukes have been grown in southern Iowa, and have borne more or less sparingly. The trees and fruit-buds are subject to winter-killing. It is claimed that certain varieties of sweet cherries, introduced by Prof. J. L. Budd, of the Iowa Agricultural College, from eastern Europe and western Asia, can be grown successfully in this latitude. I am, 
myself, experimenting in growing the Orel Sweet, the Vilna Sweet. and the Yellow Glass. The first two, judging from the appearance of the trees and leaves, are of the Duke family, and the Yellow Glass evidently belongs to the Bigarreau. The Vilna Sweet has fruited in the vicinity of Des Moines, and, while it bears more or less sparingly, the fruit is of such superior quality as to justify its culture for home use. The Orel Sweet is a beautiful tree, but is, I fear, tender in fruitbud, in view of the fact that the buds swell under the influence of abnormal heat in the fall, and the buds being thereby exposed to winter injury.

Prof. L. H. Bailey, of Cornell University, New York, divides the sour cherries into two classes, the Amarelles, with uncolored juice, and the Morellos, with colored juice. The first division is represented by the Early Richmond, and the second by the English Morello. Successful growing of these sour or Morello cherries in the West is limited to a territory about 500 miles in width, commencing in the latitude of St. Lonis on the south, and extending to the line of the Chicago \& Northwestern railroad, in Iowa, north.

This limit, it is probable, will be extended a degree or two further north by the intruduction of the Russian varieties, many of which have already been satisfactorily tested in and north of the territory referred to.

The varieties of the cherry with uncolored juice adapted to the latitude of the south half of Iowa are as follows:

First, the Early Richmond, which may be regarded as the standard cherry of this territory, the same having been introduced with the earliest settlements, and now extensively grown in a wide extent of territory in the Northwest. The tree and fruit are so familiar to every one that further lescription is unnecessary. It is to-day the most reliable known cherry for this section of the country.

Second, the Dyehonse, grown by Mr. H. A. Terry, of Crescent. Pottawatomie county, Iowa, for the last thirty years. The tree is a more spreading grower than the Early Richmond. It is a fair bearer of fruit, very similar in appearance to the Early Richmond, possibly a little larger in size, a little deeper in color, and of about the same quality, and ripening a few days earlier.

Third, the Late Richmond, similar to the Early Richmond in appearance. The tree is rather an erect grower, and the fruit ripens about two weeks later than the Early Richmond. It is a little smaller in size, but is most excellent in quality. I have two trees growing on my farm, near Des Moines, over twenty years old. These trees have grown seven good crops during the seven years I have owned the place, and I have been led to propagate from them by reason of the 
good quality of the fruit, and the good bearing quality of the tree. I understand that the Late Richmond, as it is known in many portions of the state of Iowa, has the reputation of being a very poor bearer. 'This criticism, however, cannot be raised against the Late Richmond, as grown by me.

The most beautiful of cherries with uncolored juice, and the most popular in the market, is the Montmorency. It should be called the Montmorency Ordinaire. The tree is an erect and symmetrical grower. The leaves are larger than those of the Early Richmond and the rarieties above named. The fruit is long stemmed, a little flattened, much larger than the Early Richmond, and superior to that fruit in quality. I belive that this variety is grown in western Iowa and eastern Nebraska as the Large Montmorency. I have trees of the western Iowa variety growing side by side with the Montmorency Ordinaire, secured from Cornell University, New York, and the two cannot be distinglished. I believe that the western Iowa variety is improperly named the Large Montmorency, which is a distinct variety much inferior to the Ordinaire in bearing quality and size of fruit.

The cherries with colored juice are represented by the following varieties:

The English Morello.-The tree is dwarf in habit, the fruit large and somewhat heart-shaped, and very dark and beautiful in appearance, but exceedingly sour. This variety is very prolific, and is a popular market sort. The tree, however, is short-lived. It is claimed that this variety, and all of those with colored juice, should be grown on Mazzard stock, as distinguished from the Mahaleb, and that on the Mazzard the tree will live a much longer time, as well as be more prolific.

The Wragg is very similar to the English Morello in appearance, but it is exceedingly sour. The tree is a dwarf grower and very prolific. It is claimed that this variety is identical with the English Morello. As grown by me I think it can readily be distinguished from the English Morello, both in habit of tree and in flavor of fruit.

A third variety of the dark cherries, now grown more or less extensively throughout the Northwest, is the Cerise d'Osthiem. The tree is somewhat dwarfish in habit, the leaves have a peculiar heart-shaped form, and the branches are pendent. The variety is quite prolific. The fruit is quite dark, with dark juice, and is rery much sweeter than the English Morello. A number of varieties of the Ostheim family have been planted in this country, but the one referred to is the best of the family. It was included in the Russian importations of Prof. J. L. Budd, of the Iowa Agricultural College. These Russian varieties are now being tested quite generally throughout the Northwest, and 
are indorsed by many growers as superior to the Early Richmond and the English Morello.

Among the varieties that give promise of sucess, I mention the Orel, Sklanka, King's Amarelle, Lutovka, and the Terry, which was named by the Iowa Horticultural Society at its meeting in 1896. This variety was received by $\mathrm{H}$. A. Terry, of Crescent, Pottawatomie county, Iowa, with other Russians from Professor Budd, twelve or thirteen years ago, but was improperly named. He called it for some years the Early Morello. Professor Budd, at the 1897 meeting of the Iowa Horficultural Society, expressed the opinion that this variety wis the Bouquet Morello. Mr. Terry claims that it is the finest variety, taking everything into consideration, that has been raiserl in Iowa. It, together with the Russian varieties above mentioned, has light juice. The tree which I am now growing is a rery erect srower, and gives evidence of great hardness and fertility. I have not fruited it.

Among the Russians with colored juice may be mentioned the spate Amarelle, Schatten Amarelle, Double Natte, Bruesler Braun, Brussarbian, and the Criotte dn Nord. Of these, the Schatten Ameralle has been grown by Mr. Hinliley, of Marcus, Cherokee county. Iowa, and is pronounced by him to be hardy and prolific. The Double Natte has been grown by Mr. Terry and by Mr. Coleman, on the latter's farm in Arlams county, and is regarded by both as of very superior quality. The Brnesler Bram is a fair bearer of fruit much larger than the Montmorency, very rich and almost sweet when thoroughly ripe. I regard it as a very valuable cherry for home use, and it may prove valuable for commercial growing.

Among other varicties grown in the Northwest I can mention the Early Morello, a chance tree grown by the late David Reed in his orehard in Gage county, Nebraska. This cherry is a strong grower, and the fruit, which has light juice, ripens a week or ten days earlier than Early Richmond, and is pronounced by those who have grown it as of good quality. The Early Morello grown in the vicinity of Kansas City is a black cherry of the Morello type, imported by the late A. Sauer. of Rosedale, Kan, from Erfurt, Germany, about twenty years ago. This Early Morello has been pronounced the Black Morello, and is highly commended hy those who have grown it, and is claimed to be a week earlier in ripening than the Early Richmond.

The ()stheiner Weichsel, also an importation of Mr. Sancr, has been grown in the vicinity of Kansas City for twenty years, and is pronouncer by competent horticulturists the finest variety grown in that vicinity. I am inclined to think that it is from the same fumily as the Cerise d'Ostheim. I have trees of both of these varieties, as also of the Early Morello of Nebraska, and will be able to form an opinion as to their merits in the course of time. 
Cherries should be planted upon well-drained soil, such as is suitable for the growing of cereal crops, in rows about twenty feet apart, rumning north and south, with the trees fifteen feet apart in the row. They should be cultivated from the earliest time in the spring until about the 1st of August, and no other crop should be grown in the orchard. I believe that continuous cultivation from early spring to late summer will produce very much better results than can be secured by seeding down the orchard to clover, although it is probable that benefits may be secured by sowing clover and turning the same under to restore nitrogen to the soil. When the trees commence to bear the fertility of the sril should be restored by dressing with manure, potash, and phosphoric acid fertilizers. The trees should never be pruned except at the time of planting, when the roots should be cut back and at least two thirds of the last year's growth removed from the top. If cultivation is continued late in the fall, growth is continued late in the season without maturing the wood and buds, rendering winter injury thereto probable.

The cherry will begin to bear four years after planting, and will bear a reasunably profitable crop at the age of six years. None of the varieties usually planted are long-lived. In view of the fact that cultivation has been rarely practiced in the past, I am led to hope that the longevity of the tree may be greatly extended by the treatment herein recommended. It is my opinion that the greatest success in raising the cherry in the Northwest can be secured in the latitude of the south half of Iowa. I have noticed that in the vicinity of St. Louis the intense heat of the late fall frequently causes swelling of the buds, which are thereby exposed to winter injury, and understand that in south central Missouri this is the cause of the frequent failure of crops.

\section{THE CALTFORNIA CHERRY.}

Probably no fruit grown in California is received by consumers with greater genuine pleasure than the cherry. The cherry is not adapted to all parts of the state. The portions which produce lemons and oranges fail to produce cherries. They require a deep sediment soil and a climate not too hot. Santa Clara Valley is probably the largest and best cherry district in the state, including in this district the section on the east side of the bay on both sides of Haywards. Chico has some good cherry orchards, and the largest cherry tree in the state, so far as known. is on the American river above Sacramento. Vacaville and Winters are in a section noted for shipping very early cherries, the first box generally going out in April. 
Very early varieties are grown for these early shipments, such as the Early Purple Guigne, Belle d 'Orleans, Knight's Early Black, etc. These sorts are all inferior in quality to the later kinds, but being early command the high prices of the first market.

The most popular eating cherry is the Black Tartarian, well known. The Governor Wood, Yellow Spanish, Cleveland Bigarrean and others are rather early white cherries, all too soft for successful shipping or canning. Ripening about with the Black Tartarian is the Centennial, a magnificent, firm-fleshed white cherry with a flame cheek. Its only fault is that it cracks on very slight provocation, such as a shower of rain or late irrigation. Black Republican is a late black cherry, very firm and an excellent shipper.

The very popular cherry of the state is the Napolean Bigarreau, or Royal Amn, as it is known to the trade. This is a white cherry with cheeks of solid color, very hard and firm, shipping well, and most popular with the canners. In large quantities this cherry brings the highest price of any sort. This cherry seems to do well in the mountains where other cherries fail. The Black Tartarian does not do well in the mountains, generally.

The Bing is a cherry first noted in Oregon and giving some promise where introduced in California.

On unsuitable soil the cherry tree does not flourish or bear. It gums, dies back, or proves barren, often to the great disappointment of the planter.

The cherry is shipped to all the California cities and to southern California, and on to the east to Chicago, Boston, New York, Philadelphia, and all important markets.

The first box usually brings a round ten dollars, and the first few hundred boxes rather fancy prices, and then the price goes according to supply and demand, and the condition in which they are received. During the great railroad strike cars of cherries stood in San Jose depot for a full month well iced, and were then opened and the fruit sold here at fair prices.

One of the best orchards in the state is located near Sam Jose, the property of Mrs. IT. Geiger. It was planted by her husband about twenty years ago and has a deep sediment soil. It is thoroughly irrigated in the winter or late spring and again in summer after the crop is off. It consists of about twelve acres, principally of the Black Tartarian and Royal Ann varieties.

For many years it was contracted for five-year terms by a very popular shipper, who made much of his reputation by the good quality of the cherries of this orchard. When the contracts expired after the death of Mr. Geiger they were not renewed, and the fruit was 
shipped direct from the orchard under the management of W. R. Geiger, a son. Since the death of her son Mrs. Geiger has herself managed the orchard and directed the cultivation, harvesting, packing and shipping with great success.

She has trusted help in all departments which she secures year after year.

Men with long ladders, tin picking buckets and hooks gather the cherries from the trees. The fruit is then taken to a large packingshed, and young ladies pack carefully in shallow ten-pound boxes with ventilated tops and sides, and a partition across the middle to check any movement. The fruit is all packed in straight rows and layers, and a neatly packed box presents a beautiful appearance when opened. The great fruit wagons stand under the shed, and large loads are taken to the cars. Sometimes more than 1000 pounds of cherries are gathered from a tree in this orchard.

Cherries generally bring good prices. From four to eight cents per pound is about the range, and the income from a good cherry orchard is often from $\$ 500$ to $\$ 800$ and even $\$ 1000$ per acre, with a good crop and a good market.

\section{PRODUCTION OF CHERRIES.}

By E. F. Wetmore, before the East Tennessee Horticultural Society.

We have observed that nursery catalogues state that the cherry will thrive and bear almost anywhere so long as it is planted upon well-drained land. We note that it makes but little difference where these catalogues are published; whether north, south, east or westall are the same. Our opinion is that the cherry may grow almost anywhere, but to produce successful crops of fruit it has its preference of location and climate. In the extreme north the fruit-buds winter-kill; while south of the latitude of Tennessee the climate is too warm. Even here in this state we find that in some locations they are not productive. This, we believe, is usually the case where they are planted upon heavy red clay soil. Our observation has been that the cherry, where planted on sandy, loamy soil, especially if somewhat elevated, has proved more productive one year with another than on heavy clay soil.

I have a little orchard containing 360 trees, some of which have been planted four years, and some three years. I also have a few trees that have been set ten years. We have had cherries every year without a single exception for the past nine years, the quantity increasing each year with the growth of the trees, until last year, 1897, 
when some of the trees, planted then nine years, produced more than two bushels of perfect cherries, free from worms, and fit to set before a king. This year, 1898 , the crop was not increased above that of last year, but instead there was a light crop, due to severe freeezes, which occurred on April 4 and 5. Ice formed one-half inch thick and the mercury stood at twenty-two degrees. Nearly all varieties of cherries were in full bloom, and most of the fruit was destroyed.

To show the hardiness of cherries in comparison with other fruits, I will state that this freeze killed all the fruit in my peach orchard, and also the greater part of my apples. None of the sweet types stood the freeze well enough to produce fruit. I have planted in my test orchard the following varieties: May Duke, Large Montmorency, Early Richmond, Ostheim, Wragg, Large English Morello, Sudie. Windsor, Yellow Spanish, and Black Tartarian. The three last named are sweet or Bigarreau type All others bore, some trees quite full, while some only a few.

My elevation is 2300 feet above sea-level, and 1200 feet alove the Tennessee river. My soil is a sandy loam.

They should not be trimmed too high - three to three and a half feet is about right. They need very little or no trimming after the first two or three years. Do not form a crotch or forked tree, but an evenly balanced head. If any of your little trees are forked, either cherry or any other kind of fruit-trees, when they come from the mursery (though they should never be), you should cut off one of the limbs, and though it may not make a pleasing sight at the time, it will soon balance up all right.

\section{THE CHERRY.}

By S. H. Linton, Marcelino, Mo.

Practical horticulturists are anxious to have all rarieties of fruit come up to a standard. From a general view over the country, the cherry is crowded out by other fruits, because the cherry is less understond and therefore less appreciated. Striking a line east and west with the south line of Missouri and another line east and west alnmg the center of Iowa, between these lines, from the Atlantic to the Prcific coasts, Morello cherries give paying crops if planted in ground agreeable to their nature and given proper care. There are many localities within this area that do not produce cherries sufficient to supply their local market. This should not be the case with progressive fruit men. The cherry demands a dry clay soil. They are rather deep rooted and great feeders, and, if given too much humus, will take up 
food faster than the tree can digest it. The result is dyspepsia of the tree, and they will soon show the disease in what is called foot-rot. This disease starts in the stalk at the top of the ground and goes up and down. It is most prevalent during warm, wet weather in late spring and early summer. While most fruit-trees are more or less. liable to this disease it is the worst with the cherry. But if the cherry is planted on clay land with good drainage, and the tree is not crowded faster than the growth will nicely ripen, there will be but little trouble with foot-rot. The black-knot is troublesome in certain localities, but if care is used in not buying young trees already diseased, there is little fear of this trouble. The cherry is considered by some growers to be short-lived. Even if this be so, there are good profits in growing the cherry if it does not live over ten years. I know cherry orchards that have been in regular bearing ten to fifteen years, and still bid fair to produce many good crops yet.

As to varieties for profit, this depends upon the locality, but for the extreme east and west* of area given, the Duke and Morello, or the family of sour cherries, can only be successfully grown. Sweet cherries are more adapted to favorable localities in the mountain regions and further south. Horticulturists would be truly glad if sweet cherries could be successfully grown and fruited everywhere. Fruit-growers should encourage planting more of the cherry.

\section{NOTES ON CHERRY CULTURE.}

By S. H. Linton, Marceline, Mo.

The cherry fills a gap in the fruit supply that no other fruit can well take, in season or the culinary, the mild subacid flavor, toned with a peculiar agreeableness to the appetite, with a tonic so much desired to cool burning thirst during the hot summer days.

Cherries are divided into two families or groups, the Heart and Bigarreau, or the family of the sweet cherry. This includes all the white, yellow and some of the red and black varieties; all are very rich and high Havored. The Duke and Morello families include the more acirl varieties.

There are few more useful trees than the cherry. It may be planted as an ormamental tree, lining streets or avenues, giving touch to the beautiful in early spring, with its banks of snow. white bloom, after which the tree soon changes to red, like the "fiery bush" of old, enticing all to come and partake of its bountiful supply of luscious fruit.

*"Extreme east and west of area given" means on either coast, where sweet cherries grow in abundance.-SEC. 
The cherry can be grown successfully on any clay soil with a welldrained subsoil, and if mixed with gravel or shale is all the better. For a family supply it may be planted in the yard or lawn, in which case the ground should be worked around the trees as much as three or four feet the first two seasons after planting to keep down the growth of grass and weeds. This method is much preferred to mulching, as mulching adds humus, which stimulates growth faster than it can ripen its wood.

For a commercial purpose, the location should be selected with two points in view - first, that the entire plat is well drained; second, that the soil is not too full of humus, with a north and east exposure, and a west and north protection. In the absence of natural protection, plant evergreens or some spreading native forest-trees. Plow deep and harrow smooth. Mark off accurately, so as to place the trees twenty feet apart each way. If the surface of the land be level, plow with a back land for each row. Dig holes wide and deep enough to receive the roots without twisting or bending. Have the trees trenched handy, taking out a few, protecting the roots as taken out. Cut back all mutilated roots to sound live wood with a sharp knife; incline the stalk ten to fifteen degrees to the southwest. Set deep enough to bring the budded jumction two to three inches under the level of the ground. Fill in with well-pulverized soil, sprinkling on and through the roots. If the dirt is pitched in, a shovelful at a time, it will clog on top of the roots, leaving space underneath without any. Pack or settle the dirt as filled in until the roots are well covered, when the packing should be done with the foot, giving weight and force until satisfied that there are no air spaces left. Finish the filling with loose dirt on top without tramping; this will prevent the soil from baking and cracking. After the planting go over the entire tree cutting off broken limbs, but no other cutting should be done. If possible, before a rain, the cultivator should be run through the orchard, loosening up the ground that has necessarily been tramped and packed in planting.

If the ground is fertile the orchard may be planted to com, potatoes or any hoed or cultivated crop for first two seasons, and if overfertile crops should be grown up to the fourth season, when the ground can be sown to clover or left to grow in weeds. In either case the clover or weeds should be mowed from middle to last of June and again from micldle to last of August, and in both cases left on the ground. No pruning is required, except to cut out dead or broken limbs, and the best time to do this is at the moment you find the limb) dead or broken.

If planted twenty feet each way it takes 110 trees to the acre. The average yield of a cherry tree at five years old is nine gallons; which, 
at twenty-five cents per gallon would bring in round numbers, $\$ 247.50$ per acre. If planted on suitable ground, and given proper care, a cherry orchard can be depended upon for annual crops for ten to fifteen years.

\section{CHARACTER OF SOILS, LOCATION AND VARIETIES FOR A CHERRY ORCHARD.}

By J. J. KIser, Stanberry, Mo.

The character of the soil in northwest Missouri, for which alone I can speak, is preeminently a fruit soil; our subsoil - a deep stratum of from twenty to forty feet of porous joint-clay - can only be equaled if excelled by that formation known as the Missouri river bluff or loess formation. This joint-clay is in reality a soil in which, if brought to sunlight and properly aerated, will grow the finest plants. Add too and over this a layer of from six inches to six feet of vegetable decomposition, mixed with drift soils and sand, for ages forming a loam in which is every element of plant structure. The cherry tree will not live with its feet in standing water, neither ought anything but a willow be planted in such a place. My best growing and bearing trees are on the north side of the top of a small elevation, hardly to be called a hill, though trees are doing well on the south side of the same. Trees set near an artificial pond so that the high-water mark is on a level with the roots of trees, are dead or stunted; while plum trees in the same situation show very little if any damage. The largest and finest specimens of cherry trees the writer ever saw were planted along the upper sides of cuts in roadways and along terraces on mountains and hillsides in Switzerland - trees over two feet in diameter that looked as though they might be a century old.

VARIETIES.-I approach this part of my subject with some degree of hesitation. Differences of soil, climate, and even the markets, may modify the choice of varieties. One of my earliest recollections is a large cherry tree that stood near the homestead in the old "fatherland." How well I remember watching the first burst of bloom in the spring, the development of the fruit, even the counting of the specimens that some day I might reach, the seemingly slow growth, and then, one morning the red tinge on a few of them-how slowly they ripened. Yes, I will confess to putting some of them into my mouth without picking them from the tree - I believe I can taste them yet - and when they did get ripe, great, big, lusciously sweet; they were such as I never expect to see again, for they will not grow in this climate. When I tasted my first cherries this sicle the Atlantic I thought, oh! how is it possible to like such sour things? 
When in Kansas City a few years ago $I$ bought a box of California sweets (?); small affairs they were, but I took them in haste to get once more a realization of my youthful memory. I tried one, two; in surprise I looked at the rest. They all looked alike. Tried another; found that all three tasted alike, and in disgust I consigned the whole lot to the gutter.

But let no one understand that I do n't like cherries, even such as we grow in abundance in northwest Missouri. In getting my allegiance Americanized I have also got my cherry taste adjusted, and to-day I vote the American cherry a grand success. Fully ripe, they are good to eat; mixed with sweet apples, or any kind, for that matter, and sweetened to taste, they make the best pie on earth.

For a market cherry I would place the English Morello at the top of the list. True it went to wholesale destruction last winter; but are we going to quit planting all the kinds of fruit that were injured by that outlandish performance the weather clerk put on the program last winter? I think we will discharge him and the next one may take due notice and govern himself accordingly. Last winter has been called by some a test winter, but I do n't understand it so. It is not to be expected that so many adverse circuinstances and conditions will get up another such a combination in the next century.

The next best and very best for home and near-by market is Early Richmond. It must be used soon after picking. A neighbor told me that in camning they had mixed them with one-half strawberries, to the great improvement of both, the combination keeping well, when they had had tronble in keeping strawberries; that it gives a body and substance to that watery fruit that makes it much better. A few years ago I could not sell Early Richmond in my market. Nothing would do but English Morello. Yet to-day people have learned that the Early Richmond is much the better cherry and the demand has increased beyond the supply.

Montmorency Ordinaire, Suda Hardy and Ostheimer have gone to the happy hunting-grounds along with English Morello and some semi-sweets. True they are not all dead, but all more or less damaged; being late, they grew too late, and were not matured to withstand the shock. Dyehouse wintered well and bore a small crop; it does not bear as young as Early Richmond: may do better later. I can see very little difference in fruit, though the trees grow more stocky. Wragg has stood the weather finely; it is small, sour, bitter, and puckery; even sugar fails to make it eatable; not adapted to my situation and I shall grub it out. It is the true Wragg, as I got it from the Wragg nursery

However, the best variety that has ever come under my observation in this country is one tree that stands in the yard of S. Chamberlain, 
in the city of Stanberry, Mo. For years it has yielded its full crops of large cherries, pleasing to the eye and good to the taste, milder yet than Early Richmond and more than twice as large, with smaller pit. It stood last winter without damage and bore a full crop this year.

\section{PRUNING, PLANTING, CULTIVATING, GATHERING AND MARKETING THE CHERRY.}

By W. H. Sxinner, Bethany, Mo.

I shall briefly outline the work on the cherry tree, from the time it reaches the premises of the orchardist until its matured fruit is placed in the hands of the consumer, and in the beginning will say that my experience in planting cherries has not been as satisfactory as in planting other kinds of trees, for my losses in planting my cherry orchard of 450 trees has been more than double what I have lost in planting over 2000 other orchard trees. But this I attribute largely to the condition of the trees when received. I believe that if I could get cherry trees that were dug, and immediately shipped, instead of being cellared over winter, there would be less failure to grow, as cherry trees of my own propagation dug and immediately planted have had no loss.

Cherries should be planted in this part of the country only in the spring, as our cold, dry winter winds have a tendency to extract the moisture from the tree, and the roots being short, with but little surface to absorb moisture, the tree is very liable to die back partly, if not entirely, during the winter. They should be planted in the spring, as early as the ground is fit to plow, and if possible before the buds begin to swell. They may be planted even after the buds begin to burst, but I have noticed that the carlier planted trees are more liable to live and make the better growth.

The cherry will grow on almost any kind of soil except a very wet one, but does best in a good sandy clay loam with gravelly subsoil. This seems to furnish the necessary drainage and sustenance to produce the hardiest tree and best fruit. Before planting the ground should be deeply and thoronghly plowed and pulverized. The roots of the trees where cut or broken in digging should be smoothly cut, and the hole in which the trees are planted should be large enough to admit the roots without bending; if it were possible to plow that deep, the hole should not be deeper than the ground is plowed, although I believe that cherries should be planted deeper than apples or pears. The roots should be puddled in soft mud before setting the tree in its place; the tree should be planted so deeply that the bud or graft is at least two inches below the surface when the hole is 
filled. The hole should be filled with fine mellow earth, carefully packed and tramped until the roots are well covered, and the earth should then be piled up a little to allow for settling, but the upper two or three inches should not be packed. Greater care is required in planting the cherry than any other variety of fruit I have ever tried.

I do but little pruning at time of planting; I prefer to plant small trees that noed no pruning. In March of the following year the trees should be gome over and pruned to shape the head: clip in the ends of the long shoots, keep the heads round, in the case of trees that grow like the Richmond, or conical with trees of more upright growth, and if the branches have not started thick enough to make a good head, cut back heary enough to make them thicker, the aim being to shape the head as near as possible to the shape of some well-grown tree of the variety. The following March, when the trees are two years planted, they should again be gone orer and pruned with the same end in view, that is, to make a well-shaper head, cutting out crosslimbs, heading back too rampant growing branches; and where a branch crooks or grows in a wrong direction it can usually be remedied, if taken in time, by cutting back to a bud that will start and carry its growth in the right direction. The third year the same treatment should be given, after which but little pruning will be needed, except to remove dead limbs, but these should not and, with proper treatment, will not be abundant for many years. In pruning the cherry, like all other trees, no fixed rule can be made that will apply to all, as no two trees are exactly alike; but the cherry being one of the inost perverse of all fruit-tree's, it is best for the pruner to have a well-grown, full-sized specimen of the variety he is pruning in his mind: this gives him the natural shape of the tree, and he should so train his young sprout as to cause it to assume its matural shape and make a rell-formed tree of its kind.

One of our modern horticulturists has said that the shape of the tree makes little difference with its bearing qualities and that each grower may form his own ideal shape of tree, and prune accordingly; but in pruning the cherry I would suggest that the pruner should have many ideals, as it is much more easy to make an ideal to fit a particular tree than it is to make all cherry trees grow to fit a particular ideal. No man should undertake to prune and shape the head of any young tree until he has studied the bud arrangement and growing characteristics of the family of trees to which it belongs, as the shaping of the top depends materially on the position of the upper bud left after the branch is clipped; and in shaping the heads of young trees particular attention should be giren that the cut is made 
so as to leave the upper bud in a position to start the new branch off in the right direction.

After planting comes cultivation, and this should begin immediately, and should be thorough, going over with a smoothing harrow or some other shallow working tool so as to loosen the ground which has become more or less packed by tramping while the planting was being done; again pulverizing two or three inches of the top soil, thus making a dust mulch to retain the moisture; this cultivation should continue during the summer to keep a dust mulch and keep down the weeds. The number of times it will be needed depends somewhat on the season and the perseverance of the weeds. The eultivation the second and following seasons should be the same as the first, except that the first cultivation should be with a tool going deeper than a smoothing harrow, such as a cultivator or spring-tooth harrow; about the fourth year the orchard should be sown to clover and left to grow during the fifth year, mowing it two or three times and leaving the clover on the ground to keep up the humus; and this will also have a tendency to check growth and bring the trees into bearing. About the last of May (or perhaps earlier) of the sixth year the clover should be turned under by a shallow plowing, after which the cultivation should be kept up with the harrow.

Included with the cultivation and pruning of the cherry orchard should also be considered its care, and whether you class it with the cultivation or with the care makes little difference; but the careful spraying of the cherry is one of the recpuisites that cannot and must not be overlooked to secure success and keep healthy trees. The leaf spot and powdery mildew are the great enemies of the cherry in this country, and without being in some way prevented are likely to wake up the orchardist some fine spring moming to a knowledge that his cherry trees are all dead. The great loss of cherry trees throughout the Northwest last winter, I am satisfied, was more from these diseases than from the extreme cold of February, 1899. By the middle of August, 1898, many of the bearing cherry trees had lost all their leaves from these diseases. The warm, damp weather of September started a new growth; many trees put out new leaves and some were in bloom, the sap was up; they were in full growth when the snow and hard freeze came, on October 17 and 18, and were killed then. If these trees had been thoroughly sprayed with the fifty-gallon formula Bordeaux mixture when the blossoms fell off, and again as soon as the fruit was gathered, the leaves would have held on until killed by frost, the trees would not have been growing in October, and would not have been injured by the cold. I did not lose a single sour cherry tree last winter. 
And now we come to the time of most interest to the cherry grower - the gathering and marketing - in which, especially the latter, I have had but little experience, as my orchard is just beginning to bear. But as I have given some thought and attention to this part of it, and have read everything on the subject I could find, so as to know what to do when I get a crop, I will give an outline of my gleanings from others.

The cherry should not be gathered until fully ripe and then only when it is dry, as, if it is gathered when wet or even damp from rain or dew, it will quickly spoil. In all cases the fruit should be carefully handled, and the stem should be left attached to the fruit, as the removal of the stem from the fruit will break the skin, aliow the juice to run out, and quickly injure the fruit. All defective berries should be thrown out, as they will injure the sale of the remaining fruit, and at this time it pays to pack only the best fruit and to put it up in a manner that will be attractive, as there is about as much in the packing of the fruit toward selling it as in the fruit itself, perhaps more. Cherries should be packed in small shallow boxes or baskets, which in no case should hold over one gallon, and handled so that they will not bruise or mash. As to the marketing of cherries away from home, all the questions of freight charges, commissions and commission men, and of markets, applicable to other fruits, apply to cherries. I have given this but little thought, for the reason that our home market has never been half supplied with cherries, and I believe that it will be many years before I shall have to go away from home to find a market for my cherries.

\section{WILL IT PAY TO PLANT CHERRIES?}

By G. W. Hopkins, Springfield, Mo.

Most every one in starting a new place will set out a few trees, but orchards exclusively of cherries are few and far between. There seems to be only two varieties that are worth planting in this locality - the Early Richmond and English Morello. The MIontmorency, it is said, does well, but few have fruited it.

Sweet cherries are not worth planting here, as they are very tender in the bud, and possibly one year in ten they may not be killed. If they are not killed in the winter or early spring, when they begin to ripen, the rains will crack the fruit and the birds destroy the crop. The curculio is very destructive to the cherry.

There is no question but cherries will pay well in sonth Missouri if there was any certainty of a crop. The Early Richmond comes in before strawberries are gone, and we have the whole southern country 
for a market. Three years ago I shipped Early Richmond to Memphis, some of which sold as high as $\$ 3.50$ per crate.

Of course there is big money in this, but I have not sold a cherry since. Now, there may be some sheltered places in south Missouri where the climatic changes are not so sudden, that cherries may be grown with profit. To those living in such favored places I would say, plant cherries. But after thirteen years of experience and observation in the vicinity of Springfield, I would say it would be rather hazardous to plant orchards of cherries for cummercial purposes, unless we could have assurance that the climate and seasons would change for the better.

\section{DISCUSSION,}

Major Holsinger, - I have several thousand cherries in bearing and have made more money from the cherry than from any other fruit. I favor the Montmorency and if I had to forego any kind it would not be the Wragg. I think the Wragg is better than the Early Richmond. For four kinds, I would take Early Richmond, Montmoreney, English Morello, and Wragg. These four make fruit through the season. The Wragg I have were propagated in Alabama, but is the same as the Iowa Wragg. My cherry trees planted in 1876 have paid well. We are burning them this winter for firewood. The first acre of these cherry trees I planted made $\$ 500$ per acre each year it was in bearing. If the others will last as long and pay as well I will be well pleased. Some of our cherry trees die in full leaf. I do n't understand the cause.

L. A. Goodman.-Of all the fruit I have grown at Westport the cherry has paid me best. Ten or twelve dollars per tree per year is not an uncommon yield. They should be planted in the proper soil and given the best cultivation for four years; after that time the tougher the grass sod the better. Not for sixteen years has the grass been broken. The roots are sensitive to being broken. When they are cut they begin to decay. The soil must be dry and not underlaid with hard-pan.

Question.- "What is the best stock for the cherry?" The discussion showed the Mahaleb to be the stock in common use. Mr. Callaway, of Illinois, said the common Morello was the best [stock]. Mr. Kiser sared his cherries by planting plenty of Russian mulberries for the birds; they much preferred the sweet little berries to the sour cherries. His loss from birds was nothing in his cherry orchard.

Question..- "Is clover a good crop for a cherry orchard four years old? And would you let it stand or cultivate alternate years?"

L. A. Goodman. - Clover is good. I would never cultivate after four years.

J. M. Invine. - At the last meeting of the Buchanan County Horticultural Society we discussed the cherry. It was said to be the most profitable fruit. Some are growing Dyehouse instead of Early Richmond. It is sometimes earlier and always as early as the Richmond. Montmorency, English Morello and Wragg are also grown.

J. E. MAY.-Is there any difference between the Large Montmorency and Montmorency Ordinaire?

Major Holsinger. - None whatever.

Mr. Baxter. - Mazzard stocks sometimes do better than those on Mahaleb stocks.

Mr. Butterfield. - The Mazzard sprouts.

Mr. BAXTER.-Morello is the best stock for the cherry. 


\section{CHERRIES FOR PROFIT.}

By J. P. Sinмock, Moberly, Mo.

Cherries are something the birds like very much; children also eat them with great relish. When a boy, I remember the old cherry orchard of Morellos, sprouting in every fence corner on my father's farm.

In those days we never thought of selling cherries. They were very plentiful, and the birds had great feasts among the branches; the neighbors also received a great many'.

The cherry is propagated by budding on the Mahaleb or Mazzard stucks, which are mostly imported from Europe, planted in the nursery rows, and budded in the following September. The buds take readily on Malıaleb when worked in September. We always use Mahaleb on account of its late growth in the fall, and it never sprouts from the roots.

There is no work in the nursery that I like better than growing the cherry. In these days we grow cherries for profit. If you want to plant a cherry orchard, select a nice rolling piece of land and plow (leep about the last of September or the first of October. They will do no good in wet soil. Then select your trees from the nearest reliable nurseryman. Buy nothing but good, No. 1, one- or two-yearold trees - one year is preferred. Buy those budded on Mahaleb stock and you will not be bothered with sprouts.

Select for early fruit, the Early Richmond; medium, Late Duke; and for late, the English Morello. Lay off the land about sixteen feet each way; begin planting early in November. In about three years you ('an begin picking the fruit. Cherry tree's have many advantages over apple and pear; rabbits or horers scarcely ever bother them, and the fruit comes at a time of the year when little other fruit is on the market.

An advantage with the cherry is, you can let them hang on the trees for a week or more after they are ripe; this gives you plenty of time to find a market. You can always find a good market at Omaha or Des Moines, if you cannot at some of your near-by towns, for a large quantity of them at a fair price.

The tree needs but little pruning. Start the head two and a half to three feet high. Keep all broken and dead limbs cut out. Grow potatoes or melons for two or three years and then you can sow clover and plow it under to stimulate the ground.

Pick your cherries with the stems on and put them in quart boxes or baskets, and you will be surprised at the way they sell and the amount 1000 trees will bring you. I have seen the fruit from a single 
tree bring ten dollars. My neighbor has eight or nine acres of cherry orchard, four years old, which brought him seventy-five dollars an acre last year. We need more cherries. Plant enough to ship in car lots, like we do peaches and apples. We ought to plant a variety of fruit.

The cherry will fruit as often and bring as much money and pay for itself before the apple begins to bear. When a man talks of planting an orchard, saying: "If it did not take so long for an apple orchard to bear I would plant it," I tell him to plant apples, and also ten acres of cherries to bring money to grow the apple orchard. In planting orchards, if we would pay more attention to cherries, pears and peaches, when the apple crop fails the fruit-grower would have more money. [Good!]

There are many varieties hardly worth planting. The Hearts and Bigarreau varieties will do but little good, as they are usually shortlived and bear but little, and are so good the birds get them all. The Dukes and Morellos are so sour the birds will not bother them if you will plant a few Russian mulberries along the fences. The English Morello bears like the Ben Davis apple. You can stand on the ground and pick most of the fruit and not bother with ladders, and it never dies in debt to you.

We have a neighbor planting a 200 -acre orchard. He is planting 5000 cherries and 5000 peaches. I think if more of our fruit-growers would plant cherries, peaches, and pears, as well as apples, they would have fruit to sell every year, and their bank account would hold up better from one apple crop to the next one.

\section{THE CHERRY.}

A paper by J. F. Cecil, Topeka, Kan., read before the Shawnee County Horticultural Society.

The growing of cherries in our section of the state is, so far as I am aware, limited to two or three varieties of the sour class. If any one has succeeded in getting a sweet cherry tree into profitable bearing in Shawnee county I have not heard of it. The first obstacle met with in the attempt is the bursting of the bark, which comes from the inadaptation of the tree to the soil and climate. I believe that successful crops have only been obtained from Early Richmond and English Morello, with many hopeful plantings of the Montmorency. The Early Richmond is the earliest, and a hardy, productive tree. Its fruit is usually more free of the curculio, and comes so early that it is seldom harmed by drought. Its fruit is small to medium in size, unless grown under very favorable circumstances. It is the most popular variety in the.West: as many trees of this variety are planted 
as of all others combined. English Morello makes a small, bushy tree, is an early and abundant bearer, not capable of withstanding as low temperature as the Richmond or Montmorency, but is less susceptible to bark-bursting during a long period of drought. It is very subject to leaf-blight, and easily succumbs to the ill effects of excessive moisture. Fruit medium to large in size, roundish in form, in color almost black when fully ripe, flesh very dark and sour; regarded by some as a good canner. Begin to ripen from the middle to the last of June.

Montmorency is a very large, light-red, long-stemmed cherry, flattened on the ends, flesh more solid than in the Richmond, and of about the same flavor. The tree is a strong, erect and symmetrical grower, and, all points considered, it is with me the hardiest of all. I have found young trees unproductive; but Mr. Bailey, of Cornell, claims it to be a bearer of great crops of fruit, even outdoing the English Morello when in full bearing, which is a year or two later than that variety. He refers to a $\mathrm{Mr}$. Scoon, who considered a crop of eight to ten tons a good one from his 800 trees, and, selling at five cents a pound, brings $\$ 1$ per tree or $\$ 130$ per acre from trees set eight years. Mr. Bailey thinks this a very conservative estimate. Another case is cited: Mr. Kean, of Seneca, has 200 Montmorency six years set; has had three crops, one of 1400 , one of 3000 and one of 3100 pounds, and, at five cents, means $\$ 375$ for the three crops. His trees are set $10 \times 12$ feet, which allows 360 trees to the acre: this means that $\$ 375$ was taken from a little more than a half-acre in three years. Another experience: A Mr. Perkins, with thirty-five trees, eight and twelve years old, yields from $\$ 100$ to $\$ 175$ a year. All of this is encouraging to me, for, up to this time, my experience led me to conclude that unproductiveness was its only weak point.

Ostheim is of about the character in tree and fruit as the English Morello, probably less acid, and may become more popular when known, but is not very extensively planted at present. Louis Philippe is considered valuable by some growers in the East and has some good points to recommend it for trial by Western growers. A few trees of the Late Duke in my neighborhood have given their owners pleasure and profit. My own profits in cherry growing have come from the English Morello. I had 150 yearling trees set in the spring of $1888,10 \times 15$ feet, among raspberry plants set two years before. In 1891 we picked the first fruit for market, which was thirty-one cases, and sold for $\$ 46.50$. Our best crops were had in 1895,1896 , and 1897. The crop of 1895 was 128 cases, and sold for $\$ 228.43$. These trees occupied 22,500 square feet-a few feet over one-half an acre. ¿ ${ }^{\top}$ ) to 1891 we were receiving paying crops of raspberries. 
In selecting a site for an orchard, care should be had to get a piece of deep loamy soil, free from stagnant moisture; it should be well drained, either naturally or otherwise. No fruit plants, unless it be the grape or peach, will so quickly or effectually protest againt the presence of excessive moisture as the cherry. Deep plowing and thorough after-preparation are very essential. Lay the rows twenty feet apart and set the trees twenty feet apart in the row. My first experience was with tree's set $10 \times 1$ o feet, which I found to be entirely too close; a later planting was made in setting $161 \times 20$ feet, and this also is too close for Early Richmond and Montmorency, but probably sufficient for English Morello. Two-year-old trees are usually chosen. But I am of the opinion that a closer and better acquaintance with young trees would lead to a general planting of onc-year-olds. It is true that a little care and training would be transferred from the nurseryman to the orchardist, but this will be compensated for by an earlier establishment and fewer losses in transplanting.

When planting one-year-old trees they should be trimmed to a single stem, being ('areful to rub off all superfluous shoots as they appear, locating the head as desired, and cherry trees should be lowheaded. The pruning in after-years should consist of cutting ont such branches as interlock, and the successful orchardist will sooner or later recognize the fact that the cherry tree will resent any unnecessary mutilation by a decline in vigor and early decay. Cultivation should begin early in the spring, after planting. Such crops as strawberries and raspberries may be cultivated in the orchard for three or four years. But where this is practiced the loss to the soil should be repaired by applying suitable fertilizers. These should not be too rich in nitrogen but have a large percentage of potash and phosphoric acid. A much better crop for the orchard is soy-beans or cow-peas; in every case it is necessary to keep plenty of fiber in the soil. After the third or fourth year no other crop should be allowed in the orchard, and shallow and thorough cultivation should be commenced early in the season and continued until the fruit is harvested, after which a cover crop should be sowed. I am thoroughly convinced that orchard cultivation should include a cover crop. Indeed, I find that on slope lands it is impossible to cultivate orchards without the aid of cover crops to prevent great losses by washing.

All will concede that most if not all of our fruit plants should receive their cultivation in early spring, and that late tillage in most cases means a late growth that will endanger the succeeding crop, if not the life of the plant. Thus we find it convenient and necessary to sow a cover crop. A variety of plants may be used for such crop, such as cow-peas, oats, sorghum. millet, buckwheat and, if the soil is inclined 
to be too wet in seasons of excessive rainfall, rye or winter wheat may be used to take up some of the excess by growth in the spring, care being taken to plow under in time to check any undue loss of moisture by allowing to grow too late. The curculio is the insect that has destroyed some crops of this fruit and is abont the only pest it has. In some seasons it hecomes a scourge, and jarring onto sheets and destroying it is ahout the only remedy. Leaf-blight with me has not been serious except in very wet seasons and $I$ am very sure that it can be held in check or entirely prevented by thorough spraying with Bordeaux mixture. I have been able to hold the leaves on nursery trees until late in the season by its use when unsprayed trees in the immediate vicinity were entirely denuded, but the applications were made at the time the fruit was ripening and a little earlier; this would prevent its use in the orchard. I have thought that early spraying for several snccessive seasons would tone up the trees and carry them through the season unharmed.

Two or three pickings are sufficient to go over the Early Richmond and Montmorency, but the English Norello should have more frequent attention to get the fruit into market at its best. I have marlieted all of my fruit in twenty-four-quart cases and paid the pickers from one to one and one-fourth cents per quart, the condition of the 'rop regulating the price. Some growers use ten- and twenty-pound baskets for marketing, which may do for a near-by market.

\section{- THE CHERRY.}

A paper by J. W. Johnsov, read before the Allen County Horticultural Society February 9, 1900.

The cherry is no longer considered simply as a luxury, but as a staple fruit, and few of our orchard products can be served in more varied or tempting forms. But few seem to give it more than a small place in their orchard, many giving it far too little thought. Mr. Wellhouse, in talking of "Apples for Profit," said he plants but few rarieties, and these well known as adapted to climate, seasons, and the market upon which he depends for profits. These are essential in the cherry orchard for profit and also for home consumption, and should be incorporated in our plans.

Our suggestions to one contemplating the setting of a cherry orchard for the money profits are to keep in mind these points: Soils adapted to the cherry: care in setting and culture; varieties adapted to your locality; the succession you desire: and the market you can reasonably hope to find.

As to the soil, Downing says that "a sandy or gravelly soil is the 
cherry's favorite home"; therefore good drainage should be one especial point needing attention where a compact subsoil is known to exist near the surface, as the cherry is a shallow-rooted tree, and too much moisture about the fibrous roots when the trees are small will greatly lessen the prospects of a vigorous growth. A. N. Swigart, of Iola, suggests the digging of one or more trenches to lead the surplus moisture away from the trees while young, as all trees in this climate that are budded on to the French Mahaleb roots are hard to get started, but if carefully set, cultivated, mulched, watered and protected from surplus water during the first year are usually safe and profitable, and are always non-sprouters - the latter characteristic being a very important one.

Of varieties, we shall mention only those that have been found worthy and proven their merits in the experiences of our members and neighbors. There are three primary varieties that have a part in subject, viz., Dukes, Morellos, and sweet or Bigarreans. Of these the first two are sour, and they hare many crosses and do well in our county. Of our succession, the first would be the Dyehouse, which ripens in June; the Early Richmond, a very popular and rich variety, a week later; then Olivet, one of the Morello family, but not so tart as its parents; next Montmorency, of which there seems to be two kinds, early and late. Of the early, Mr. Grosbeck planted four trees in Iola; they were well cared for while young, and now annually produce five dollars' worth of cherries per tree, and one year doubled that yield, we are informed. The fruit is large, rich, and ripens in June. English Morello should not be omitted, as it seldom fails to bear a full crop here; but care should be exercised to select your trees from a good kind of the many Morellos. They are a good cherry for shipping, ripening in August, but will sprout upon the slightest provocation. We have not found the sweet varieties profitable here, and do not advise their culture for profit, but for variety, a few in especially favored localities. Of these Governor Wood has proven the favorite in our locality. It is a cross between the Morello and Bigarreau, in which the former shows in the form of the tree and leaf, but the fruit is a true Bigarreau, except it is of a lighter color. Some scientists claim that our climatic conditions are undergoing a change, and that our fruits are affected less by the drying winds, and that our moisture supply is more sure, which, if true, may give the sweet cherry a hope for success; but of that we cannot now advise.

As to pruning, the cherry should have a symmetrical top started by the judicious grower, and then he should stand back to watch its development and guard it from the youngsters. We are told that in Europe the cherry is planted along the roadside, and cared for and 
protected by law, and that the fruit is used by the public. We think the latter part of this arrangement is fully understood by the young American. His by-laws may not be very explicit, but he rery promptly incorporates this fruit as a part of his constitution.

Regarding the market, the outlook for a large and brisk demand, unsupplied by home growers, is most promising just now for enterprising and wide-awake producers to secure.

\section{THE CHERRY.}

By B. F. Sмттп, Lawrence, Kan.

The cherry commonly known in this country originated in Asia. One of the old historians says it was first brought to Italy by Lucullus after his victory over Mithriclates, seventy-four years before Christ. Pliny repeats a tradition that it was brought to Rome from Syria. Cherries were extensively grown by the Romans, and it is supposed they introduced them into Britain in the third century. While its history is somewhat enveloped in the fog and darkness of past ages, still we are led to believe that the genesis of the cherry was in the garden of Eden, where doubtless the apple, pear, peach and quince had their origin.

Some authors make four classes, but really there are only two classes, sour and sweet cherries. The Hearts and Bigarreaus are sweet. Trees of the sweet sorts are lofty and rapid growers, with large leaves. The Dukes and Morellos are slow growers, forming low, spreading trees; dark green narrow leaves, and acid or subacid fruit. Sweet cherries are adapted to dessert, and are cooling and refreshing when fresh from the trees. The Dukes and Morellos are too sour for dessert, yet they are most valuable in the North for canning and commercial use.

The cherry does best on moderately dry soil, yet it will thrive on almost any soil where corn and the cereals grow. Some varieties succeed as far north as Norway, sixty-three degrees north latitude. In some parts of Germany the public roads are lined with cherry trees for many miles.

A few kinds are true to the parent and can be raised from the seed, but the most raluable varieties usually have no meat in the seed. Good seedlings averaging eighteen inches high may be transplanted from the seed-bed when a year old, and if well cultivated may be budded the same season. Where the buds fail, grafting may be done the following spring.

The cherry orchard should be well cultivated for at least four years, 
or until the trees have borne one or two crops of fruit, after which the cherry orchard may be seeded to clover or blue-grass.

In some localities the sweet or Heart cherries are failures as a commercial product. Yet a few of these may be planted for ornamental purposes. Then, should there come a favorable season, maturing the fruit, they will be found pleasing and profitable." The best of the sweet sorts are Black Tartarian, Napoleon, Windsor, Governor ITood, and Black Eagle.

For all commercial traffic and home consumption acid cherries are in great demand, and they are being more largely planted for profit than sweet cherries. In the selection of a list of sour cherries for market, the time of ripening is an important feature. Early sorts come in about the second week of strawberry picking; hence they do not sell as well as the later kinds. Therefore the writer would not favor the planting of the Early Richmond for market purposes.

The best selling cherries are Ostheim, Montmorency, English Morello and Lonis Philippe. Fruit of the Montmorency is light red, flesh nearly colorless. It is largely grown in some localities for canning. The fruit of Louis Philippe is dark red, flesh same color and fine quality. English Morello ripens two weeks later than Montmorency; fruit is a dark red, nearly black when ripe; flesh dark red and very sour; tree is a slow grower but begins to bear when two or three years old. It is a favorite with cauning factories. The Ostheim ripens soon after Early Richmond. It is popular, but rather too early for those who demand a late cherry.

Trees should be cut back the first two or three years to make the hear spread. At the same time the head is kept low, which serves to shade the trunk from the sun.

It is the custom in our locality to set trees about $12 \times 12$ feet, but the writer would plant a cherry orchard $16 \times 16$ feet apart.

Cherries are but little affected by insects, however, occasionally the curculio is troublesome, still not to the extent as that of plums. While cherries are not as profitable a fruit for commercial traffic as apples, pears, and peaches, yet the trees are ornamental, the fruit is handsome, pleasing to the eye and palates of children and birds.

Then, with all, a valuable addition may be made to the winter store of camned fruits for farmer and fruit-grower. Therefore a small cherry orchard will add five times its cost to the value of any farm home in the country. 


\section{THE CHERRY.}

By AlBert Dickens, Manhattan, Kan.

Cherries are as nearly sure as any crop we grow in Kansas, yet. while we find the raising of corn. wheat and potatoes profitable, cherries are neglected. The cherry is a rival of the late strawberry and early raspherry, but it has enough merits of its own to entitle it to a place in erery fruit garden. There is little danger of raising too many cherries until they are so plentiful that prices on them are quoted by the peck or bushel instead of by the quart; in fact, the vast majority of home-owners raise fruit for the table rather than for market.

We have picked cherries, perfect in every particular, that were bome by trees grown in all sorts of soils, from the high uplands in Scott comnty, through all the grades of the sandy soils of the Arkimsas valley, to the limestone soils of eastern Kansas.

One good erop of cherries will pay for the tree, the trouble, and the rent of the land, so, if the trees are short-lived, we should plant oftener. A few good trees are enough for the family use, and if one plants for the market he must calculate as to the distance to market. the supply of pickers, and his ability to handle the crop. For market, the stem must be picked with the fruit; for home use they are often shaken from the tres and caught upon a sheet. If not picked as soon as ripe they are liable to rot badly. Good cherries are well worth all they cost, they have a place in the fruit list which no other fruit can fill.

Set the best trees obtainable. Our own nurseries quote fine trees at a quarter of a dollar; less money for larger lots. Set as carefully as you would an evergreen, a strawberry plant, or a [helpful] hen. Make the hole large enough to allow the roots a natural position; cut back the bruised roots with a smooth cut on the lower side, cut the top back in proportion to the roots: put good soil around the roots; fill in firmly to prevent drying. If the weather department shortens the water-supply, draw a couple of inches of earth up to form a pool, give the tree a bucket of water, and do not forget to loosen the soil and draw the dry earth over for a mulch. If you are master of your time, it is better to put the water on in the evening and draw the dry earth over in the early morning, before the sun can bake the wet soil and so deprive the tree of its supply of air. Keep the trees well cultivated, and look at them with your best eye occasionally and criticize their forms. Think of the tree as it should appear in a few years, and pinch off a spront when it is liable to make a branch that will in a short time rub its neighbor.

The sour cherries are most widely planted and most successful. 
The Early Richmond and the Montmorency of the light reds and the English Morello of the dark reds are as good as the best. May Duke belongs with the sweet cherries botanically, and is more generally successful than any other of that class. It is nearly as sour as the real sour cherries.

\section{INDIVIDUAL EXPERIENCES.}

E. T. Daniels, Kiowa, Barber county.-I have twenty cherry trees in bearing, planted from eight to fourteen years; the Early Richmond and English Morello do best for me. My soil is a dark silt upland, underlaid with red rock at three feet, and a poor location. I plant twelve feet apart. Have grown, budded and grafted my own trees. If planting over, I would set the two rarieties named and another which I do not know the name of. My neighbors grow very few cherries. The fruit was troubled with curculio only one year, for which we did nothing. I expect to put out quite an orchard and believe there is money in them. I do not irrigate my trees.

W. G. Osbor'n, Medicine Lodge, Barber county. - I have about fifty cherry trees in bearing, planted from five to fifteen years. They are May and Morello. My soil is level bottom land. I plant twelve feet apart. Gather when ripe; use them at home. Have never grown, budded or grafted my own trees. Some of my neighbors are growing cherries. I consider them a good paying crop in this locality. They are troubled with birds only; I shoot them occasionally. Do not irrigate my trees.

C. A. Blackmore, Sharon, Barber county.-Early Richmond bears early, but the birds get a good share of the crops. I plant Russian mulberries near by to help keep the birds from the cherries. English Morello is a splendid cherry and a prolific bearer. Montmorency Ordinaire is a very large, fine cherry. Dyehouse is yet too young to bear with me. Abbesse Sweet Duke, a very rank grower, is now four years old and has not fruited yet. The common Morello falls badly when stung by insects. Early Richmond and common Morello first bloom April 22, are in full bloom April 27, and have fallen by May 2. Montmorency Ordinaire and English Morello first blooms appear April 26, are in full bloom April 29, and have fallen by May 6.

Geore Ettridge, Roberts, Barton county.-I have Early Richmond and English Morello in bearing - forty trees set two jears ago this spring, twenty Early Richmonds and twenty Large Montmorency. Cherries do well here; there are no insects to bother them. I do n't think the English Morello is very good for this upland; it is too late ripening. I have about 100 Russian mulberries, and the birds feed on them, and do n't seem to bother the cherries. I have nover used any fertilizer until this winter; I am putting stable litter around my trees (not near the trees, over the ground). I always tie hay around the trees early in the fall to keep rabbits from gnawing them. I set out two-year-old trees in the spring; would not take trees of any kind as a gift and set them in the fall. Where I set trees I plow the ground early in the fall, deep as a team can pull the plow; I dig holes sixteen inches square, set the trees a little deeper than they stood in the nursery, trim all roots to about six inches of the body, and cut the top back well. When they are set they look like little sticks stuck in the 
ground, ten feet apart, with a few short limbs. When setting I fill the hole with surface soil, put the tree in the hole, put three or four inches of soil in, then half a bucket of water. After a dozen or so are thus set I go back and fill the hole up, making the soil firm with the foot. I nerer plow much with a stirring plow, but use the two-horse cultivator, and cultivate whenever it is necessary to keep tho weeds down; that is generally three or four times. Never let live stock among my trees; do not trim cherry trees much. One of my neighbors who lives on the creek has the largest Early Richmond tree I ever saw. He told me he picked three bushels of cherries off that tree when cherries were selling at three quarts for twenty-five cents, and that tree produced about eight dollars' worth of fruit; and yet some say it does not pay to set out trees in this part of the country. Well, it do n't the way ninety per cent. set them out. In the first place, we people out here are bought and sold and hoodooed with tree peddlers. They generally set out their trees in the fall because the peddler says to. If there happens to be life in any of them the rabbits gnaw them. If some leaf out in the spring, they look the patch over, and say "it do n't pay." The weeds grow up six or seven feet high, and they are disgusted with fruit-trees, and swear they will never buy another one. An Ohio nursery delivered $\$ 3000$ worth at Hoisington a year ago last fall. I do n't think one tree is alive. I would not have taken the lot as a gift.

Geo. T. Elliott, Great Bend, Barton county. - I have forty cherry trees in bearing; been planted twelve years; the varieties are Early Richmond, Montmorency, and English Morello. Sweet cherries do not do well here. The English Morello and Montmorency are the best bearers. My soil is sandy, sloping to the east. Plant sixteen feet apart; market in baskets holding from twelve to sixteen quarts, in Great Bend, receiving ten to fifteen cents per quart for them. If planting over, I would put out the three varieties I am now growing; cherries do not do very well here; I think the varieties named are best adapted to central Kansas; they bear every year; would not plant extensively. My trees are troubled with no insects, but gophers bother some, which I trap. I do not irrigate my cherries. It is no trouble to raise cherry trees here in Barton or Stafford county.

J. R. Dunkin, Sharon, Barber county.--This seems to be the home of the cherry; trees grow vigorous, and are as a rule hardy, and bear abundantly unless caught by late frosts. Varieties mostly grown here are Dyehouse, Early Rich. mond, May Duke, English Morello, Niontmorency, Governor Wood, and the old common cherry, known to every boy large enough to climb a cherry tree. There should be more cherries planted. They require little attention, can be set in any old place, and make their own living and produce a crop. The cherry is a good seller here and finds a ready home market.

A. S. Huff, Enon, Barber county,-The cherry is one of the most useful crops in this county, and one that commands a good price and ready sale; a fruit that nearly everybody appreciates for cinnning; and, like the plum, an everyyear crop with me. I would recommend the planting of more cherry trees. There are but few trees in this part of the state, in fact, not enough to supply the home demand, and we cannot get too many. What few trees there are seem a wonderful success in this part of Kansas. 
J. B. Saxe, Fort Scott, Bourbon county.-I have thirty cherry trees in bearing; been planted five or six years; they are Black Morello and Early Richmond. Morello is the best bearer. My soil is clay, nearly level. I planted my trees about twenty feet apart. Have grown, budded and grafted my own trees. If planting over, I would set out a half dozen Morello. My neighbors grow a few cherries; I do not consider them a good paying crop in this locality.

S. F. C. Garrison, El Dorado, Butler county.-I have forty cherry trees in bearing; been planted from ten to fifteen years. I find Early Richmond to be the best bearer. My soil is upland, sloping to the east. Plant the trees $12 \times 15$ feet. If planting over, I would put out Early Richmond. I do not consider them profitable in this locality. They are troubled with curculio, for which we sometimes spray. I do not irrigate my trees.

Dick May, Elk, Chase county. - I have fifteen cherry trees in bearing, planted ten years; they are Morello, which I find to be a good bearer. My soil is second bottom, sloping to the east; plant my trees fifteen feet apart. Use all the fruit at home. Have never grown, budded, or grafted my own trees. If planting over I would set out Early Richmond. My neighbors are growing cherries on a small scale; I consider them a good paying crop in this locality; they are troubled with no insects. I do not irrigate.

A. D. Armold, Longford, Clay county.- I have six cherry trees in bearing; been planted ten years; they are Early Richmond, Dye House, and Montmorency. I consider cherries one of the surest and best paying crops in this locality. My soil is a sandy loam, sloping west. I plant twenty feet apart. Have never budded, grown, or grafted my own trees. If planting again I would put out Early Richmond, Montmorency, and Dyehouse. Of these I planted fifty a year ago; they have done extra well. Neighbors grow a few cherries. My cherries are not troubled with any insects. Do not irrigate them.

Joln Reed, Longford, Clay county.-I have only a few cherry trees in bearing. The Early Richmond seems to be the best cherry for this locality. I would advise all farmers in this vicinity to plant cherries of that variety.

J. H. Bilsing, Udall, Cowley county.-I have sixty cherry trees in bearing, which have been planted eighteen years: they are English Morello, Black Morello, Early Richmond, and Royal Duke. The best bearers are Early Richmond and English Morello. My soil is loam intermixed with sand; it is level. Plant my trees sixteen feet apart. Have grown, budded and grafted my own trees. If planting over, I would set out Early Richmond, Royal Duke, Montmorency, and English Morello. They should be well cultivated for several years after planting. My neighbors grow a few cherries. I consider them a moderatelypaying crop in this locality. They are troubled with curculio, for which we do nothing. Do not irrigate my cherry trees.

J. H. Sayles, Norcatur, Decatur county.-I have 600 cherry trees in bearing, planted in 1890, 1893, and 1894; they are Early Richmond, Montmorency, English Morello, Ostheim, Empress, Eugene, and two unknown kinds. Of these the best bearers are English Morello, Montmorency, Early Richmond, Ostheim, and Valdimir. My soil is rolling prairie, 170 feet to water, sloping to the north- 
east: planted my trees $16 \times 20$ feet; pay one cent per quart for gathering them ; my family do most of the work; market in crates holding twenty-four boxes: sell at Goodland, Colby, Norton, Oberlin, and the orchard, receiving \$1.85; with stems on, $\$ 2.10$ stems off, and $\$ 3$ per bushel at the orchard. Have grown, budded and grafted all my own trees. If planting over, I would set out Valdimir, English Morello, Montmorency, Farly Richmond, Olivet, Ostheim, Empress, and also a large sweet, luscious late variety [Late Duke], name unknown. My neighbors grow a few cherries, but buy most of them from me. I consider the cherry business "a gold mine" in this locality. They are troubled with no insects. Let my chickens run in the cherry orchard. Never irrigate nor mulch my trees, but cultivate often. We plant yearling trees, by plowing a ditch as deep as can be; then plant trees deep and mulch at once; rains fill ditch: cultivate often; trees hear second year. Joung orchard five years old averages a crate per tree, worth $\$ 2$; seven-year-old orchard, one bushel each. Trees planted in 1890 are failing, losing vigor. We planted 1000 trees last spring: all are looking fine. Can't supply the demand. Will put out 1000 trees in 1901. [Mr. Sayles sent to this oflice, on July 18, 1900, some splenctid specimens of Late Duke, also fine Morellos, from three- and four-year-old trees.-SEC.]

P. Wayner, Dresden, Decatur county.-Have twenty cherry trees in bearing - fifteen sour and five sweet. Cannot tell which are the best bearers, as they are just coming into bearing. My soil is a clay loam, sloping to the east: plant sixteen feet apart. Neighbors are growing some cherries. I consider them a good paying crop in this locality: they are troubled with no insect. Do not irrigate my trees.

Is:ar. Clark, Oberlin, Decatur county.-- I have serenty cherry trees, planted eleven years, fifty of which are sour and ten sweet varieties; all do well. My soil is sand and clay, with a northern slope. Plant fifteen feet apart: gather the fruit in July; market in boxes, at Oberlin, receiving from eight to ten cents per quart. Have never grown, budded or grafted my own trees. My neighbors grow cherries: I consider them a good paying crop. They are troubled with grasshoppers, but we do nothing for them. Do not irrigate my trees.

I. II. Taylor, Richmond, Franklin county.- I have six cherry trees in bearing, which hare been planted twelre sears: they are the Early Richmond. My suil is a sandy loam, sloping to the east. Use all the fruit at home. Hare never srown, budded or grafted my own trees. If planting over, I would put out Early Richmond. My neighbors grow only enough for home use. I would not consider them a good paying crop in this locality. They are troubled with worms, for which we do nothing.

John Bailey, Harper, Harper county.--I have about twenty cherry trees in bearing, planted fro" 1 four to ten years. Those bearing best are Early Richmond and Large Morello. My soil is black, fandy loam, level. I plant twenty feet apart. Sell the fruit in Harper, receiving from five to seven cents per quart. Have nerer grown, budded or grafted my own trees. If doing it all over again, I would plant Early Richmond and Morello, and any other varieties that have proven a success in this county. My neighbors grow cherries. I consider them a good paying crop. Have had very little trouble with insects. Do not irrigate. 
D. D. White, Enon, Harper county. - I have twelve cherry trees in bearing, planted ten years. My soil is a sandy loam, about level. Planted my trees twelve feet apart; gather the fruit when ripe; use it all at home. Have never grown, budded or grafted my own trees. If planting over, I would put out Early Richmond, or May and Black Morello. My neighbors are growing cherries. I consider them a fairly paying crop in this locality. They are troubled with no insects. Do not irrigate my cherries.

F. W. Dixon, Holton, Jackson county, - Of all our fruits the cherry is the easiest grown and most profitable; trees never require any attention after being cared for four or five years. It is true we have failures, but generally get a good crop of salable fruit. Dyehouse is a little earlier than Richmond; tree not as good grower and not as hardy. Early Richmond is a standard early cherry, and so far has proven the best paying. Montmorency is an annual bearer, about ten days later than Early Richmond, but not so prolific. Fruit very large, good flavored, and of fine appearance; tree very hardy, a fine grower, and quite ornamental. Wragg has proven to be inferior in size to English Morello. English Morello is the standard late cherry. Trees were badly damaged by the cold of February, 1899, and are generally short-lived because of their extreme productiveness; we have picked two bushels of cherries from trees so small that fruit could all be picked while standing on the ground. Sweet cherries have not proven profitable. Governor Wood withstood the cold of 1899 all right, but the winds usually manage to get all the fruit before it ripens. Cherry trees generally were badly damaged by cold of 1899 , all the older trees being killed. The extreme limit of life of a cherry tree in this climate is about fifteen years. The cherry requires a welldrained soil, and will succeed on no other; a porous clay subsoil is preferable.

H. S. Cutter, South Cedar, Jackson county.-I learned from planting the following varieties of cherries, Farly Richmond, Late Richmond, Dyehouse, Early Morello, Ostheim, that for me the Early Richmond is the cherry for this part of Kansas.

F. L. Osborne, Soldier, Jackson county.-I have eighteen cherry trees, planted fifteen years. They are Montmorency, Ostheim, and Richmond: of these the best bearer is the Montmorency, although the other two varieties are good bearers. My soil is a black level loam. I plant sixteen feet apart. Gather them when ripe and sell in the orchard, receiving eight cents per quart. Have never grown, budded or grafted my own trees. If planting over again, I know of no better varieties than the above-named ones. Would set them in ground free from sod, eighteen feet apart, cultivate well, not allowing the weeds to grow.

E. M. Gray, Perry, Jefferson county.-In 1885 I planted a small cherry orchard: varieties were Early Richmond, Montmorency. I planted them on a southern incline, sandy, black soil; have had a good crop every year since coming into bearing, except last year the crop rotted just before ripening; the cause of the rot, I think, was too much wet weather and no cultivation. In $1890 \mathrm{I}$ planted about 200 cherry trees on three different slopes and soils-No. 1 on southern slope, dry, sandy soil; No. 2 on northern, black, wet soil; No. 3 on western slope, a red, dry soil. The varieties were Early Richmond, Large Montmorency, Wragg, Dyehouse, English Morello, May Duke, Ostheim, Sula Hardy. My experience as to soils is that cherries want dry feet-light, dry, loose soils. I had bad success on wet land, and I recommend clean cultivation up to tha middle 
of August. The only varieties I am planting now are the Early Richmond and Montmorency for commercial purposes. I sell them in berry crates and halfbushel baskets at fifty cents per basket, one dollar per crate. I pay two cents per box for picking.

E. P. Diehl, Olathe, Johnson county. - I have sixty cherry trees in bearing, been planted twenty-five years. My best bearers are Early Richmond, English Morello, and May Duke. My soil is a black loam, sloping north and south [?]; I plant twenty feet apart, and gather the fruit when nearly ripe; marliet in onethird bushel crates at Olathe, receiving from five to ten cents per quart. Have grown, budded and grafted my own trees. If I had it to do all over again, I would plant Early Richmond, English Morello, May Duke, Montmorency, and Golden Spanish. Some of my neighbors grow cherries; I consider them a good paying crop. The curculio trouble my cherries. I spray for them.

J. C. Beckley, Spring Hill, Johnson county,-Have twelve chorry trees in bearing; planted twelve years. The rarieties are Early Richmond, Montmorency, Wragg, and English Morello. These varieties bear about equally. I have twenty trees which are not yet in bearing. My soil is black mulatto, sloping slightly to the west. Plant two-year-old trees in the spring, sixteen feet apart; gather in baskets holding four quarts; market in Spring Hill in baskets, receiving from five to ten cents per quart. Hare never grown, budded or grafted my own trees. If planting again, I would put out the above-named varieties in an orchard, sixteen feet apart, and give good cultivation for four or five years: then keep the surface clean under the trees, to prevent insects from harboring there. My neighbors do not grow many cherries. I consider them a good paying crop in this locality. The fruit is troubled with curculio, for which we have sprayed some.

C. H. Long'streth, Lakin, Kearny county. - I have :300 cherry trees in bearing, planted ten years. The varisties are Early Richmond, English and Common Morello. Of these the best bearers are Early Richmond; the others are nearly as good. My soil is a deep sandy loam, very nearly level. I gather by hand, picking with stem; market in crates containing twenty-four quart boxes. Sell at Denver principally, receiving from two to three dollars per crate. Have never grown, budded or grafted my own trees. If planting over, I would put out the varieties $I$ am now growing, and a few other kinds for experiment. My neighbors grow a few cherries; I consider them a fairly good paying crop here. The fruit is not troubled with any insects. I irrigate my trees only when severe drought occurs at time of planting. Cherry trees do better in clay soil, with but little water, to get best results.

Geo. Iildreth, Altamont, Labette county. - I have twenty-five cherry trees in bearing, planted five and ten years ago. Early Richmond is the best bearer. My soil is dark limestone, sloping towards the west. I plant twelve to twenty feet apart; gather when ripe, this year the 2Sth of May. If I had it to do over, I would plant Early Richmond, English and Common Morello. Neighbors grow some cherries. The curculio troubles them.

N. Sanford, Oswego, Labette county. - I have twenty cherry trees in bearing, planted from two to twenty years; am growing Early Richmond only. I plant in rows thirty feet apart. I use ladders in gathering them, and market in boxes. I sell in Dallas and other points in Texas; usually receive from $\$ 1.25$ to $\$ 1.50$ per 
case. Have never grown, budded or grafted my own trees. My neighbors grow cherries. I consider them a good paying crop in this vicinity. They are troubled with the curculio; we spray with London purple and lime.

D. E. Bradstreet, Dighton, Lane county. - I have ten cherry trees in bearing, varying in age; they are Early Richmond. My soil is a dark loam, about level. Have never grown, budded or grafted my own trees. If planting over, I would set out Early Richmond and English Morello: would plant them between my apple trees. My neighbors grow a few cherries. I consider them a fairly paying crop in this locality. No insects trouble them. I do not irrigate my trees.

W. M. Fleharty, La Cygne, Linn county, - I have forty cherry trees in bearing, planted four years; they are Early Richmond. My soil is black allurial, sloping to the east. Plant trees twelve by twenty feet. If planting over, I would put out nothing but Early Richmond. I consider them a good paying crop when taken care of. The fruit is troubled with curculio, which I gather and destroy. Do not irrigate my trees.

Dr. J. Stayman, Leavenworth county.-After trying nearly all the popular leading varieties of cherries, the following are the best and most profitable for Kansas: Dyehouse, Early Richmond, English Morello, Wragg, Ostheim, Olivet, Montmorency, Black Tartarian (in favorable locations). For trial: Baldwin, of Kansas; Windsor, of Canada; Mercer, of Pennsylvania.

D. C. Overly, Hartford, Lyon county. - I have 300 cherry trees in bearing, planted nine years; they are Early Richmond. My soil is black loam, sloping to the south. I planted my trees fifteen feet each way, but would plant $15 \times 18$ if planting again. Gather them in Lesley (wine measure) boxes, receiving from ten to twelve cents per quart; in 1899 I received ten cents per quart. Market them in twenty-four-box crates. Sell at the orchard and in Emporia. In 1898 I gathered 2000 boxes and sold them at 6 ? cents. Have never grown, budded or grafted my own cherry trees. If planting over, I would set out Early Richmond, as it is a sure shot every year, but not a full crop every year; on short crops I get about as much money as on full crops; the longer you are in the business the better prices you get. Do n't plant cherries on level land. My neighbors do not grow cherries. I consider them a good paying crop in this locality. I spray, and have no trouble with insects. I do not irrigate my trees.

J. T. Barnes, Beloit, Mitchell county.-I have seventy-five cherry trees in bearing, planted from two to ten years. They are Early Richmond, Dyehouse, Montmorency, Ostheim, English Morello, Empress, Wragg, and Sweet May Duke; of these the best bearers are Early Richmond, Dyehouse, Early Morello, and Montmorency. My soil is sandy loam, river bottom, sloping towards the southeast. I plant in rows fifteen feet apart, trees twelve feet apart in the row, which is too close. I gather them by hand, with hired help, and market in bulk; sell at home or Beloit for five cents per quart. Have never grown, budded or grafted my own trees. If I had it all to do over again, I would plant English Morello, Early Richmond, and both kinds of Montmorencys, in rows twenty feet apart, with the English Morello and others sixteen feet apart in the rows. My neighbors grow cherries, and we consider them a good paying crop. The fruit is rarely troubled in this section. Do not irrigate my trees, I depend on frequent ultivation. 
J. C. Ross, Havana, Montgomery county, - I have 200 cherry trees, planted two, four, and seven years, the rarieties are Morello and Early May. Both are good bearers. My soil is sandy, sloping to the south. I plant in spring; gather in June; sell by the quart in town, receiving from eight to ten cents per quart. Have never grown, budded or grafted my own trees. My neighbors are growing cherries, and I consider them a paying crop in this locality. The fruit is often wormy and is stung by some insect; we spray for them.

V. E. Hathaway, Council Grove, Morris county-My cherry trees were nearly all killed in the winter of 1899 . Would plant only English Morello, Early Richmond, and Montmorency. Bring from five to eight cents per quart. My neighbors grow cherries for home use only. They are not a paying crop in this locality. The blue jays and robins trouble the fruit, but I do nothing but get mad and scold. [Try the bell cure.] Do not irrigate my trees.

Johu E. Sample, Beman, Morris county.- Ilas 500 cherry trees, planted one, two, three and ten years; they are all sour varieties. The best bearer Mr. Sample has is a variety brought by his ancestors from Scotland and planted in America in the colonial times, hefore the revolutionary war. He says no one outside of the Sample family is growing this rariety. His land is black loam, sloping to the south; planted his trees twenty feet apart. Sells his fruit while on the trees for twenty-five cents per gallon. He has grown, budded and graited his own trees. If planting over, he would set out the variety he is now growing, grafted on apricot roots; he would also put out a few Early Richmond; expects to plant 400 or 500 next spring. He says: "My neighbors grow a fow cherries; I am the only fool (") in this county." He considers them a good paying crop in that locality. Says they are troubled with no insects. Dots not irrigate his trees.

S. J. Baldwin, Seneca, Nemaha county.- I hare lired in Nemaha county, Kansas, thirty-three years. I have planted a number of orchards and about twenty or more varieties of cherries. My experience in growing cherries for market began in 1884, when I planted 100 trees-- 40 Early Richmond, 40 English Morello, 10 Empress Eugenia, 10 Louis Philippe. All did well excepting the latter; they seemed worthless and only lived about four years. The Empress fruited quite regularly, of ten quite full, but, being very early and sweet, the birds always got fully one-half, and the trees died in eight years. The Early Richmond and English Morello fruited very abundantly almost erery year; the severe winter of 1898 and 1899 killed them. In the spring of 1898 I planted 300 more cherry trees in an apple orchard; the apple trees were $32 \times 32$ feet, and cherry trees in center of square, all on south slope: they were 100 Early Richmond, 100 English Morello, and 10 each of Dyehouse, Gorernor Wood, Black Tartarian, Belle de Choisy, May Duke, Olivet, Ostheim, Montmorency, Wragg, and Jellow Spanish. The Yellow Spanish, Choisy, Tartarian and Olivet lived about seven years and produced but few cherries, excepting Tartarian, which had two good crops. Governor Wood and May Duke had fruit about every alternate year, but died at ten years. Early Richmond, English Morello and Dyehouse were all budded on Morello seedlings and produced a full crop of sprouts from roots, as well as fruit erery year; they were so injured by cold in winter of 1898 and 1899 that they are most of them dead now. The Ostheim, Wragg and Late Montmorency are still alive and very prolific; but the two former are so dwarfed by overbearing that the trees are scarcely ten feet high now, while the Montmorency trees are large and in fairly good condition and hare fruited pretty well generally. In 1892 I 
planted 600 cherry trees on new land, north slope, red subsoil, $14 \times 14$ feet; 20 Dyehouse, 80 Montmorency, 200 English Morello, and 300 Early Richmond, and got perfect stand and trees did remarkably well, most all on Mahaleb roots, and in two years about all but Montmorency were fruiting. Four years from planting I sold $\$ 100$ worth; and in 1898 I sold about $\$ 100$ worth of cherries from them; this year (1900) I had about a forty-per-cent. crop on the Dyehouse, Early Richmond, and English Morello, and about a seventy-five per cent. crop on the Montmorency, and sold from this orchard nearly $\$ 400$ worth of cherries, and trees are now in a thrifty and vigorous condition, excepting the English Morello, which were injured some by severe cold two years ago. Since 1892 I have planted in orchard about 600 cherry trees, mostly Early Richmond, English Morello, and Montmorency, and 250 Baldwin cherry, a new seedling which I introduced in 189:3, and which bears finer, larger, more beautiful cherries and is more productive than any other sort, the tree being a very hardy and vigorous grower. The original tree has fruited very regularly for about ten years and passed through the severe winter of 1898-'99 in fine condition. Hereafter I shall plant all Baldwin. Cherries ripened this year (1900) as follows: Dyehouse, June 9; Early Richmond, June 11; Baldwin, June 17; Montmorency Ordinaire, June 23: Late Montmorency, June 26; Ostheim, June 29; English Morello, July 4; and Wragg, July 7. I cultivate my trees thoroughly every year; do not prune after second year. Employ boys and girls to pick the fruit; use step-ladders; pick with stem on, in quart boxes, carried in baskets which, when filled, are placed in crates. I find a ready home market for all. I have had calls to ship, but never had but few to spare; there seems to be a growing demand for the fruit, yet scarcely any commercial cherry orchards are being planted.

C. D. Martindale, Scranton, Osage county. - I have seventy-five cherry trees in bearing, iplanted from three to fourteen years. My sour varieties are Early Richmond, Montmorency, and English Morello. I find the Early Richmond and Montmorency to be the best bearers. My soil is black bottom, gumbo and clay; it is nearly level. I plant in rows twenty feet apart; gather when fully ripe; market in quart boxes; sell at home or in Scranton at five cents per quart. Have never grown, budded or grafted my own trees. If I had to do it all over again, I would plant the varieties I am now growing. I would plant nearly on top of the ground, and cultivate well while young. My neighbors grow only cherries enough for their own use. I consider them a good paying crop in this locality. Have not had much trouble with insects. Do not irrigate my trees, but have a large pond near them.

F. T. M. Dutcher, Phillipsburg, Phillips county.-- I have about forty cherry trees in bearing, planted from two to fifteen years. The varieties are, sour, Richmond, Dyehouse, and Leib; semiacid, Montmorency and Ostheim. Of these the best bearers are Richmond and Morello. My soil is sandy loam, nearly level. I plant sixteen feet apart; gather them from June to September; market at home. Have never grown, budded or grafted my own trees. If I had it to do over again, I would plant Richmond, Morellos, and Dyehouse. Would get my trees from some good nurseryman. My neighbors grow cherries. I think them a good paying crop. Am troubled with no insects. Spray my trees. Irrigate sometimes.

Dr. James Myers, Hutchinson, Reno county.-.-I am most familiar with Early Richmond and English Morello. My opinion is that they only will pay to plant in this section of the country. Many other varieties do well in Eastern 
states, but are of little value in the West, especially in the Arkansas valley. My experience with the two varieties referred to has given good satisfaction. I planted 100 of each kind, Early Richmond and English Morello, about ten years ago. The second year they commenced bearing and have fruited every year, with one exception, since, and that was not a total failure. My cherry orchard is on high land, that is, it is forty feet above the river-bed, but I have known the same varieties to fruit equally well on bottom land. I assert that no fruit can be raised in this country with less labor and more profit than cherries. As to which variety I consider best, if I were to plant but one tree, it would be Richmond, but if I should plant more than one, half would be Morellos. The Richmond is a much larger and hardier tree, and lives longer. The fruit is more desirable for canning. Some object to it because it adheres to the stone, but that is an advantage in shipping. The Morello is not of so fine a flaror, is much easier to pick, and parts more readily from the stone; it is also a prolific bearer, and nerer ceases bearing until dead. My trees have borne as much as five crates each. I have always found a good market at home, at never less than $\$ 1.50$ nor more than 82 per crate I would earnestly recommend the planting of larger numbers of cherry trees in our state.

John Hinds, Olcott, Reno county.- Have a fow Early Richmond cherry trees, just beginning to bear. My soil is a black loam with clay subsoil. If planting over again, I would plant only Early Richmond; think spring planting best. I consider them a good paying crop. They are troubled with a web-worm; we do nothing for them. Do not irrigate my trees.

M. L. Wells, Smith Center, Smith county.-Have fifty cherry trees in bearing, planted seven years, on clay loam resting on yellow silt, sloping to the east. Plant sixteen feet apart. Sell the fruit in the orchard, receiving five cents a quart. Hare never grown, budded or grafted my own trees. If planting over, I would put out Early Richmond and some others, in dead furrows, and harrow, cultivate and hoe of ten, nerer mulch; leave tops thick. My neighbors grow some cherries. I consider them a good paying crop in this locality. They are troubled with the curculio, which I rub off. Do not irrigate my trees.

D. M. Ldams, Rome, Sumner county.-Have eight cherry trees in bearing, planted ten jears. They are Morello and Early Richmond; the Richmond is the best bearer with me. My soil is prairie, sloping to the southeast. Grow them for home use only. They are troubled with no insects, but the birds get most of the fruit. Do not irrigate my trees.

E. K. Wolverton, Barnes, Washington county.- Hare sixty Early Richmond chr'!/ trees in bearing, been planted twenty-five years. My soil is high clity prairie, haring a northern aspect; planted twenty feet each way. Sell the fruit in Barnes and Greenleaf, receiving six cents per quart. Hare grown, budded and grafted my own trees. If planting over, I would put out none but Early Richmond, budded on Mahaleb roots, $20 \times 20$ feet, on high ground, as they are better than the English Morello; other kinds do not bear well. My neighbors grow a few cherries. Do not irrigate my trees; it is not practicable.

C. H. Taylor, Eskridge, Wabaunsee county.-I have 100 cherry trees in bearing which have been planted ten years. They are Early Richmond and English Morello, both good bearers. My soil is a clay loam, sloping to the north. 
Planted my trees ten by twenty feet. Market the fruit in half bushel baskets, at home and in Topeka. Receive $\$ 2$ per bushel. I always grow, bud and graft my own trees. If planting over, I would set out English Morello, worked on Morello roots, set in deep, rich soil, and thoroughly cultivated. My neighbors grow but few cherries. I consider them a good paying crop in this locality. They are not troubled with insects. I do not irrigate my cherry trees.

Alexander Spiers, Linn, Washington county,-Have about 100 cherry trees in bearing, which hare been planted from five to fifteen years; the varieties are Early Richmond, Common, Black and English Morello; the English Morello is a rapid grower but poor bearer; the best for bearing and quality of fruit are Black Morello and Early Richmond. My soil slopes towards the southeast; plant twenty feet apart; sell the fruit in the orchard, receiving from five to ten cents per quart. If planting again, I would set the same varieties I have now, excepting the English Morello, and would cultivate and take good care of them, and would get good returns. My neighbors grow cherries. I consider them a good paying crop; they are troubled with no insects. I do not irrigate my trees.

IV. D. Cellax, Edwardsville, Wyandotte county.-I have 600 cherry trees, planted from five to nine years; they are Early Richmond, Dyehouse, English Morello, Ostheim, and Montmorency; of these I find the Early Richmond and English Morello to be the best bearers. My soil is clay, with a clay subsoil, sloping towards the east and south. I plant $15 \times 25$ feet; gather fruit in quart boxes, and market in twenty-four-quart crates. Sell in Kansas City, and western Kansas and Colorado towns, receiving, usually, from one to two dollars per crate. I have grown, budded and grafted my own cherries. If doing it over, I would plant Early Richmond and English Morello, $15 \times 20$ feet. My neighbors grow a few cherries. I consider it a fair paying crop. The curculio trouble them; we do nothing for them.

Maı. F. Holsinger, Rosedale, Wyandotte county.-Experience says, plant only the Morello varieties, if you would succeed. How much disappointment has resulted in trying to raise the Dukes and Bigarreaus; an impossibility in our climate. "Why?" do you ask? My answer would be, inclemency of winter, and the occasional drought of summer. Be the cause what it may, any attempt must end in disaster-and there you are. Confine your efforts to the Morello and you may have a meed of success. True, the cherry is not a long-lived tree, and disappointments await you even here. If you are guided by the best advice you can still hope for success. In the selection of a location for an orchard, choose only a well-drained soil. The cherry must have dry feet. Any location inclined to be wet must end in failure. Varieties are the next consideration. Of the many Morellos, Dyehouse, Early Richmond, Montmoreney, English Morello and Wragg are the best with me. There are new varieties yet not sufficiently tried to warrant their recommendation. The cherry, like other fruits, makes it growth early in the season. The first six weeks of summer is the time. In this time too much cultivation cannot be given. After the tree has gone into rest there is little use for cultivation. By attention to the facts given above, I have found more satisfaction in the cultivation of the cherry than from any other fruit. 
Upper figar

al Society,

Lower figur
Total bearing, . . . . 1,159,100

Not bearing, . . . . . 507,356

Grand total, . . . 1,666,456

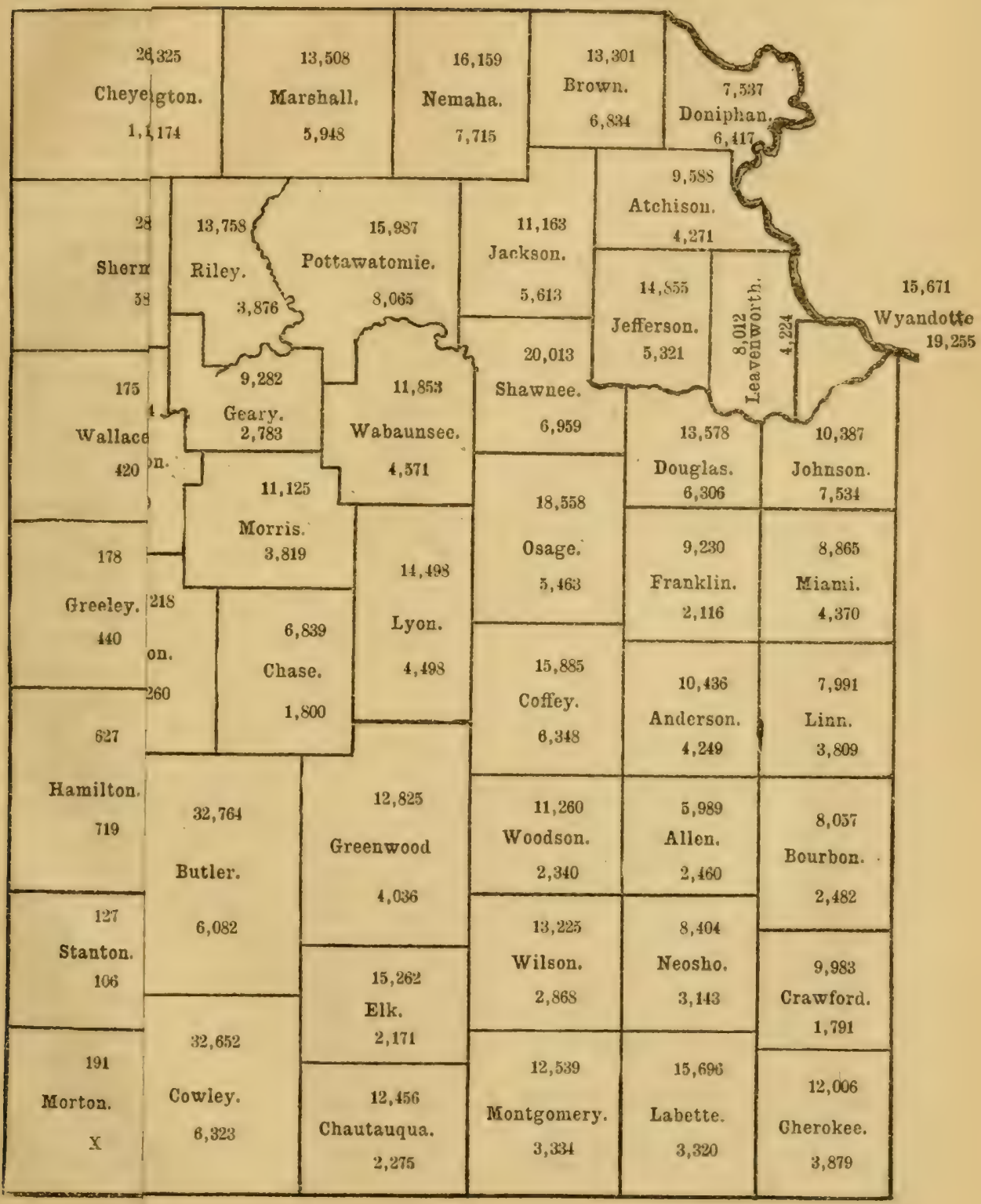



CHERRY-TREE STATISTICS, 1900.

Upper figures, bearing trees.

Compiled by WILLTAM H. BARNES, Secretary Kansas State Horticultural Society, STATE CAPITOL, TOPEKA, KAN.
Total bearing, . . . . 1,159,100 Grand total, ..... $1,666,456$

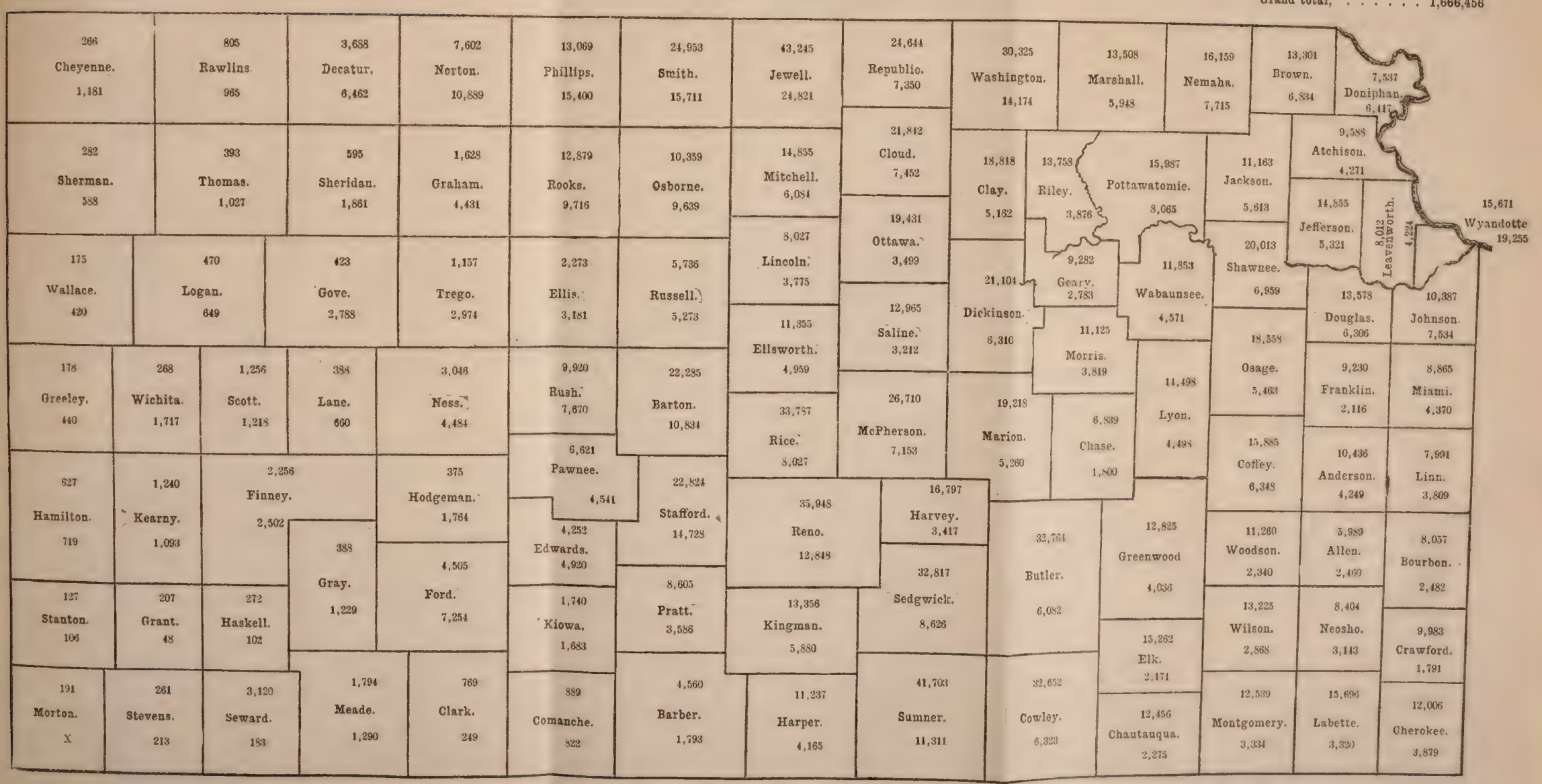





\section{A PROMISING NEW FRUIT FROM THE PLAINS.}

By Crarles E. Bessey, Lincoln, Neb.

Upon the plains of Nebraska, one of the small native shrubs which has attracted attention on account of its promising fruits is what has been known as the Sand cherry. Scientifically, it is the Prumus pumila of the botanists, and a member of the natural order Rosacea, and of the family Amygdalese. Its affinities are with the cherries and the plums, native of this country and Europe.

In Nebraska it occurs upon sandy soils north of the Platte river, beginning at about 75 or 100 miles from the Missouri river, and extending thence westward and sonthwestward to the Colorado line. It appears to prefer the sandier soils: hence its popular name'; and over the greater area I have outlined, wherever the soil is sufficiently sandy it occurs in abundance. In these portions of the country the inhabitants have for a long time been in the habit of collecting and nsing the fruit, and in some cases attempts have been made to bring the shrubs under cultivation.

The fruits are true cherries, occurring usually in pairs or threes (rarely singly) on the last year's wood. The cherries are about onehalf inch in diameter, and when ripe are of a deep purple-black color. In shape they vary from Hattened spherical (oblate spherical) to spherical, and even bluntly conical. At the base they are slightly indented, and the apex is usually marked by a slight indentation also. The stalk is slender, and from one-half to three-fourths of an inch in length. The stone or pit is slightly elongated, but little compressed, rounded on one margin, and bluntly angled on the other.

The fruits have a colored flesh which possesses in many cases a considerable astringency, but in nearly every clump of bushes one may always find some which have but little if any astringency. I have

"frequently eaten the fresh cherries while rambling over the plains, and have often found specimens which were fully as palatable as many of the cultivated cherries.

The shruh grows to a height of from one to two feet, or rarely more. Its leaves are of firm texture, oblanceolate in shape, with slightly serrated margins. Their under surfaces are whitish, and they are borne npon short petioles, and stand alternately upon the stems. Under cultivation, the shrubs are much thriftier and the leaves are larger.

From the fact that in a wild state these cherries are so large, and in many cases so palatable, $I$ am led to hope that by cultivation they may be made to yield us a new fruit for our gardens in some portions of the Northern states, especially in sandy soils. I am, moreover, 
('ncouraged in this hope by the fact that experiments upon a small scale, made by persons living in the region where the Sand cherry grows, have given results which indicate that it is readily affected by cultivation.

In closing, I need only to say that the Sand cherry of the plains, while apparently the same botanically as the Prumus pumile of the East, possesses well-marked differences: that I am inclined to regard it as at least a good geographical variety. It is from the Westem form only that $I$ hope we may derive a new fruit.

\section{DESCRIPTION OF VARIETIES.}

DYEHOUSE.

Origin unknown; was introduced by H. T. Harris, of Stamford, Ky., and was found growing in an old Morello orchard on the farm of a Mr. Dyehouse, in Lincoln county, over thirty years since; it is still grown there from suckers, and is claimed to be hardy, moderately rigorous, somewhat spreading, of the Morello type, but partakes both of the Morello and Duke in growth and fruit; a very early and sure bearer; ripens a week before Early Richmond, is about the same size, of better quality, and quite as productive. Fruit medium, oblate or rounclish oblate, slightly depressed, without suture: apex slightly depressed : skin bright red, dark red in the sun : stalk of medium length, slender: cavity rather large, smooth: flesh soft, juicy, tender, sprightly subacid, rather rich; pit very small: sometimes the stalk adheres to the pit. (Downing.)

GOVERNOR WOOD.

Raised by Professor Kirtland. Cleveland, Ohio. It deserves a place in every good collection. Tree vigorous, forming a round, regular head; very productive.

Fruit large, roundish, heart-shaped. Skin light yellow, shaded and marbled with bright red. Suture half-round. Stem an inch and a half long, in a broad cavity. Flesh nearly tender, juicy, sweet, rich, and delicious. Tery good to hest; ripe about the middle of 'June. (Downing.)

MAY DUKE.

Royale Hative, Cherry Duke of some, Cerise Guigne, Coularde, De Hollande, D'Espagne, Griotte Grosse Noire, Griotte d'Espagne of some, Griotte Precoce of some, Early Duke, Large May Duke, Morris Duke, Morris's Early Duke, Benham's Fine Early Duke, Thompson's Duke, Portugal Duke, Buchanan's Early Duke, Millet's Late Heart Duke. This invaluable early cherry is one of the most popu- 
lar sorts of all countries, thriving almost equally well in cold or warm climates. This, the Blackheart and the Bigarreau are the most extrnsively diffused of all the finer varieties in the United States. And among all the new varieties none has been found to supplant the MIay Duke. Before it is fit for table use it is admirably adapted for cooking, and when fully ripe it is, perhaps, the richest of the subacid cherries. In the gardens here, we have noticed a peculiar habit of this tree of producing very frequently some hranches which ripen much later than the others, thus protracting for a long time the period in which its fruit is in use. The May Duke is remarkable for its upright or, as it is called, frestigiate hearl, especially while the tree is young, in distinction to other sorts, which produce many lateral branches. Fruit roundish, or obtuse heart-shaped, growing in clusters. Skin at first of a lively red, but when fully ripe of a rich dark red. Flesh reddish, tender and melting, very juicy, and at maturity very rich and excellent in Havor. This fruit is most frequently picked while it is yet red and partially acid, and before it attains its proper color or flavor. It begins to color, about New York, in favorable seasons, the last of May, and ripens during the first half of June. May Duke is said to be a corruption of Medoc, the province in France where this variety (the type of all classes now called Dukes) is helieved to have originated. (Downing.)

LATE DUKE.

Anglaise Tardive. A very large and fine Duke cherry. ripening later than the May Duke, and therefore a very valuable sort for dessert or for cooking. The tree is of vigorous growth for its class. Fruit large, flattened, or obtuse heart-shaped. Color, when fully ripe, rich dark red (but at first white, mottled with bright red). Stalk rathe' slender, inserted in a shallow hollow. Flesh yellowish, tender, juicy, with a sprightly subacid flavor, not quite so sweet and rich as the May Duke. Ripens gradually, and hangs on the tree from the middles of July till the 10th of August. (Downing.)

BELLE DE CHOISY.

Belle Audegoise, Ambree de Choisy, Ambree a Gros Fruit, CHrise Doucette, Cerise de la Palembre, Cerise a Noyau Tendre, Schone von Choisy.

In our estimation, there is no cherry for the dessert more delicious than the Belle de Choisy. It comes from the village of Choisy, near Paris, where it was raised in 1760 . The habit of the tree is nearly that of the May Duke, the leaves dark, and the hearl upright. It is hardly a moderate bearer.

Fruit round or slightly depressed. Skin very thin and translueent, showing a net-like texture of flesh beneath; in color, pale amber in 
the shade, but in the sun finely mottled with yellowish red, the fruit fully exposed becoming a bright cornelian red. Flesh amber colored, very tender and melting, of a delicate sweet Havor. Stalk rather short, swollen at the upper end. Best. Middle of June or directly after the May Duke. (Downing.)

\section{OLIVET.}

A new French cherry, with the following description from the catalogue of Transou Brothers, of Orleans, France:

This sort takes a place not occupied up to the present among the list of early cherries. Nearly all the early sorts we possess are sweet amber or red varieties, with a limited fruiting seasoll. The Olivet cherry is a large, globular, very shining, deep red sort. The flesh is red with a rose-colored juice, tender, rich, and vinous, with a very sweet, subacidulous flavor. It ripens in the beginning of June, and continues until July withont losing its quality. It possesses the fertility of the best of the Duke tribe, and is perhaps the largest of that class. A friend writes that it fruited with him the past season, but being very dry the fruit was small; otherwise it sustained its foreign reputation. (Downing.)

REINE HORTENSE.

Monstreuse de Bavay, Belle de Bavay, Lemercier, Seize a la Livre. French origin, of Duke habit. Tree a healthy and handsome grower, productive, and a very desirable variety. Fruit very large, roundish, elongated. Skin a bright, lively red, somewhat marbled and mottled. Suture distinctly marked by a line withont any depression. Flesh tender, juicy, very slightly subacid, and delicious; best of its season. Ripe from the middle to the last of July.

(Downing.)

BELLE MAGNIFIQUE.

Belle et Magnifiqu', Belle de Sceaux, Magnifique de Sceaux, Belle de Chatenay, Planchoury. Tree hardy, moderately vigorous, productive; a beautiful and excellent late variety. Useful for culinary purposes. and good table fruit when pretty ripe. Fruit large, roundish, inclining to heart shape. Stalk long, slender, in an open, medium cavity. Skin a fine bright red. Flesh juicy, tender, with a sprightly subacid flavor; one of the best of its class. Ripe from the middle of July till the middle of August. (Downing.)

WRAGG.

Originated in Iowa. Medium to large; stem long; dark purple when fully ripe. A variety well adapted for the high latitude and frairie regions of the Northwest. July. (A. C. Griesa \& Bro. Nursery Catalogue.) 


\section{PROF. L. H. BAILEY ON CHERRIES.}

The oller cherry plantations of the state were seldom anything more than scattered settings along lanes and roadsides and about farm buildings. Nost of these old tree's have now passed their prime. In very recent years a new interest in cherry growing has been awakened by the demand from camning factoriess. and it has no deubt been stimulated, also, by the abundant sale of California cherries throughout the East. Sweet cherries are yet scarcely planted in western New York in orchard blocks, although there is every reison to believe that there is profit in the fruit if planters are careful to inform themselves concerning it. Sour cherries, however, are now planted to an important extent, particularly about Geneva, and the acreage is bound to increase. The pack of camned sweet cherries is still larger than that of sour cherries in western New York, in average years. The scattered plantings make uncertain crops, and canners cannot buy as confidently as they could if there were more continuous plantations. Consequently the pack varies much from year to year.

\section{RUSSIAN CHERRIES.}

Prof. F. A. Waugh gave some notes on cherries, gleaned from the work of the experiment station and from trees sent out by the station. He said that from the distribution of a miscellaneous lot of fruits, largely of Russian varieties, much the larger part of the favorable reports received were from the cherries. There were two reasons for this, both significant. First, the Russian cherries are generally the best of the Russian fruits; and second, cherries, as a class, are better able to stand the neglect of common farm treatment than other fruits. Notes were given on a large number of varieties, among which the following were favorably mentioned: Morello, Montgomery, Brussler, Braun, Bessarabian, Schatten Amarelle, and Wragg, the latter being possibly a synonym of Morello. Other's present had good success with Early Richmond, Dyehouse, and ()livet.-l'mutr'! Gentlemen's report of Vermont society.

List of varieties of the cherry voted as suitable for Kansas, in the order named, by the State Horticultural Society: Early Richmond, English Morello, Montmorency, Dyehouse, Ostheim, Wragg, Governor Wood, Napoleon Bigarreau. 


\section{GROWING BIG CHERRIES.}

A writer in the s't. James Graztte, London, tells how big cherries are obtained in that country. He says: The next and most important point of all now is, how can we improve the size and color of our cherries? We have been told, until we are weary, that the cherry tree does best in sod. Tre do not believe it, for such a suggestion goes dead against our contention that all fruit-trees are more fruitful when the surface soil above their roots is clean-unoccupied by anything srowing, whether it be grass or weeds. We admit that in the summer heat the cherry tree needs water, and a large quantity of it; also, that coolness above the roots is an advantage. We do not mind saying that sod insures coolness to a certain extent, but grass robs the soil of plant-food, and takes what the roots of the cherry trees want and should have instead.

To meet the demands of the cherry tree in summer, or just previous to and in the fruiting season, we prefer to act thus, and find the result more satisfactory by a long way: To insure coolness over the roots use a mulch of stones. They need not be too small; they will answer the purpose much better that either stable manure or sod ever can. They do not keep out the air ; they retain the moisture from the morning dews, and act most beneficially. Next feed with liquid manure now and again, after the fruits begin to swell, and then see bow they develop. Well, those who have never grown cherries before under this method will, upon testing it, be amazed at the results. One of the finest parcels of big cherries ever marketed came from trees treated thus under our instructions. When they were being put upon the cart one day a passing grower said to the owner of the fruit: "I say, guvnor, how do you grow big cherries like them?" The owner gave no reply. We give the secret away, if secret it be, satisfied that if the system is adopted it will double or treble the weight of the crop of each tree.

\section{CHERRIES IN DEMAND.}

There is a constantly growing demand for well-grown, well-colored cherries of good size, and they bring better prices in the markets everywhere than any other orchard fruit, year in and year out, with the possible exception of apples, when the labor of gathering and marketing is considered. A veteran cherry grower at a recent gathering remarked that, in his opinion, formed from extended observation, there were fewer cherry trees on the farms of the country than any other of our orchard trees of the sorts generally grown. He as. 
cribed this to the "laziness of the average farmer", who had n't energy enongh to fight off the birds that yearly ate the crop, and the trees were permitted to die out, and were not replaced." There is much truth in the statement. So long as farmers make no effort to circumvent the birds beyond the placing of a scarecrow or two in the orchards, just so long will the birds get the bulk of the cherry crop). One of the finest cherry orchards we ever saw was effectually protected from the ravages of birds in the following mamner: The trees were set in the usual way and at the ordinary distance apart, but around the entire orchard was set a double row of trees of taller growing cherries, and the fruit on these was freely given up to the birds. Not a single cherry was ever picked from them except by the birds. There was such an abundance that the birds rarely attacked the fruit on the other or inside trees. After the first season they seemed to realize that they were to have undisputed possession of this fruit. The owner of this orchard claims that he has often observed the birds Hying over his cherry orchard, but alighting only on the outer rows, the "birds" cherries." Occasionally he sees a few birds in the orchard proper, but claims that repeated close observation reveals the fact that they are seeking insects and not fruit. Other growers have tried the plan on a smaller scale, and found that it worked to perfection.

The best success with cherries is had in a soil fairly rich, but dry, or one that can be easily drained. Cherry trees are subject to but few diseases; the black-knot, which is confined chiefly to the sweet rarieties [??], being the most troublesome. In the selection of varieties the planting should be governed by the demands of the market, bearing in mind that highly colored sweet varieties sell best, although there is always a demand at fair prices for the sour surts.- lrow York Tribune.

\section{TWO POPULAR CHERRIES.}

Cherry growing is a prominent interest in western New York. The two most profitable varieties are the Montmorency and the English Morello. It is a question which is the more popular of the two. The cammers give the Montmorency the preference. Both varieties should be grown, as by the time the Montmorency is gone the English Morello is ready for market. The Early Richmond is not in much favor, being small and of poor quality. The Ostheim is very productive, but too small.

A common mistake is made of planting trees too close together: $18 \times 18$ feet is the right distance. Five cents a quart is a fair price for the fruit, and at this rate an orchard will net $\$ 100$ to $\$ 175$ a year per acre. 


\section{LARGE CHERRY TREES.}

At Monte Rio, five miles southeast of Newcastle, Placer county, California, on the place of Robert Hector. is to be found what are probably the largest cherry trees in the world. There are about fifty of these treess, which were planted in 1853). According to The Parific. Be', Mr. Hector has systematically made inquiry, whenever he heard of a large cherry tree in any place in the world, and all his investigation thus far has failed te find mpon this continent, or upon the old continent, trees as large as his own. The next largest tree he has heard of is in Buffalo, N. I. What is perhaps the largest tree in the lot is a Black Tartarian, and is seventy feet high. Tts branches spread over a piece of ground the diameter of which is between seventy and seventy-five feet, and the trunk is between ten and eleven feet in circumference. From one of these cherry trees, in one season, has been taken as high as 3000 pounds of fruit. The trees are really too large to be profitable, for the fruit has to be gathered with the aid of extension ladders securely gruyed, by men slung in swings from such ladders or the forks of the trees. The best fruit, of course, is toward the tips of the branches, and, therefore, the most diffiult to reach.

\section{HIGH PRICES FOR CHERRIES.}

A press dispatch, dated New York, May 6, reads as follows: California cherries have furnished the feature of the fruit market for the last few days, and they have, as a rule, brought excellent prices. The fruit auction company sold fifty-one boxes yesterday at auction, and they were snapped up at prices ranging from $\$ 8.25$ down to $\$ 1.75$ per ten-pound box. The phenomenal price paid for the choicest lots probably establishes a record. The same company sold twenty boxes to-day at equally fancy prices.

\section{MONEY IN CHERRIES.}

The Cloverdale liemille recently printed the following: Farley Abshire has shipped 285 boxes of cherries, each box containing ten pounds. The fruit netted him about one dollar per box. He still has about 3000 pounds of later varieties which he will dispose of to the canneries. He will realize probably $\$ 300$ from less than an acre of ground. Who says cherries do not pay? 


\section{GREEN'S BLACK TARTARIAN CHERRY.}

I have spoken in these columns about the old cherry trees standing near our house at Rochester, N. Y., which have borne heavy loads of the finest fruits regularly each season as far back as the oldest inhabitants can remember. This year these trees have been as heavily laden as formerly, and the fruit has been uniformly of the finest character and free from blemish. This year, as in former years, this fruit has been in eatable condition for about four weeks, and at the present writing, July 5, the cherries are in their prime.

We pick these cherries for market bofore they turn black, since that is the condition in which the buyers desire them. In this condition they stand shipping well and are in good demand. At five cents per pound, the fruit from these three cherry trees this season will amount to fifty dollars. At this rate, an acre of this variety would yield $\$ 1120$ gross. I have stated to my friends that if I had ten acres of cherry trees that would yield like these, I wonld need no other suurce of revenue. Cherries this year, 18:99, have sold in Cleveland at ten cents per pound wholesale. At Rochester they have been cheaper, owing to the large quantity of cherries growing in this locality.

The Mindsor cherry has fruited at Green's fruit farm this year and proved, as usual, to be a variety of extraordinary merit. It is a large cherry, almust black. It is not quite so firm as Black Tartarian, therefore, possibly, not quite so valuable for shipping; but for eating out of hand it is, if anything, superior in quality to Black Tartariun.Green's Fruit Grower.

\section{TO SPROUT CHERRY PITS.}

"Please let me know the best way to sprout plum, cherry and peach pits. I am in the nursery business on a small scale, and, although I have always put my seeds in beds in fall, have had trouble to get them to burst in the spring." $-H$. M. K., Newrille, Pa.

Our correspondent's trouble rises, perhaps, from not having the seeds moist enough in the seed-bed. If a seed-bed is too dry and not covered by snow, so that the seeds simply freeze dry, the results are not likely to be good. Stratify the seeds - that is, mix them with suil, or sand - and put into a convenient box, and bury box and all in some situation where they will keep moist through the winter and where they will freeze.well. In the spring sift out of the earth, and plant. Some prefere to go orer them by hand in the spring and crack with a light hammer any which are not sufficiently opened. This should give the desired result. 


\section{THE CHERRY ON DRY SOIL.}

The cherry tree needs a dry but rich and deep soil, with enough potash to supply the enormous demand to ripen its crop of seeds and stones. The cherry itself is mainly water, but if the stone cannot be produced the fruit is apt to rot, especially in wet weather about the time of ripening. To make cherries profitable it requires something more than to grow them. A large amount of cheap help must be near at hand. One must also be situated near a market, canning factory, or station to ship the fruit. The fruit must be picked dry and all imperfect specimens thrown out. Unripe cherries will not bear transportation as well as ripe ones; hence they must not be picked too soon. When all the conditions are favorable, there is no crop that pays better and in seasons of scarcity gives a larger profit per acre.

\section{SOUR CHERRIES IN WESTERN NEW YORK.}

The growing of sour cherries in western New York is largely confined to two varieties, the Montmorency and English Morello, and it is not yet fully determined which of the two is the more profitable in the long run. The preference has generally been given to the English Morello, as it bears younger than the other, and its dark colored and very acid flesh have made it popular with the canning fuctories. Just now, however, the camners are calling for the Montmorency in preference, for, whilst not so sour as the other in the natural state, it "cooks sour," and the Morello is apt to develop a bitterish or acid taste in the cans. The Morello is also much subject to leaf-blight, whilst the Montmorency is almost free from it ; and the Montmorency is a stronger and more upright grower. The present drift is decidedly towards the Montmorency. The two varieties complement each other, however, for the Montmorency is about gone by the time the other is fit to pick.

This Montmorency of western New York is a rery light red, longstemmed cherry, broad, and flattened on the ends, the flesh nearly colorless and only moderutely sour. The tree is an upright, vase-like grower.

Amongst the Griottes, or red-juiced cherries, three have gained some notoriety in western New York-the Ostheim, Louis Philippe, and Morello.

The Ostheim is a very productive variety, ripening about a week after Early Richmond, but it is too small and too early to be valuable for general cultivation here. 
The Morello, varionsly known as English, Large Dutch, and Ronald's Morello, is nearly two weeks later than Montmorency, a bushy and finally a drooping grower, with medium-sized, roundish or roundcordate fruits, which become red-black when fully ripe. Flesh very dark, much sourer than the Montmorency. In western New York the Morello harvest hegins from the 8th to the middle of July.

\section{SWEET-CHERRY INDUSTRY.}

Unlike most other fruits, the sweet-cherry industry has never attained a prominent position in westem New York. There is not an orchard of it west of Albany, so far as I know. Along the Hudson, however, there are three or four orchards. It is on the few trees scattered on every farm throughout the state that the cherry crop is mostly grown. It should not be thought however, that the smallness of the industry follows from a lack of appreciation of this most luscious fruit. It is due to the fact that the cherry is a most difficult crop to handle and market successfully, because of its exceedingly delicate character, and the fungus, which causes brown rot, which spreads so rapidly on the ripening fruit, that the promising crop of to-day may be half rotted to-morrow. The comparative ease of handling and marketing grapes, apples and pears make those fruits universally popular. The cherry is one of the most popular door-yard fruits, and its hardiness, its vigorous upright form, which often attains the height of forty to fifty feet, and its luxuriant, soft, drooping foliage, its hardiness, and the fact that it bears annually when properly treated, make it a most desirable tree for ornamental and fruitbearing purposes. The tree starts very early in the season and most varieties are harvested by July 1 , thus leaving the trees sufficient time and energy to perfect fruit-buds for the coming year; and if the wood is well ripened in the fall the mereury may fall to twenty degrees below zero without injury to the coming crop. There seems to be much inquiry among fruit-growers and farmers regarding the care of cherry orchards, the most desirable varieties, the diseases, the methods of handling and marketing the crop. As these matters are more fully understood, the cherry industry may be expected to reach a prominent position among the other horticultural inclustries.Professor Bailey's Bulletin. 


\section{DRYING CHERRIES.}

In picking cherries for the market they should never be taken from the tree right after a rain. Many of them are cracked open, or ready to, and these will spoil the whole crate. Let the sun shine on them again before picking, and even let the birds pick the cracked cherries for their breakfast; these they always prefer. After the sun has been on them a short time the surplus moisture will be dried and they cun be picked for market. After picking, rigidly sort, for the best pickers will put in overripe, decayed and stemless fruit. These help rot the others and thus labor is thrown away. Put only the finest cherries in each basket, all of about the same ripeness and size. Many placed on sale show one-half of the cherry dead ripe and the other half green. The appearance, if nothing else, is against them. It is always better for the trees and profitable to the owner to have all the fruit picked from the trees. There will be times when it will hardly pay to ship them to market, and best to dispose of them some other way. Make a platform of boards, in the sun, and dry the surplus. It is easy to pit them, and in half a day bushels could be spread out to dry. Many overripe cherries, that cannot be shipped, can be dried, and the surplus thus preserved. Dried cherries are quoted in the markets now at nine and ten cents per pound, and good qualities bring even more. There is always a demand for them in the winter; they make excellent pies, puddings, and preserves. If there is no other market, many can be eaten at home. It is by means similar to this that the cherry crop must be disposed of ; it prolongs the season and brings a fair profit to the owner. Preparations for drying should he made before the crop is ripe, for then other work will demand the attention.-S. W. Chambers, in American Cultivator.

\section{HOW TO SAVE YOUR CHERRIES.}

Persons having a few trees of cherries they would like to have get thoroughly ripe, and prevent the birds gretting all of them, can clo so by hanging a bell in each tree- a cow-bell, shcep-bell, or an old school-hell, any of them will do; and they are generally lying around farm-hunses. Tie long pieces of binder twine to the handle of each bell, and hring the other ends all together in the direction of the house, and tie all to one strand of twine, so that by pulling it all the hells will ring. Have this line long enough to tie the other end to a nail near the kitchen door, or some convenient place where it can be given frecuent pulls. When you ring the bells the birds will leave 
in short order. Of course they will return, but you must give them another ring, and keep it up frequently till the cherries are ripe, beginning when the birds begin on the cherries. We have succeeded numerous times in this way, even when the trees are more than twenty rods from the house. Try this plan. Do not shoot your good friends, the birds.

\section{THE CHERRY A NOBLE FRUIT.}

This noble fruit has for a long time been kept in the background for the growing of the apple, peach, etc., on account, I suppose, of the inability to market the crop to good advantage; the main reason for which, no doubt, is in not selecting varieties which ripen in succession. The question of growing the cherry into a tree is far less important to the orchardist than the proper selection of varieties, and the care and management of it after it is planted where it is to remain. Within the past few years a number of new varieties have been brought before the public, but most of them have proved to be wanting in hardiness or quality, and were discarded. The Montmorency is perhaps an exception, the tree being hardy and the fruit somewhat better than the Early Richmond; yet we consider the Early Richmond the best allround cherry, with Montmorency a close second, and have therefore divided our orchard between these two, in order to have a succession of ripening, thus affording greater ease in disposing of the crop. Have tried May Duke, Ostheim, Wragg and Dyehouse without success.

\section{GRAFTING THE CHERRY.}

By Prof. N. E. HAnsen, Ames, Iowa, in Nebraska Horticultural Society report.

Root-grafting of the cherry in the house during winter is considered difficult by many, but it has been practiced at the Iowa Agricultural College, at Ames, every winter for many years, with good success. For plums, one-year seedlings of our native northern plum, Prunus americunce, are used, which are grown from pits of the best cultivated varieties of the same species, such as Wyant, De Soto, and Wolf. Seedlings should not be grown from seeds gathered indiscriminately in the woods, but only from trees growing good-sized fruit. It has been found such seedlings are better and more uniform, and there is less liability to injurious influence of stock on scion. In the last two or three winters we have also used Marianna stocks, grown from cuttings, for root-grafting, and secured a good stand. For cherries, imported Mazzard stocks are used. Both plum and cherry stocks are packed away in thin layers, with earth between the layers, in a 
cool cellar. Only one scion is used to each root; piece-root grafting does not give a good stand with the plum and cherry.

The method used is that known as "side-grafting" or "wedgegrafting," and the scion is inserted at the collar. By collar, is meant the neck or line of junction between the stem and root. The scion is 'nt wedge shaped at the lower end with a perfectly true and straight cut, so it will fit snugly into the incision in the stock. The length of this wedge cut. one and one-half to two inches, depends on the size of the scion, a large scion requiring a long cut. The scion shonld contain about four buds besides the bud at the base or beginning of the wedge cut. The stock should have a ring of bark left above the incision. No wood is removed from the incision - simply a lateral cut long enough to receive the scion, cutting about two-thirds through the stock; and care is exercised to cut across the grain slightly, so as to aroid splitting the woor. Use a sharp, thin-bladed knife: a common shoe knife does as good work as any. If the incision in the stock is properly made, the scion will be held very firmly by the natural spring or elasticity of the wood. In cutting the scion, make the inside of the wedge ent thinner than the outside, so that the scion will fit neatly: but this is often overdone, so that there is too great pressure on the cambium layer (layer between the wool and bark) for j)roper union. So, make the inside of the wedge cut ver'y slightly, if at all, thinner than the ouiside. The vital point to be noticed is that the inner barks of the scion and stock must be brought together, so the union can be made when growth begins.

Some device must be used to hold the seedling firmly while making the incision. The most convenient one for the grafting bench is simply half of a barrel stave fastened at the further end with a leather hinge. At the end next the grafter a strong wire is fastened around and passed through a hole in the grafting bench and fastened to a treadle below. In this mamner the seedling is held very firmly. To prevent injury to the seedling, put a strip of lenther on points of contact on inner edges of the stave and on top edge of grafting bench.

Three men work best together -- two to graft, and one to wind, wax, and pack. After grafting, the point of union is wound three or four times at top and bottom with waxed thread, and alcoholic plastic applied with the thumb and finger. The plastic must also be applied to the tip of the scion to prevent drying out. The grafts as waxed are run through sand so they will not stick together, and then packed away in a mixture of about one.half sand and one-half earth, in boxes, in the cellar or cave, same as apple-root grafts, keeping the temperature as near freezing as possible, to prevent injury from the graft-box fungus. Even if frozen in the boxes no harm is done. The waxed 
thread is made of No. 18 knitting cotton run through melted wax onto an open drum, or hollow cylincler of wood, with a crank handle attached. The wax is softened with a little linseed oil.

Recipe for alcoholic plastic: One pound white resin, one ounce beof tallow, one tablespoonful turpentine, five or six ounces alcohol. Melt resin slowly: take from firo and adel tallow, stirring constantly. When still cooler add turpentine slowly, then alcohol. Wood or methyl alcohol is cheaper than common alcohol, and, as tried at the college, seems to answer the purpose equally well. It is poisonous, and should be so labeled. If the plastic becomes too stiff to work well, put ressel in a vessel of hot water and add more alcohol. The plastic should be of the consistency of thin syrup in order to work well.

The scions are kept in boxes of dry forest leares in the cellar; the leaves contain sufficient moisture to ke(p) the scions in good condition. The scions must be watched and not allowed to get either too plump or too shriveled, but better a little shriveled than too plump.

With all stone fruits side-grafting is much preferable to whipgrafting. By comparing the two methods it will be seen that the side-graft has two surfaces on the scion to unite by, while the whipgraft has but one. In the nursery the side-graft can be used in the spring in crown-grafting seedlings, where the bud failed the preceding autumn. Side-grafting is also the best for all top-grafting of plum and cherry. For outdoor work, the vessel containing the alcohol plastic is set in the top of a large lantern-shaped tin box with a lamp inside. The terms "top-grafting" and "top-working" are the same, the latter being more generally used in nursery work. It is most convenient for two men to work together - one to graft and the other to apply the plastic.

Plums and cherries should be grafted before there is the least sign of the buds starting; hence, pleasant days in March shonld be improved in this manner. However, they may be grafted after the buds have started, provided that the scions have started equally as much. But in general it is best to graft the stone fruits early, before the buds have started. No waxed thread is used in top-grafting. After inserting the scion, apply the alcoholic plastic to the point of union and wrap with a strip of old, thin, white muslin. The muslin will acthere to the slightly warm plastic and no thread is needed for tying. The exposed tip of the scion must be touched with the plastic to prevent drying out. The "robbers" or sprouts appearing on the stem below the graft must be removed from time to time as they appear, so the scion will have a fair chance for vigorous growth. If this is not done 
the scion will make but a feeble growth, or perish altogether, from lack of nutriment.

In top-grafting young trees in the nursery it will not do to strip all the leaves appearing on the stem below the graft. All the buds for a short distance just below the point of union should be allowed to expand, in order to "draw up the sap" and cause vigorous growth. If these buds push too strongly, keep in check by pinching. As the graft grows these leaves on the stock can be gradually remover, beginning with the buds next to the graft. In top-working plums and cherries, the outer bark often becomes tough and dry, so it will not expand to make room for the deposit of new wood in.June. The graft is then in danger of perishing from tight lacing, and the corset strings must be cut. Do this by slitting the bark lengthwise in several places, taking care not to cut into the wood, as this is apt to cause gumming.

\section{THE CHERRY ORCHARD.}

A strong, loamy soil, and one which is retentive of moisture, is the most suitable for sour cherries. The fruit contains such a large amount of water that it is necessary to save the moisture of the soil to the greatest possible extent. Dry clay knolls produce cherries of less size and of inferior quality than the moister depressions between them. Very early and thorough cultivation is essential to this conservation of moisture, and the tillage should be continued at frequent intervals until the fruit is about ripe. In order to be able to cultivate the soil at the earliest moment in the spring, the land should be either naturally or artificially well drained. The crop of even the Morellos is off the trees in July, so that there is abundant opportunity to sow a catch-crop on the orchard for a winter cover, if the manager so desires. A variety of plants may be used for this cover. The best is probably Crimson clover, particularly if the orchard needs more nitrogen or growth; and if American-grown seed is sown by the middle of August in a well-prepared soil, the cover will probably pass the winter safely. Other plants which may be used for cover are rye, winter wheat, vetch, field pea, sowed corn, millet, and buckwheat. Of these, only the two first will live through the winter and grow in the spring. In using cover crops which survive the winter, it is very important that they be turned under just as soon as the ground is dry enough in spring. As soon as the plant begins to grow it evaporates moisture and dries out the soil; and it is more important, as a rule, to save this moisture 
than it is to secure the extra herbage which would result from delay. This is especially true with the sour cherry, which matures its product so early in the season, and which profits so much by a liberal and constant supply of soil moisture. Plowing can also be begun earlier on land which has a sowed crop upon it, because of the drying action of the crop. The fertilizers which give best results with other orchard fruits may be expected to yield equally good returns with the cherry.

It is an almost universal fault to plant cherry trees too close together. The Montmorency should not be planter closer than eighteen feet each way in orchard blocks, although it is often set as close as twelve feet. The English Morello is a more bushy grower and may, perhaps, be set as close as sixteen feet with success; but I believe that even this variety should stand eighteen feet apart. The sour cherry orchards in western New York are yet so young that the evil effects of close planting have not yet been made apparent. I find, however, that nearly every shrewd orchardist who has had experience with these fruits is convinced that the general planting is too close.- From Cornell, Bulletin.

\section{WHERE TO PLANT CHERRIES.}

The two great classes of cherries differ widely in their adaptability to the conditions of the climate and soil. The sour class is far the most hardy of constitution, both as to heat and cold. They also flourish on more varieties of soil than the sweet class. The soil and climate that suit the sweet cherries are good for the sour kinds too, but not vice versa.

The sour varieties delight in a rich loamy soil that has considerable clay in it and one that does not easily dry out; however, the soil should not be wet. The sweet kinds require a looser and more mellow soil; one that is sandy or gravelly is good if well enriched, but it may be made too rich, and thus induce too late and tender growth. The cherry should mature its wood early.

The sour cherries will grow in almost any climate that will suit the apple, but on the prairies of the Northwest it is only some of the hardiest Russian kinds that can endure the rigors of the winter. and these cannot always succeed. The sweet class find their most congenial climate in North America in the milder regions of Oregon and Washington. In California they also do well. In the foot-hills of the Blue Ridge and Alleghany mountains and along the Hudson river they do best in the Eastern states. In the Mississippi valley they are liable to die early from the effects of the violent changes of 
temperature. A mild, equable, moisi climate suits them best, but not a hot one.

Twenty-five or thirty feet is none too far for the sweet kinds, but the smaller-growing Amarelles and Morellos will do very well at "ighteen feet, or even closer in some places where the soil and season do not stimulate a vigorous growth.

It is useless to expect to grow cherries profitably either for market () clean cultivation. The soil should be kept as clean as a garden up to the time the fruit is ripe; soon after that their wood is mature and cultivation may be stopped. If the trees lack vigor, a catch-crop of Crimson clover, cow-peas, buckwheat or even rye may be sown, but it must be turned under very early in the spring, and the stirring of the soil resumed. The cherry is very sensitive to severe pruning, and the trees should be well looked after when they are young to get them headed low enough for convenience and properly formed; then little will be needed afterwards. The cutting of large branches is very dangerous at any time.

The universal plan in gathering cherries is to leave the stems attached to the fruit, except, rarely, for local sale or home use. Small packages have proven decidedly more profitable to carry them to market than large ones. Quart berry boxes and shallow trays put up in crates are better than grape baskets, according to the latest experience.-Prof. II. E. Van Deman.

\section{THE DYEHOUSE AND EARLY RICHMOND CHERRIES.}

The difference in the fruit of the two varieties is not a great deal until both are ripe, though Dyehouse generally ripens a week or ten days in advance of Early Richmond. But the fully ripe fruit of Dyehouse is superior to the fully ripe fruit of Early Richmond. Another difference, as noted by Professor Powell, of the Delaware station (bulletin No. 35), is in the juice of Dyehouse being somewhat dark colored, while that of Early Richmond is colorless. Both varieties are profuse bearers, and Dyehouse is probably the earliest bearer of all fruit-trees: young trees, two years old, quite frequently bear in the nursery rows. Both varieties are valuable for localities in which the sweet cherries are not generally successful; and Dyehouse is valuable for any locality and in any collection, considering its excellence for pies, for canning, and, when fully ripe, for eating right from the tree. It has also the smallest pit of all cherries.

Dyehouse, as many of our readers know, originated in central Ken- 
tucky, an accidental seedling in the orchard of the person whose name it bears. This was years ano, when the people there had heard little or nothing about budding or grafting, and increased the stock of their favorite and never-failing cherry by sprouts dug up from the roots of the parent tree. And some prefer these spronts still, though the reason of their preference is hardly clear. Finally, after thirty years of continuous bearing - every year with one exception, when a late frost destroyed the young fruit, then about the size of peas-Mr. Henry T. Harris, a person who had experience with choice fruits, came across it and introduced it to the public.

Since that time--over twenty years ago-it has demonstrated its excellence in various parts of the country, North as well as South, East and West, even in Minnesota and Canada.

There is one peculiarity attending the propagation of the trees of Dyehouse: the buds frequently do not succeed, failing to become attached to the stock, and consequently dying. Why this is so is difficult to say, but it affects only the nurseryman.

\section{CLASSES AND VARIE'TIES OF CHERRIES.}

Of cherries there are at least three distinct classes: the Morellos, Dukes, and Hearts. The MLorellos are all sour and the trees flourish and bear in almost every part of the country. The Dukes are tart in flavor and the trees are quite sensitive to climatic variations, and require a region where the changes are not severe, being neither very hot in summer nor very cold in winter. The Hearts are still more difficult to grow, exeept where the climate is peculiarly suited to them, which is on the Pacific slope, in the Piedmont sections of the Appalachian mountain ranges, and in the vicinity of the great lakes. In those places they seem to Hourish, especially in Oregon and California, where the most productive trees and the largest and most perfect fruit are grown.

Morellos: Dyehouse, Richmond, Montmorency, Philippe, English, Wragg. Dukes: May Duke, Late Duke, Choisy, Olivet, Hortense, Magnifique. Hearts: Black Tartarian, Napoleon, Tartarian, Mercer, Windsor.

Commercial cherry growing is not practiced by many this side of Californ ia and Oregon. There is opportunity for much more in that line than is done in the Eastern states; especially is this true of the Heart and sweet varieties, which are well suited to the certain sections already mentioned. 


\section{CHERRY ORCHARDS FOR PROFIT.}

It is the opinion of Professor Bailey that cherry culture has not received the attention it deserves in this state. It is his opinion that cherry orchards can be made exceedingly profitable here. Professor Bailey laments the fact that there are scarcely any cherry orchards in New York state, and that cherry growing as a business is scarcely known here. He can see, however, a growing interest in cherries, occasioned by the success of California fruit-growers in marketing large quantities of Californin cherries in our large cities and towns at profitable prices, after paying enormous freight-charges for 3000 miles shipment. In California orchards of 50 to 100 acres of cherries are not uncommon, but who ever heard of such orchards in the Eastern or Mirdlle states; and yet we have land and climate particularly adapted to cherry growing.

Cherry growing in the Eastern and Middle states is often confined to a few straggling trees in the door-yard or along the fence-rows, where they receive no cultivation; the owners at no expense for the cherries thus produced. When the fruit ripens the owners are not informed as to the proper methods of gathering, marketing, or the best packages. The cherries are hastily and roughly plucked from the tree, often with stems pulled out of the fruit, thrown into large baskets, and sold promiscuously without grading, and dumped into the market in this unsightly conditition, to bring whatever the shipper may offer. The shipper who buys these ill-assorted and poorly gathered cherries immediately assorts the fruit, packing the best in boxes, similar to those used by the California growers, selling the second grade to local pie makers, and throwing the culls away. Surely all this work should be done by the fruit-grower. If he should properly manage he would realize twice as much profit.

There is a growing demand for cherries for eating out of the hand, for pie making, and for canning. An acre of cherries under cultivation will yield an enormous quantity of fruit. This fruit need not be gathered the day it ripens. The Black Tartarian cherry on my place at Rochester hangs on the tree a month. And yet there is a time when cherries for market should be picked, and that is before they become fully matured or colored.

Many people are deterred from planting cherry orchards owing to the fact that considerable help is necessary to gather a crop of cherries, and yet there is scarcely any locality where sufficient help cannot be secured. All such enterprises as this require business ability in the management of labor, in the production of fine fruit, in suitable packages, and preparation for market. But I doubt if any enter- 
prising young man would hesitate to plant a cherry orchard for this reason. One of the good things of our fruit-gruwing is that it develops business ability.

\section{A BIG CHERRY TREE.}

In California there is a Black Tartarian cherry tree, thirty-five years old, that is probably the most productive tree of the kind in the world. The body of the tree four feet from the ground is eleven and one-half feet in circumference, and in one year one and one-half tons of cherries were marketed, and besides considertble fruit wis used by the owner and much was given away. The quality of this cherry is excellent. We get this item direct from Rev. R. M. Tmmell, recently from California, who thinks this cherry would do well in this Ozark country.

\section{CHERRIES IN THE WEST.}

There is no fruit that gives mure satisfaction to the grower than the cherry. True, the sour cherries are the only ones to plant. The sweets and Bigarreaus do not succeed in our climate. To plant them is sure failure. I know this by experience, as I have planted hundreds without ever seeing them ripen fruit.

With the sour varieties it is different. I believe there is no place where they do better than here. We have at this time over 4000 planted and are still planting. Of varieties there are a number, and to secure a continuance I would name Dyehouse, Early Richmond, Montmorency, Ostheim, English Morello, and Wragg. All are good and early bearers.

Cherries require dry, good soil. Unless you have well-drained soil it will cause you disappointment. On the proper soils the trees are as long-lived as the apple. I know some trees planted here thirty years ago that are still productive. Do not cultivate after the trees are well established. The fruit sets and ripens in a stifl blue-srass sod as when cultivated. We simply mow the grass, allowing it to rot on the ground. One grent mistake in growing cherries is in healing the trees too high. I mack this mistake with the firet 300 ) trees, set in 1876. It requires long ladders to pick the fruit. We now try to keep them down to bush form. It is so much easier to pick the fruit and far less liability of breaking the irees. I have named six varieties in their order of ripening. There is a German cherry here earlier than Dyelouse by at least four days. We call it "Jerusalem." It may be irlentical with Early Jirivllo. A MLr. Saur brought it from "fither- 
land." Dyehouse originated in Kentucky, and is a week earlier than Richmond. I think it better-its seeds are smaller. The Wragg is an Iowa product, being hardy and bearing young. I had one-year-old trees ripen this variety last year. I think the Dyehouse and Wragg indispensable, as the latter is late and, holding fruit well, it lengthens the season about two weeks.--Westem Fruit Grower.

\section{CHERRY-ORCHARD EXPERIENCE.}

Cherries are usually set when $t$ (w) years old from the bud. The sour varieties are propagated both upon Mazzard and Mabaleb stocks, chiefly the latter, but the comparative merits of the two are not determined. The tops are started about three or four feet high, and the subsequent pruning is very like that given the plum. If the young trees make a very strong growth and tend to become top-heavy, heading in may be practiced; but this operation is not considered to be necessary after the trees begin to bear. Cherry trees require less attention to pruning than apple trees and peach trees do.

The English Morello will bear a fair crop the third year after setting, if two-year trees are planted. The Montmorency is a year or two later in coming into bearing. The Montmorency, partly because of its larger growth, produces much more fruit than the other, when it arrives at full bearing. Individual trees of Montmorency at six years and upwards may bear from thirty to seventy-five pounds of fruit; but eight to ten tons of marketable fruit are an excellent crop on an orchard of 800 Montmorencys eight years planted; that is an average of twenty to twenty-five pounds to the tree. The Morellos, hecause of their lark color, usually sell better than the Montmorency in the open market, but the reverse is now generally true if the crop is sold to canning factories, This year the factories have paid five and six cents a pound for Montmorencys. It is easy to figure the proceeds of an acre. At $18 \times 18$ feet, an acre will comprise about 130 trees. If, at eight years, they yield twenty pounds each, the crop' would amount to 2600 pounds, which at five cents means $\$ 130$. This is a conservative estimate. Benjamin Kean, Seneca, has 200 Montmorency trees six years set. He has had three crops, one of 1400 pounds, one of 3000 pounds, and one 3100 pounds. He sold his entire crop this year for five cents, making a gross income of $\$ 155$. His trees are set $10 \times 12$ feet, which allows about 360 to the acre. In other words, a crop which sold for over $\$ 150$ was taken from less than two-thirds of an acre. The soil in this case seems to be unusually well adapted to this cherry and the crops have, therefore, been excellent; but, on the other hand, part of the crop was destroyed this year 
by the curculio. C. H. Perkins, Newark, has thirty-five trees, eight and twelve years old, all Montmorency. "They bear," he writes, "from 2000 to 3500 pounds of cherries per year, and the average price that we get for them is six cents. They net us from $\$ 100$ to $\$ 175$ a year. They are the most regular and sure cropper of any fruit we have ever tried to grow, and the fruit always finds a ready market at a good price." The Maxwell orchard, at Geneva, yielded over eleven tons of Montmorency, this year, from 800 trees.-Ithar $(,, N$. Y., Bulletin.

\section{PROFITS OF THE CHERRY CROP.}

The profits from the cherry industry depend mainly on the effor of the grower in producing first-class fruit and in placing it on $t$ market somewhat after the directions given. In 1888 an acre of cherry trees, eighteen years old, including Black Tartarian, Black Eagle, Napoleon Bigarreau, Elton, Yellow Spanish, and Downer's Late Red. netted $\$ 380$, while an acre of rye netted eight dollars.

The following sample figures are taken from sales from the orchard this season, trees twenty-five years old:

Five trees of Robert's Red Heart averaged 280 pounds per tree; the

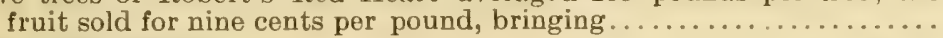
The expenses were:

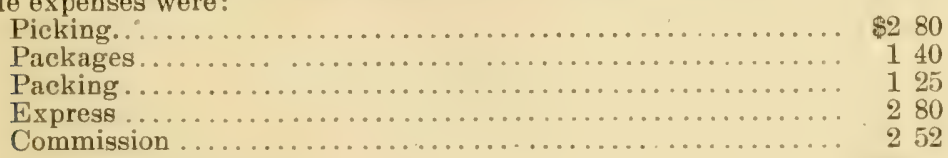

Net profit per tree........................... $\$ 1443$

One tree of Robert's Red Heart yielded 416 pounds, which sold to retail dealers at ten cents per pound at the express office ............... Expenses:

Picking ................................... $\$ 116$

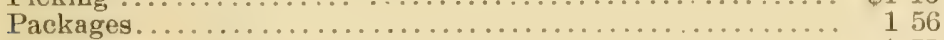

Packing ................................... 1 75

Net profit . . . . . . . . . . . . . . . . . . . . .

One acre of Windsors, containing seventy trees, eight years old, yielded eighty-four pounds per tree- 5880 pounds - which sold at ten cents

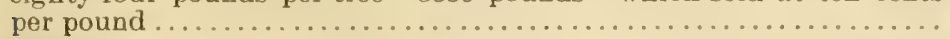
Expenses:

Picking . . . . . . . . . . . . . . . . . . . . . . . . . . $\$ 5880$

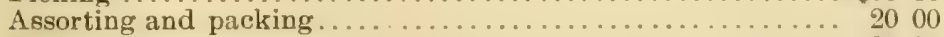

Packages..................................... 3000

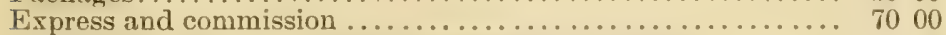

Cultivation (plowed once and harrowed six times)......... 350

Fertilizers ( 300 pounds potash, 100 pounds bone, 15 pounds Crimson clover seed $) . . . \ldots \ldots \ldots \ldots \ldots \ldots \ldots \ldots \ldots \ldots . \ldots \ldots$

Interest on land, at $\$ 150$ per acre............................ 900

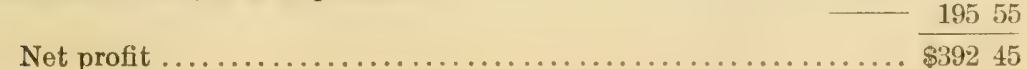


All these figures refer to sales in the open market. There is a good demand for sweet cherries for canning factories. The canners generally prefer the "white cherries"-those with a white juice and rather light-colored skin. The crop of sweet canning cherries in western New York appears to be growing smaller, and the California product has driven out much of the home-made goods. One of the best informed canners in the western part of the state writes as follows concerning the sweet-cherry pack: "Up to six or seven years ago, we handled from fifty to one hundred tons annually. The cherry crop appears to be growing smaller each year, and to be deteriorating very much in quality." The canners tell us, in general, that when they can get good fruit they have no trouble in making a salable product.-From Cornell Bulletin.

\section{FOUR PROFITABLE CHERRY TREES.}

When we purchased our city place last fall, we were informed by the owner that the four large cherry trees growing there had produced him one crop that yielded seventy dollars, and that one tree yielded twenty dollar's' worth of cherries. This seemed to me a very large story, but as he related it after the place had been purchased, I had no reason to disbelieve it. I have had the pleasure to test these four cherry trees. Three of them are Black Tartarian and the other Napoleon, a white cherry, very firm flesh; in great demand for canning and shipping. These trees are loaded down with beautiful cherries; making a rough calculation at the low price of four cents per pound, I should judge that ten dollars' worth of cherries per tree might have been sold from those trees; but aside from the market value of the fruit, these trees were a constant delight to the children and other members of the family for the shade which the brond leaves furnished, the beauty of the blossoms and the display of brilliant fruit as it ripened. I can heartily recommend the cherry tree to any home ground. It suceceds without cultivation, is long-lived, and in every way desirable. Cherry culture for market does not receive the atiention in the East which it shonld. It is clear that any one who has an acre or more of cherries can receive a very nice income from the fruit. It should be taken into consideration that it requires considerable help to pick the fruit. We pay one cent per pound and sell them for four and five rents per pound, but many get them picked for one-half cent per pound or less. One hundreel pounds is a day's work. (herries must not be permitted to get too ripe before picking, if it is designed to ship far. 


\section{GREAT CHERRY ORCHARD.}

Probably there is no better-known ranch, and certainly there are few larger, in the state of California, than that owned by the Meek estate, says the San Francisco Ware. It is situated a little way outside the city of Oakland, and it covers a huge tract of land between San Lorenzo and Haywards. It is spread over 3300 acres of some of the finest fruit-bearing country on the Pacific coast. A thousand acres of this extent is in fruit, for the most part cherries.

The ranch is owned and controlled by the two Meek brothers and their sisters, how skilfully may be known from the fact that, in spite of hard times and a depressed market, there has never been a year when it has not paid, and paid liberally. A full crop of cherries from this wonderful orchard will bring its owners anywhere from $\$ 30,000$ to $\$ 3 \tilde{0}, 000$.

During the cherry-picking season a little army of pickers toil from tree to tree, stripping the branches like a swarm of locusts.

The sight is picturesque, for the pickers come by families and live in the orchard, in a small village of tents. At the height of the season nearly 150 pickers are employed. They are of all ages and both sexes, as the work is of such a nature that it can be performed as well by women as by men-as well by a ten-year-old girl as by a grown man. The pickers are, of course, boarded at the expense of the ranch, and beside are paid from seventy-five cents to one dollar per day, so that a wife and two or three children can make as much money during the few reeks of the picking season as the head of the house can earn during the entire year.

After the picking, the cherries are taken over to the packing-house and handled at once. The riper cherries are sorted out and put upon local markets, while the more backward are shipped East. The force of packers can dispose of 420 boxes per day. Two thousand boxes go to the car-load and must be hurried to their destination as speedily as possible, for there is no fruit that loses its flavor quicker by overkeeping than the cherry. For the same reason the boxes must be rapidly marketed, for they will not keep many hours in the heat of an Eastern summer. There are plenty of difficulties in the way of getting the California cherry upon the dining table of the Eastern consumer, but, with ordinary care and a fair season, the prices obtainable are not bad. In Chicago a ten-pound box of California cherries can be made to bring a dollar, if properly handled, while in New York, though the Eastern local market comes into competition, the same quality will sometimes sell for twelve cents per pound. 


\section{INSECTS ON THE CHERRY.}

By Prof. J. M. Stedman, of Missouri.

There are not so many insects which prey upon the cherry as upon the apple. The New York weevil and the imbricated snout beetle feed on the young and tender bark and foliage and sometimes upon the buds hefore they open in the spring. We know little of the lifehistory of these insects and must fight them upon the tree itself. At a time when the trees are leaved out it is difficult to reach the twigs which are covered with the leaves, but it can be held somewhat in check by spraying with the arsenate of lead.

Tent-caterpillars of both species work on cherry trees, and can be fought as spoken of in the apple. The fall web-worm can be twisted out with a forked stick if you take it in time. The cherry borer is found only in a few localities. It is not general in the state. It is difficult to fight in a very successful way. Use the same wash that I recommended for apple borers.

Cherry leaves are eaten by a number of lepidopterous insects Spray with arsenate of lead in preference to Paris green, London purple, arsenate of lime, or soda.

To make arsenate of lead, use eleven ounces of acetate of lead and four ounces of white arsenic to fifty or seventy-five gallons of water. This formula is for any biting insects on the cherry. The leafcrumpler will damage the cherry more than the apple. The cankerworm also feeds upon the cherry. Give all of them the arsenate of lead.

The curculio is difficult to fight; much more so than in the case of the plum. It makes the wormy cherries. These do not drop from the tree like the plum, but hang on and ripen with the good cherries. It is often difficult to distinguish them from the good ones till you eat them. Cherry trees are usually too large to jar successfully. Spraying does not pay, rarely reaching fifty per cent. of them. Birds can keep these insects in check.

\section{A CURCULIO PREVENTIVE.}

Clear the ground under the trees of undergrowth of any nature, then stir the soil about one inch deep, and apply on top (in early spring, before any fruit is set, or, if soil will permit the working, before bloom falls) the following: One bushel of air-slaked lime, one bushel of wood ashes, two pounds of concentrated lye, two pounds of copperas, ten pounds of sulphur, one package of salt; mix with a hoe, and apply through an old sieve. Protect the hands while applying it, or they will suffer much.-Rural World. 


\section{DISEASES OF THE CHERRY.}

LEAF-SPOT. - The cherry suffers from a "shot-hole" disease similar to those which riddle the leaves of the peach and plum. Indeed, this identical fungus attacks the plum as well as cherry, though not so badly. Its botanical name is Septorin ceresina. This fungus appears on the leaves in early summer as dark brown or blackish circular spots, which soon fall away, leaving the holes. The fungus attacks only the leaves. In central Carolina it usually entirely defoliates the trees by August 1. The spores of the fungus live through the winter in the diseased leaves of the previous season.

Remedies: Gather up and burn all diseased leaves as soon as they fall. Spray in spring just before the buds start, with the copper sucrate mixture. Spray again when leaves are one-half grown, with the liver of sulphur solution. Repeat this in two or three weeks. Preventive treatment is necessary with this pest, and, therefore, the first two treatments must be given in time and with carefulness. It must be remembered that this disease attacks both plum and cherry, and may be communicated from one to the other.

Mildew of Cherry. - The cherry is attacked by two species of mildews, namely, Podosphara cerasi and $P$. tridactyla. They attack the leaves only, producing on one or both sides a white, powdery covering. something like the powdery mildew of the grape. The spores of the fungus pass the winter in the diseased leaves of the preceding season.

Remedies: Gather and burn all leaves as soon as they fall. Spray once before the buds burst, with the copper sucrate mixture. As soon as the leaves are half-grown, spray with the liver of sulphur solution. Repeat in two weeks. This will probably suffice.

\section{CURCULIO.}

From Bulletin No, 65, Utah Experiment Station.

This pest is very injurious to plums, cherries, peaches, and apricots. The mature insect is a dull gray, rough-backed beetle, about threesixteenths of an inch long. As soon as the tiny fruits are formed the? female beetle is on hand to "sting" them. "Stinging" consists of the female puncturing the skin, then depositing an egg in the puncture. and cutting a crescent-shaped slit at one side and beneath the egg. It is then in a little flap and will not be crushed by the development of the fruit. In about a week the egg hatches and the larva tunnels to the pit, where it feeds for from three to five weeks, and then escapes 
and enters the ground to a depth of a few inches. Here it transforms to the pupa stage, from which it changes to a mature insect in three or four weeks. The beetle spends the winter under any rubbish or under the rough bark of trees.

fiemely: The universal practice is to catch the beetles by jarring. There are several methods of doing this, the most ordinary of which is to spread a sheet or pieces of canvas on the ground beneath the tree and strike the limbs with a padded mallet. When disturbed the insects play "possum " and drop on the sheet, from which they are readily collected and destroyed.

A more improved method used in commercial orchards is a two-wheeled cart upon which is built a light frame in the position of the ribs of an inverted umbrella. Over this frame is spread a canvas, the center part of which is two or more feet lower than the edge. The canvas has an opening at the center, below which is fastened a zinc box about one foot in length, breadth, and depth. On the front side of the canvas is an opening wide enough to accommodate the trunk when the cart is pushed under the tree. A few jars with a padded mallet dislodge the beetles and they drop on the canvas, from which they are swept into the box below, after which they may be killed in whatever manner is most convenient. The jarring should be begun as soon as the petals fall and be continued as long as any insects are caught. It is best done in the morning while the insects are quiet; later in the day they become active and fly away when disturbed.

Spraying with poisons is also recommended, but with rarying results, by different experimenters. Paris green, London purple, or green arsenoid, one pound, with from three to five pounds of freshly slaked lime, in 250 gallons of water, should be applied first when the leaf buds are opening. The second application should be given as soon as the petals fall, and a third about ten days later. The poison may be combined with Bordeaux mixture at the rate of one pound to 250 gallons when the latter is used against the shot-hole fungus.

\section{CHERRY SLUG. (Eriocampa cerasi Peck.)}

The pear slug is exceedingly injurious to pear and cherry foliage, eating the upper side and tissue of the leaves. The remaining parts are practically destroyed and soon assume a brown and scorched appearance. The mature insect is a small saw-fly, which might be mistaken for an ordinary house-fly.

Remedy: In the early part of the season, before the fruit is half grown, green arsenoid, Paris green or London purple may be used, at the rate of one pound to 160 to 200 gallons of water, adding three pounds of lime. After this do not use the above poisons for fear of injuring the fruit for food, but instead apply fresh hellebore, one ounce to two gallons of water. Hellebore may be used any time during the season, even when the fruit is ripening. Spraying must be done often enough to hold the worms in check. 


\section{CURCULIO IN CHERRIES.}

By H. E. Sommers, State Entomologist, Ames, Iowa.

The "white worms" usually found in cherries are the larve of the plum curculio (Conotrachelus nenuphar), which seem to be quite as fond of cherries as of the plum. It does not cause the cherry to drop, however, as is usually the case with the plum, but the nearly full-grown larve are found in the ripe fruit when it is picked.

The only treatment is to destroy the beetles before they have laid their eggs in the young fruit. This treatment must be applied not

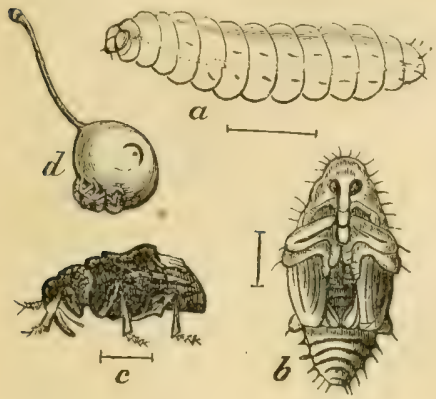

$a$, larva: $b$, pupa; $c$, adult; $c$, a plum showing puncture and crescent. only to the cherry but to the plum, and, to be entirely effective, to the peach, nectarine, and apricot, where these are grown. The tree must be sprayed at least three times, and four is better. The first before the flower-buds open, the second immediately after the blossoms have fallen, the third ten or twelve days later, and the fourth abont two weeks later still.

For the curculio alone the application may be, Paris green 1 pound, fresh lime 1 pound, water 200 gallons. As, however, cherries are subject to rot and leaf diseases, which may be largely prevented by the use of Bordeaux mixture, it is much better to apply the Paris green in conjunction with this fungicide. The combined mixture consists of copper sulphate 4 pounds, quicklime 4 pounds, Paris green 4 ounces, water (one barrel) 40 to 50 gallons.

Dissolve the copper sulphate (bluestone) by suspending it into a wooden or earthen ressel containing four or five or more gallons of water. Slake the lime in another vessel. If the lime, when slaked, is lumpy or granular, it should be strained through coarse sacking or a fine sieve. Pour the copper sulphate solution into a barrel, or it may be dissolved in this in the first place: half fill the barrel with water, add the slaked lime; fill the barrel with water, and stir thoroughly; it is then ready for use.

Stock solutions of dissolved copper sulphate and of lime may be prepared and kept in separate covered barrels throughout the spraying season. The quantities of bluestone, lime and water should be carefully noted. 


\section{ANOTHER CURCULIO CATCHER.}

The curculio attacking quinces, plums, peaches and a few other fruits is but little affected by spraying mixtures of any kind. The mouth-parts of the insect are elongated in the form of a beak, and when the curculio damages the fruit, very little if any of the poisonous substances which may have been applied in the spraying solution is taken into the system. The most effective means of combating the insect, therefore, is to take advantage of its habit of dropping to the ground when alarmed. If a cloth is sprearl under the tree and the limbs struck with some kind of a pole, the insects will drop at once onto the sheet and can be collected and destroyed.

Placing the sheet about the trees is a slow process. Consequently, the Cornell station has suggested a device. It consists of an arrangement built on the plan of a double-wheeled wheelbarrow with much elongated axle. On this are arranged a number of projecting arms radiating from a point midway between the two wheels. A canvas or any kind of cloth is attached to these arms, with an opening on the far side large enough to ądmit the trunk of the tree. This is very inexpensive and easily built.

The time to begin jarring is still a question, but as the curculio are usually more active in the early morning, possibly the work had best be done then. These beetles begin operations as early as May, arid it will not do to delay jarring them much after they appear. Some years they will not appear until the latter part of July. Those who practice this method successfully jar the trees every day until the numbers are so small that they do not affect the fruit seriously. In one orchard, noted by the Cornell station in 1897, 200 curculio were jarred from seven trees, and it is not uncommon to get as high as fifty from one tree at a single jarring. This process involves considerable labor and expense, but it costs only about fifteen to twenty cents per tree for one senson. After the insects are captured they can be destroyed by the most convenient method. Some put them in kerosene or boiling water, while others have a charcoal stove built for the purpose, in which everything that falls on the sheet is burned.Orange Judd Farmer. 


\section{INSECTS AND DISEASES OH CHERRILS.}

Insects and diseases are not serious upon the sour cherries. The curculio does not often attack the mid-season and late varieties-such as Montmorency and Morello - seriously, particularly if the number of trees is somewhat large. In occasional years, however, this insect becomes a sourge. The grower must watch his fruits closely after the blossoms fall, and if the curculio injuries become alarming, he must catch the insects by jarring them onto sheets. There are those who declare that they attract the curculio away from the cherries by planting plum trees in the cherry orchard, but I greatly doubt the efficiency of this procedure. A complete account of the curculio may be expected in a forthcoming bulletin.

The leaf-blight, or shot-hole fungus (cylindrosporium pudi or septoria cerasina, the same which attacks the plum), is often a serious enemy, particularly upon English Morello. The leaves begin to assume a spotted character, generally before the fruit is picked; they soon turn yellow and they fall prematurely. Thorough spraying with Bordeanx mixture is as efficient in holding the leaves on the cherry as it is on the plum. The trees should generally be sprayed twice between the falling of the blossoms and the coloring of the fruit. If the cherries are more than half grown when the last spray is applied, the ammoniacal carbonate of copper may be used in place of the Bordeaux, to avoid discoloring the fruit; but it is doubtful if the last spray should be delayed until this time. It may be necessary to spray once after the fruit is off.

CHERRY APHIS. (Myzus cercesi.)

This is a black species, and is sometimes found on the cherry tree in enormous numbers, usually on the leaves only, but also attacking the tender twigs. They hatch from eggs deposited the previous autumn on the twigs, and for a few weeks in May and June increase very rapidly. Usually their numerous enemies lessen their numbers so greatly that they may nearly or entirely disappear after three or four weeks. In August they appear again, but usually not in such numbers as earlier in the season. As yet this species does not seem to be abundant in the state, but we have received specimens from nearly every fruit-growing section.

\section{CHERRY APHIS.}

This little insect is one family of a large species, commonly known as plant-lice, but are nearly black in color. They appear early in the spring and begin sucking the juice from the expanding buds. They multiply very rapidly, and as growth takes place move to the new shoots and leaves, where they collect in large numbers, especially on 
the under side of the leares, causing them to curl up so as to cover the lice, and thus making it difficult to hit them with a spray after they have become well established. Since these insects suck their food they cannot be poisoned, but must be killed by contact of the insecticide with their bodies.

Remedy. - In fighting these insects close watch should be kept for their first appearance, so that they may be sprayed at once and not allowed to become established. The treatment should be repeated as circumstances require. Kerosene emulsion diluted from twelve to fifteen times is commonly recommended for plant-lice. If the leares are curled so that the spray cannot reach the inset, dip the infested twigs in whale-oil soap and tobacco tea, or in kerosene emulsion prepared as follows: Dissolve one-half pound of either common salt or whale-oil soap in one gallon of soft water. Heat the mixture, and, when boiling hot, remove it from near the fire and add it to two gallons of kerosene. The whole is now thoroughly mixed by pumping continuously through a small force-pump for from five to fifteen minutes. Mix until the ingredients form a creamy mass that becomes thick when cool and from which the oil does not separate. When using on foliage dilute with from ten to fifteen parts of water; when used as a winter treatment, it may be applied as strong as one part of the mixture to four parts of water. In diluting the stock emulsion, first use three or four parts of boiling water, and then dilute to the required strength. Soak off with paper any free oil that appears on the surface, as it will work injury if applied to the plant. This emulsion is used to kill insects that have sucking mouth-parts; it is not a poison, but kills by contact. The emulsion causes rubber valves to swell and clog the tubes in which they work. Where rubber balls are used for valves they ehould be replaced with glass or marble balls when using the pumps for kerosene emulsion. The misture may be poured into shallow pans, and the twigs bent over and dipped into it.

\section{BLACK-KNOT OF THE CHERRY。 (Plowrightia morbosa Schw.)}

The black-knot of the cherry is distinctly an American disease, and is recognized at a glance by the rough, wart-like swellings which cover the branches and sometimes even appear on the trunks of the trees.

Where the fungus is not checked whole orchards soon become affected, and are a serious menace to every healthy tree in the vicinity. The fungus was described about seventy years ago by the mycologist Schweinitz, who thought, however, as many do still, that the trouble was due to insects, from the fact that there is often found the larva of insects imbedded in the galls. But since the very careful and systematic study of the black-knot by Dr. W. G. Farlow in 1886, there is no reason to doubt that it is caused by a parasitic fungus, the spores of which, after ripening, become detached from the knots and are carried by the wind or by insects to healthy trees, where in some manner they penetrate to the cambium layer, where they take root and grow, producing galls similar to the one from which they became detached.

Preventives and Remedies.-As the galls are found on the native cherry growing wild in fence-corners and abandoned places, they should be sought out 
and burned. When found on cultivated trees, the diseased portions should be at once cut out to at least three inches below the knot and burned, and the wound treated with a strong ten-per-cent. solution of copper sulphate. If the work is done while the trees are dormant, they can be sprayed with the same solution, which will be likely to destroy any spores resting on the trees awaiting a favorable time for development. Where the knots are cut ofi, after treating the wound with iron sulphate, cover with a linseed-oil paint.

\section{BROINN ROT.}

The cherry, like the plum, only more so, suffer's from brown rot, produced by the fungus Momilia fimatigema. It must be treated as directed in case of the peach.

\section{CHERRY APHIDE.}

The worst insect enemy of the cherry in the Carolinas is the cherry aphicle or louse, Myzus rerrsi. This pest resembles the aphides of the apple, peach and plum, and must be treated in the same way. The leaves only are attacked.

\section{THE JUNE BEETLE.}

The cherry is also attacked by the . Tume beetle, already treated of, and which must be combated as prescribed for the peach.

\section{THE DOG-DAY CICADA.}

The dog-day cicada, ('icurla tubicen, an annual species, resembling somewhat the seventeen-year periodical cicada, is sometimes troublesome to the cherry by puncturing the small twigs and laying its eggs therein. These eggs hatch and the larvie enter the ground, but complete their development in one year.

liemedies: Gather and burn all twigs slowing the slits or nests of this insect.

\section{THE FRUIT-TREE BARK-BEETLE.}

From Kansas Experiment Station Bulletin.

Of the insects that have been introduced into this state during the past few years, none seem to be more destructive to stone-fruit trees than the fruit-tree bark-beetle. or shot-borer, as it is sometimes called, from its peculiar habit of riddling the bark of the trees with numerous small holes. The insect has been found in Riley, Bourbon and Allen counties, and without doubt is present in a large number of the other counties of the state. In Allen county it was very numerous, particularly in an orchard of cherry trees which were suffering badly from the cherry scale (Aspidiotus forbesi).

The presence of the pest will probably be first shown by the wilting and falling of the leaves at an unseasonable time. A close examination of the tree infested with the insect will reveal numerous small holes in the bark, from which in the case of the stone-fruit trees, such 
as the plum, peach, cherry, etc., there is a considerable exudation of gum. To show how the insect may riddle a tree, a piece of bark less than an inch square, taken from an infested cherry tree, contained nineteen perforations about the size of a pin-head.

The insect that is the cause of the mischief is a small beetle about one-tenth of an inch in length by about one-third as wide. It is black in color, with the exception of the wing-covers and the lower part of the legs, which are reddish.

With the beginning of spring the beetles appear, and commence to bore small round holes through the bark to the sap-wood, where they make a central burrow or brood-chamber, on each side of which little pockets are made, in which eggs are deposited. As the larvæ hatch from the eggs they commence to make burrows away from and at right angles to the brood-chamber, which become larger as the larvæe develop in size.

The larva is a small grub about one-tenth of an inch in length. It is footless and white, with the exception of the hearl, which is brownish.

When the larva has attained its full growth it makes a slightly enlurged chamber, in which it pupates. Upon becoming an adult, the beetle makes it way out through small holes in the bark, and escapes. It takes about a month for the insect to go through its various stages, so that during the summer there may be several broods. Many of the beetles upon emerging will return and renew their attack upon the tree, thus increasing the damage that has already been done. In time the tree becomes completely girdled by the numerous channels, and dies.

Strong and vigorous fruit-trees may resist for a time the attacks of the beetles throngh the exudation of the gum, which seems to be obnoxions to both the beetles and the larvæ. But if the attacks are continued for a length of time, the tree may be so weakened that the flow of sap will not be strong enough to repel. In such a case it is not long before the fate of the tree is sealea, unless vigorous and prompt measures are taken for its protection.

To prevent loss from this insect, the tree should be kept in a healthy condition. The stronger the tree the better it can resist attack. Trees that are diseased or are suffering from the attacks of scales or other insects seem most subject to attack.

It is a good practice to remove and destroy all dead wood in the orchard, as it furnishes excellent breeding-places for insects and is a source of danger to surrounding trees.

Badly infested trees should be cut and destroyed. In the early spring the trunks of trees liable to attack should be coated with an alkaline wash, consisting of soft soap reduced to the consistency of 
paint by adding washing soda dissolved in water. Enough carbolic acid should be added to give a strong repellent odor to the mixture. Apply the wash with a stiff brush. Several applications should be made during the spring and summer.

\section{MEDICINAL PR()PERTIES OF THE CHERRY.}

Cherries are an absolute cure for rheumatism. I have never known a person to suffer from rheumatism who ate freely of cherrie's, and I know of hundreds who have been relieved of attacks by eating them. I have often had cherries ordered two and three months before the season for them opened hereabouts, and to supply the orders have had to send to Cuba and California for them. The ordinary cherry contains an acid which relieves if it does not effectually cure. Of course, it may all be in the season, and that rheumatism would disappear anyhow, but it is safe to say that there is no rheumatism during the cherry season. I don't know of anything healthier, though even the besttasting, thoroughly ripe and perfect cherries start up very fine cases of cholic and cholera morbus, which are very annoying. The colored people of the South think, and it may be that the same belief exists clsewhere and among others as well, that all the cramp or colic is taken out of the cherry by eating it, swallowing stone and all. That unquestionably was the practice once, but in recent years fears of appendicitis may have changed it somewhat, though for the life of me I cannot understand why it is so dangerous now to swallow apple seed, grape seed, or cherry-stones, when in old-fashioned times it was the rule to do so rather than the exception.

\section{SOME STANDARD RECIPES.}

Canned Cherries. Allow three-quarters of a pound of sugar to every pound of cherries. Put into a porcelain-lined kettle; cook sufficient to fill one jar only at a time; bring slowly to boiling-point: simmer until the cherries are soft, without being broken, skim, and can. All large cherries may be canned in the same manner, first pricking the skins to provent cracking. "Canning and Preserving," by Mrs. Rorer.)

Another: Wash and put whole in a syrup made in the proportion of a pint of water and a pound of sugar to erery two pounds of fruit; boil for eight minutes; can and seal immediately. (Buckeye Cookery.)

Cherry Chalotte. Stone a quart of ripe cherries and mix them with a pound of brown sugar. Cut slices of bread and butter, and lay them around the sides and in the bottom of a large, deep dish. Pour in the fruit boiling hot, cover the bowl, and set it away to cool gradually. When quite cold, serve with sweet cream. This is very nice in hot weather. (Skilful Housewife's Book.) 
Cherry Compote.-Simmer five ounces of sugar with a half-pint of water for ten minutes; throw into the syrup a pound of cherries weighed after they are stalked, and let them stew gently for twonty minutes; it is a great improvement to stone them, but a larger quantity will then be required for a dish.-(Mrs. Hale.)

Cherry Compote of Morellos. Boil together for fifteen minutes fire ounces of sugar with one-half pint of water; add one and one-fourth pounds of ripe Morello cherries, and simmer very gently from five to seven minutes. This is a delicious compote. (Mrs. Hale.)

Dried Cherries. Fruits for drying should be perfect and quite ripe. Cherries should be stoned before drying. Spread them in a single layer on boards and stand in the hot sun to dry graduually until they turn leather-colored, bringing in always before sunset, and never put them out in cloudy or damp weather. A piece of mosquito-netting will prevent the flies from reaching them. When dry, put in paper sacks and hang in a dark, dry, cool place. All fruits may be dried in the oven, providing the oven is not sufficiently hot to scorch or seald them. The fruit is dried more quickly, and you escape the danger of its being stung by insects. (Mrs. Rorer, in "Canning and Preserving.")

Dried Cherries.-Cherries are dried as follows: Put in jars first a layer of fruit, then a layer of sugar, in the proportion of a half a pound of sugar to a pound of fruit; let stand over night; place them to boil, skimming off all scum: let boil ten or fifteen minutes, skim out and spread on dishes to dry in the sun or by the fire, turning frequently until dry; then place on pans in the oren, stirring with the hand often until the heat is too great to bear. They may then be placed in jars with sugar or put away in paper sacks, or stone crocks with a cloth tied over the top, and are an excellent substitute for raisins in pudding or mince-pies.

The secret of keeping dried fruit is to exclude the light, and to keep in a dry and cool place. Paper sacks, or a barrel or box lined with paper, are secure against moths. Reheating fruit makes it dark in color and impairs the flavor. Always fill a fruit-can and keep for present use, to avoid opening the large jars often. (Buckeye Cookery.)

Cherry Man.--Stone four pounds of cherries and put them in a preservingpan with two pounds of fine white sugar and a pint of red-currant juice: their own juice will do. Boil the whole together rather fast, until it stiffens, and then put it into pots or jars for use. (Mrs. Hale.)

Cherry Jelly. Put the cherries into a stone jar, stand it in a kettle of cold water, cover the top of the jar, and heat slowly until the cherries are soft. Now put a small quantity at a time in your jelly-bag, and squeeze out all the juice. Measure the juice, and to each pint allow one pound of granulated sugar. Turn the juice into a porcelain-lined kettle and stand over a brisk fire. Put the sugar into earthen dishes and stand in the oven to heat. Boil the juice rapidly and continuously for twenty minutes, then turn in the sugar hastily, stirring all the while until the sugar is dissolved. Dip your tumblers quickly in to hot water, watch the liquid carefully, and as soon as it comes again to a boil, take it from the fire and fill the tumblers. If the fruit is overripe your jelly will never be firm, no matter how long you boil it. Follow these directions carefully and you will nover fail. (Mrs. Rorer, in "Canning and Preserving.") 
Cherries-Pickled. Use the common or Morello cherries; pick off the stems, see that they are perfect, and lay them in a glass or earthen jar, with sufficient cold vinegar to cover them, and keep them in a cool place. They need no spices, as they retain their own flavor. (Skilful Houservife.)

Cherry Pie. Stone your cherries, that you may be sure they are free from worms; lay your paste in a deep dish, and add a good quantity of fruit; fill the dish with molasses, with a handful of flour sprinkled over, then a nice paste on top, and bake more than half an hour. If sugar is used, you will need water and flour. This makes the grary rery rich and the pie delightful. (Skilful Housewife.)

Cherry Pie.- Line a pie- tin with rich paste; nearly fill with carefully seeded fruit, sweeten to taste, and sprinkle evenly with a teaspoon of corn-starch or a tablespoon of flour; add a tablespoon of butter cut in to small bits and scattered over the top: wet edge of crust, put on upper crust and press the edges closely together, taking care to provide holes in the center for the escape of air. (Buckeye Cookery.)

Cherry Preserves. Choose sour ones-the Early Richmond is good-seed all very carefully, allow an amount of sugar equal to the fruit; take half the sugar, sprinkle over the fruit, let stand about an hour, pour into a preserving kettle, boil slowly ten minutes, skim out the cherries, add balance of sugar, boil, skim, and pour over the cherries; the next day drain off the syrup, boil, skim if necessary, add the cherries, boil twenty minutes, and seal up in small jars. (Mrs. J. M. Southard, in "Buckeye Cookery.")

Spiced Cherries. Seven pounds of cherries, four pounds of sugar, one pint of vinegar, half ounce of ginger root, one teaspoonful of ground cloves, two teaspoonfuls of allspice, two teaspoonfuls of cinnamon, half teaspoonful of ground mace. Do not remove the stones. Put the vinegar and sugar on to boil. Mix the spices and divide them into four parts. Put each into a small square of muslin, tie tightly and throw into the sugar and vinegar. When this mixture is hot, add the cherries; bring to boiling-point, take from the fire, and turn carefully into a stone jar. Stand in a cool place over night. Next day drain all the liquor from the cherries into a porcelain-lined kettle, stand over a moderate fire, and, when boiling hot, pour back in to the jar over the cherries. Next day drain and heat again as before; this do for nine consecutive days; the last time boi the liquor down until there is just enough to cover the fruit. Add the fruit to it, bring to a boil, and put in jars or tumblers for keeping. (Mrs. Rorer, in "Canning and Preserving.")

Cherry Syrup. Mash the cherries and stand aside in a warm place for four days; cover to keep out dust and insects; then turn into a jelly-bag and let Arip slowly. If you wish it very clear, filter through filtering paper. Measure the juice, and to every pint allow two pounds of granulated sugar. Mix the juice and sugar together until only a small portion settles to the bottom; then pour it into a double boiler, place over the fire, and the heat of the water as it boils around will dissolve the sugar. When this has been thoroughly effected, take it from the fire and stand aside to cool. When cool, put into small bottles, fill them to the top, cork tightly, seal, and keep in a dark, cool, dry place. Be very careful that you use only porcelain or granite articles in the making of syrups, as the acids of the fruits will act upon metal and change the bright-red color to a purple. Use a wooden spoon in stirring. Strong heat or boiling also destroys the color and flavor of syrups. ([Mrs. Rorer, in "Canning and Preserving.") 


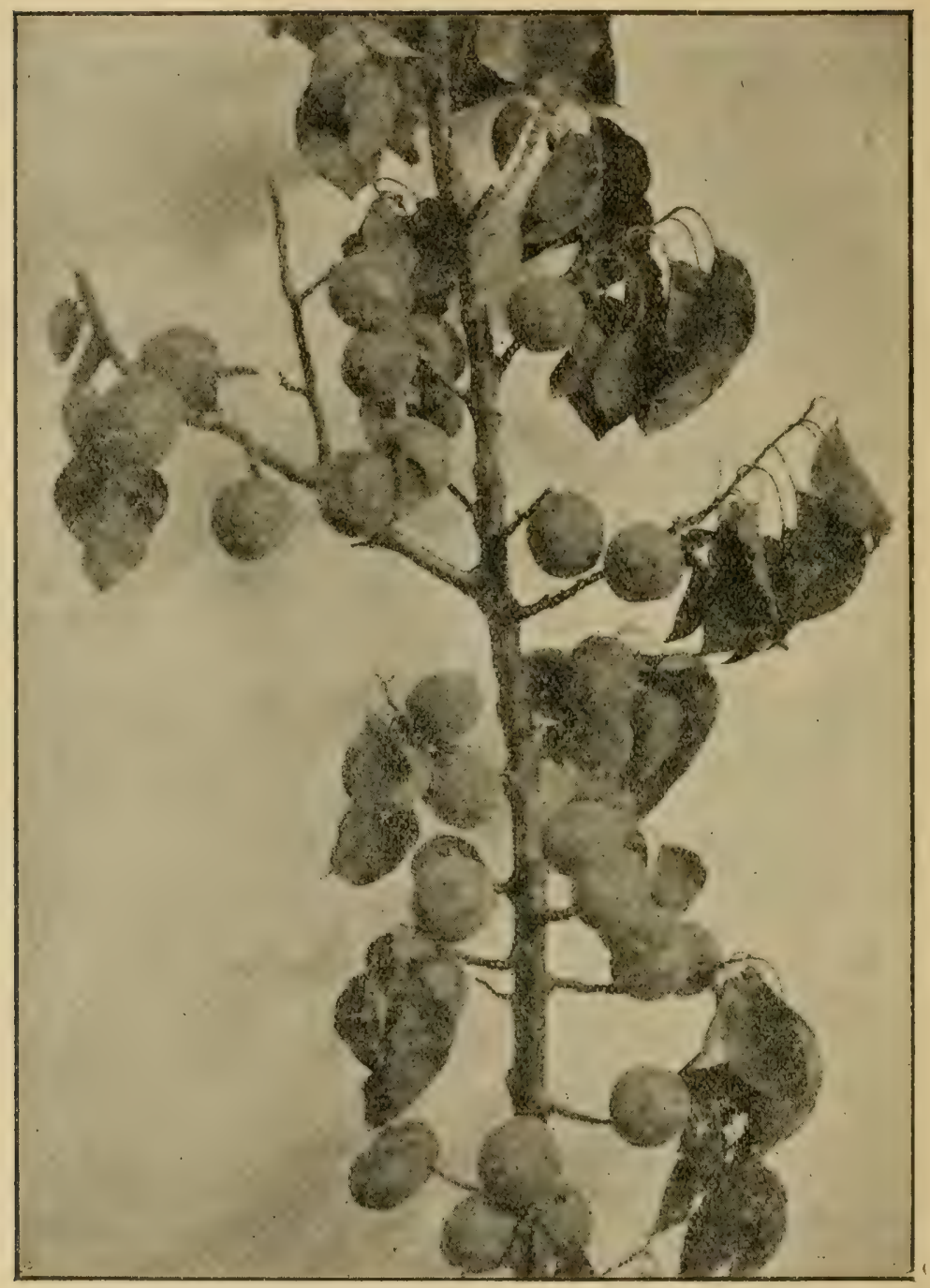

SUPERB APRICOT.

Originated with A. H. Griesa, Lawrence, Kan. 


\section{APRICOTS.}

It is hoped that the reader may be favorably impressed with the usefulness and value of the apricot by what is recorded here. The thirty-five Kansas growers who are quoted are scattered over our state, and while all fear late spring frosts yet all declare it a nice fruit for family use and the surplus is always salable at good prices. California has over three million trees, and California apricots are known the world over, either fresh, canned, or evaporated. They form a handsome tree for shade, being very dense, and the acid of the fruit is surely good for the human system in hot weather. Why should Kansans depend on California for apricots? I have eaten as fine apricots in Marion county, Kansas, as I ever saw come from California. If I did not know that Kansans are honest from living thirty years among them, I could readily believe that the best apricots, wrapped carefully and boxed nicely, were grown and packed within the borders of our state. Apricot trees are not costly, can be obtained at any nursery: should be set about eighteen feet apart, with same care as peaches, being trimmed to a stick. As they grow, head them back annually. Cultivate well for six or eight years, until well grown. They do best on strong land. Moorpark and Early Golden are probably best, unless some Kansas seedling ( Superb, Home, Remer or others) may be more hardy. Many small plantings should be tried in our state. If our horticulturists say they will grow apricots, they will.-SECRETARY.

\section{WHAT AN APRICOT IS.}

Century Iictionary definition: A roundish, pubescent, orangecolored fruit, of a rich aromatic flavor, the produce of a tree of the plum kind, Prunus armeniaca, natural order Rosace.e. Its specific name is due to the belief that it is a native of Armenia, but it is now supposed to be of Chinese origin. It grows wild in the Himalayas and northwestern provinces of India, where its fruit is gathered in great quantities. It was introduced into England in 1524 , by the gardener of Henry VIII. The tree rises to the height of from fifteen to twenty and even thirty feet, and its flowers appear before its leaves. 
In cultivation it is often propagated by budding upon plum stocks. There are a considerable number of varieties, some of them with sweet kernels which may be eaten like almonds. The wild apricot of the West Indies is the Mammer armeniaca; that of Guiana, the Cuuroupita guianensis.

Standard Dictionary definition: A fruit allied to the plum, of an orange color, oval shape, and delicious taste; also, the tree (Prunus armeniaca) which bears this fruit. By cultivation it has been introduced throughout the temperate zone.

\section{APRICOTS.}

(From Downing's "Fruit and Fruit-trees of America."

Armeniaca vulgarics, of botanists; Alricoticr, of the French; Aprikosenbaum, of the German; Lbercoco, of the Italian; Albaricoque, of the Spanish.

The apricot is one of the most beautiful of stone-fruit trees, easily known by its glossy, heart-shaped foliage, large white blossoms, and smooth-skinned golden or ruddy fruit. In the fruit-garden it a highly attractive object in early spring, as its charming flowers are the first to expand. It forms a fine spreading tree of about twenty feet in height, and is hardy enough to bear as an open standard south of the forty-second degree of latitude in this country. The native countries of this tree are Armenia, Arabia, and the higher regions of central Asia. It is largely cultivated in China and Japan; and, indeed, according to the accounts of Grosier, the mountains west of Pekin are covered with a natural growth of apricots. The names by which it is known in various European countries all seem to be corruptions of the original Arabic term Berkoche.

Uses.-A very handsome and delicious dessert fruit, only inferior to the peach, ripening about midsummer, after cherries and before plums, at a season when it is peculiarly acceptable. For preserving in sugar or [camning], for jellies or pastries, it is highly esteemed, and, where it is abundant, it is also dried for winter use. In some parts of Germany, the free-bearing sorts - the Turkey, Orange, and Breda - are largely cultivated for this purpose.

Cultivation.-This tree is almost always budded on the plum stock (on which in July it takes readily), as it is found more hardy and durable than upon its own roots. Many nurserymen bud the apricot on the peach, but the trees so produced are very inferior in quality, short-lived, more liable to disease, and the fruit of a second-rate flavor. Budded on the plum they are well adapted to strong soils, in which they always hold their fruit better than in high, sandy soils. Apricots [trees] generally grow very thrifty, and soon make fine heads, and pro- 
duce an abundance of blossoms and young fruit; but the crop of the latter frequently falls off when half grown, from being stung by the plum-weevil or curculio, to which the smooth skin of this fruit seems highly attractive. To remedy this, the same course must be pursued as is directed for the plum. Seedling apricots are usually more hardy and productive here than the finer grafted sorts. This is a favorite tree for training on walls or espaliers, and, in town gardens especially, we often see it trained against the side of brick houses, and yielding most abundantly. It bears its fruit in the same way as the peach, and requires the same management. As the apricot, howerer, expands its blossoms very early, it should not be placed on an east wall, or in a situation where it is too much exposed to the full morning sum.

Diseases.- When budded on the plum this tree is but little liable to diseases, and may be considered a hardy fruit-tree. In order to render it fruitful, and keep it for a long time in a productive state, we cannot too strongly urge the advantages of the shortening-in system of pruning recommended for the peach.

Downing describes forty-four varieties.

\section{THE APRICOT.}

From Thomas's "American Fruit Culturist."

It is remarkable that a fruit of such excellence as the apricot, that ripens from one to two months before the best early peaches, should be so little known. In its natural character it is more nearly allied to the plum than the peach, resembling the former in its broad leaf and the smooth stone of its fruit, but downy like the peach, and partaking largely of its flavor and excellence. The apricot is budded on seedling apricots, and on peach and plum stocks. Plum stocks are preferred, and are more especially adapted to heavy soils; on light soils the hard-shelled almond and the wild plum have proved excellent.

The soil should be deep and dry. Young trees have frequently perished from a wet subsoil, even where the surface is not unusually moist. On suitable soils, the tree is as hardy as most early peaches, but its greatest drawback is that its blossoms open so early and the young fruit is so tender that they are often destroyed by frost. The trees have been commonly planted in the warmest situations, as on the warm side of buildings or other sheltered site, facing the hot sun, where they have blossomed early, and, as a consequence, the crop has not unfrequently been destroyed by vernal frosts. Hence, a northern or more exposed aspect would be far preferable. If trained on a build- 
ing, the eastern side should be especially avoided, as a hot morning sun upon frosted buds would be nearly certain destruction.

The liability to the attacks of the curculio, and the very common destruction of the whole crop by this insect, have contributed to the general conclusion that the apricot is not suited to our northern climate. Several cultivators, as far north as forty-three degrees of latitude, by a systematic destruction of this insect, and by selecting a dry subsoil, are said to obtain heavy crops of this delicious midsummer fruit. More recently varieties from southern Russia have been introduced, which, so far as hardiness and vigorous, thrifty growth are concerned, appear to have advantages over the older kinds in cultivation. But thus far, in producing satisfactory crops of fruit for market purposes, apricots east of the Rocky mountains, neither North nor South, have been very successful. By careful management, of which it is surely worthy, sufficient for family use may be obtained wherever the fruit will grow, but that apricots may be expected to be about as productive as the peach, as one eminent authority has recently stated, unless indeed in a few favored localities, is hardly probable.

Thomas describes twenty-nine varieties.

\section{APRICOTS.}

By L. H. Bailey, in "Cyclopedia of American Horticulture."

The apricot is a fruit somewhat intermediate between the peach and the plum. The tree is a round-headed, spreading grower, with dark, somewhat peach-like bark, and very broad, or almost circular, leaves. The fruit, which generally ripens in advance of both the peach and plum, is peach-like in shape and color, with a smoother skin, rich, yellow flesh, and large, flat, smooth stone. The flesh is commonly less juicy than that of the peach, and, as a rule, perhaps, of higher quality. The apricots are of three species, all probably native of China or Japan. The common apricot of Europe and America is Pmuns americana; fruit variable, but smooth at maturity; red or yellow; the sweet and firm flesh free, or very nearly so, from the large, smooth, flat stone; tree with a round, spreading top, and a reddish, cherry-like or peach-like bark; leaves ovate or round ovate, with a short point and sometimes a heart-shaped base, thin and bright green, smooth or very nearly so below, as are the glandbearing stalks; the margins rather obtusely and mostly finely serrate; flowers pink white and borne singly, sessile or very nearly so, preceding the leaves.

The Russian apricot is a hardy but smaller-fruited race of the spe- 
cies. The Japanese apricot, in Japan grown for flowers rather than for fruit, is Prunus mume; fruit small, yellowish or greenish, the flesh rather hard and dry, and adhering tightly to the pitted stone; tree like the common apricot, but with a grayer or greener bark and duller foliage; leaves grayish green, generally narrower, and long pointed, more or less hairy along the veins below and on the shorter, mostly glandless stalk, thick in texture and prominently netted beneath; flowers fragrant, borne singly or in twos, and sessile (without stalks). Only recently introduced into this country, chiefly under the name of Bungoume plum.

The third species is the purple or black apricot, Prum drsyearpa, which is little cultivated; fruit globular and somewhat plum-like, with a distinct stem, pubescent or fuzzy even at maturity, dull dark purple, the sourish, soft flesh clinging to the plura-like fuzzy stone; tree roundheaded, with much the habit of the common apricots, with leaves ovate and more or less tapering at both enrls, thin, dull green, on slender and pubescent, mostly glandless stalks, finely appressed serrate, and hairy on the veins below; flowers large and plum-like, blush, solitary or in twos, on pubescent stalks half-inch or more long, and appearing in advance of the leaves. The apricot is as hardy as the peach, and it thrives in the same localities and under the same general cultivation and treatment, but demands rather strong soil. It is grown commercially in New York and other Eastern states.

There are three chief reasons why the apricot has remained in comparative obscurity in the East: Ignorance of the fruit; loss of crop by spring frosts, because of the very early season of blooming of the apricot; the fondness of the curculio for the fruit. To these may be added the fact that we have not yet arrived at an understanding of the best stocks upon which to bud the apricot; but this difficulty may be expected to disappear as soon as greater attention is given to the fruit and our nurserymen begin to propagate it extensively. Aside from the above difficulties, there are probably no reasons why apricots should not be grown in the East as easily as plums or peaches. The varieties of apricots which are chiefly prized in the Eastern states are Harris, Early Noorpark and St. Ambroise for early: Turkish or Roman, Montgamet, Royal and Mooryark for mid-season and late. Of the Russian race, the best known are Alexander, Gibb, Budd, Alexis, Nicholas, and Catherine. The ideal soil for the apricot seems to be one which is deep and dry, and of a loamy or gravelly character. The rolling loamy lands which are well adapted to apples seem to be well suited to the apricot, if the exposure and location are right. The apricot seems to be particularly impatient of wet feet, and many of the failures are due to retentive subsoils. 
Particular attention should be given to the location and exposure of the apricot orchard. In the East, the best results are obtained if the plantation stands upon elevated land near a large body of water, for there the spring frosts are not so serious as elsewhere. Generally it somewhat backward exposure, if it can be obtained, is desirable, in order to retard blooming. Apricots will be sure to fail in frosty localities. The apricot should always be given clean culture. For the first two or three years some hoed crop may be grown between the trees, but after that the trees should be allowed the entire land, particularly if set less than twenty feet apart. Cultivation should be stopped late in summer or early in the fall, in order to allow the wood to mature thoroughly.

The trees are pruned in essentially the same way as plums. The fruit-buds are borne both upon spurs, and also on the wood of the last season's growth, on either side of the leaf-bud. Each bud contains a single naked flower. As the fruit begins to swell, the ealyx ring is forced off over the top; and the injury from curculio may then be expected. When grown under the best conditions, the apricot may be considered to be nearly or quite as productive as the peach. Like other fruit-trees, it bears in alternate years, unless the crops are very heavily thinned; but it can never be recommended for general or indiscriminate planting. Only the best fruit-growers can succeed with it.

Apricots are to be considered as a dessert or fancy fruit, and therefore should be neatly packed, in sinall and tasty packages. The most sorious enemy of the apricot is the curculio-the same insect which attacks the plum and peach. It seems to have a particular fondness for the apricot, and, as the fruit sets very early, the crop may be expected to be destroyed unless the most vigilant means are employed of fighting the insect. Spraying with arsenical poison is uncertain. The insect must be canght by jarring the trees, in the same manner as on plums and peaches, but the work must be even more thoroughly done than upon those fruits. The jarring should begin as soon as the blossoms fall, and continue as long as the insects are numerous enough to do serious damage. It will usually be necessary to catch the insects for three to six weeks, two or three times a week, or perhaps even every day. The work must be done early in the morning, while the curculio is indisposed to fly. The operation consists in knocking the insects from the tree by a quick jar or shake, catching them upon a white sheet or in a canvas hopper. The catcher commonly used in western New York is a strong cloth hopper mounted upon a wheelbarrow-like frame, and running upon two wheels. The hopper converges into a tin box, into which the curculios roll as they 
fall upon the sheet. One man wheels the device by wheelbarrow-like handles under the tree, then drops the handles and jars the tree; or sometimes two men go with a machine, one wheeling it and the other jarring the trees. This device is used extensively by practical fruitgrowers for catching the curculio on the various stone fruits.

It is not yet certain what are the best stocks for apricots in the East, in commercial orchards. It is probable that no one stock is best under all circumstances.

The apricot root itself seems to be impatient of our cold and wet soils, which are drenched by the drainage of winter. It needs a very deep and rich soil, but it is doubtful if it is safe for the East. The common plum (not Myrobalan) is an excellent stock for plum soils, and the apricot does well either nursery budded or top-worked upon it. Peach is probably the commonest stock, and, for peach suils, it is probably the best that can be used. If the apricot thrives upon various stocks, it is thereby adapted to many soils. The apricot is often trained on walls, where the fruit reaches the highest perfection. Care should be taken that the wall does not face to the west or the south, or the early forced flowers may be caught by frost. An overhanging cornice will aid greatly in protecting from frost.

\section{THE APRICOT IN CALIFORNIA.}

By EDWARD J. WiCKSON.

The apricot is one of the leading commercial fruits of California. It was introduced by the mission fathers, for Vancouver found it at the Santa Clara mission in 1792. However, there is no relation between this early introduction and the expansion which quickly followed the American occupation, because the mission fathers had only seedling fruits, while the early American planters, shortly before the gold discovery, introduced the best French and English varieties, and were delighted to find that these sorts, usually given some protection in the old world, grew with surprising thrift of tree and size of fruit in valley situations in California in the open air. Upon these facts the apricot rose to wide popularity. The acreage has steadily increased during the last fifty years, and with particularly swift rate during the last twenty years, until the number of trees at the present date (1899) is about three millions, occupying upwards of 40,000 acres of land. This notable increase, and the present prospect of much greater extension, is based upon the demand which has arisen for the fruit in its fresh, canned, dried and crystallized forms in all the regions of the United States, in England, and on the continent, where, by reason of its superior size and acceptable manner of 
curing, it has achieved notable popularity. The year 1897 was the greatest thus far in amount of dried product realized, viz., 30,000,000 pounds. The year 1895 was greatest in amount of canned product, which reached upwards of 360,000 cases, each containing two dozen two-and-one-half-pound cans. The shipment of fresh apricots out of California during the summer of 1897 was 177 car-loads.

The chief part of the apricot crop of California is grown in the interior valleys. In the low places in these valleys, however, the fruit is apt to be injured and sometimes almost wholly destroyed by spring frosts, although the trees make excellent growth. In foot-hill situations adjacent to these valleys there is also serious danger of frost above an elevation of about 1500 feet above sea-level, and the tree is rarely planted for commercial purposes. In southern California the apricot succeeds both in the coast and interior valleys. But along the coast northward, excepting the very important producing regions of the Alameda and Santa Clara valleys, eastward and southward from the Bay of San Francisco, the apricot is but little grown, owing to frost troubles. In respect to these the apricot is somewhat less subject to harm than the almond, but it is less hardy than the peach, and has, therefore, a much narrower range of adaptation. The average date of blooming of apricot varieties is about two weeks later than that of almonds.

The apricot is adapted to a wide range of soils, because to the rather heavy, moist loams which its own root tolerates it adds the lighter tastes of the peach root, upon which it is very largely propagated. However, attempts to carry the apricot upon heavier, moister soils by working it upon the plum root have not been very successful, owing to the dwarfing of the tree; and the movement towards the light, dry loams, by working upon the almond root, has failed because the attarhment is insecure, and the trees are very apt to be snapped off at the joining, even though they may attain bearing age before the mishap occurs. The apricot root itself is a favorite morsel with rodents, and is for that reason not largely used. Our mainstay for the apricot, then, is the peach root, and the soils which this root enjoys in localities sufficiently frost free are, therefore, to a great extent, the measure of our apricot area.

Apricot trees are produced by budding on peach or apricot seedlings during their first summer's growth in the nursery row, from pits planted when the ground is moist and warm, at any time during the preceding winter. When there is a great demand for trees, planting in orchard is sometimes done with dormant buds, but ordinarily the trees are allowed to make one summer's growth in the nursery. The trees branch during the first year's growth from the bud, and usually 
come to the planter with a good choice of low-starting lranches from which to shape the low-headed tree, which is universilly preferred. The method of securing such a tree is identical with that already described for the almond, but the treatment of the tree after reaching bearing age, in its third year, is very different from the after-treatment of the almond. The apricot is a rampant grower and most profuse bearer. Unless kept continually in check it will quickly rush out of reach, and will destroy its low shoots and spurs by the dense shade of its thick, beautiful foliage. There is continually necessary, then, a certain degree of thimning of the surplus shoots and shortening of the new growth to continue the system of low branching, to relieve the tree from an excess of bearing wood, and to avoid small fruit and exhaustion of the tree, resulting in alternate years of bearing.

In the coast regions, where the tree makes moderate wood growth, it can be kept in good form and bearing by regular winter pruning. In warmer regions, where the tendency is to exuberant wood growth, the main pruning is done in the summer, immediately after the fruit is gathered. This has a tendency to check wood growth and promote fruit bearing, and where the main cutting is clone in the summer winter pruning is reduced to thinning out shoots, to prevent the tree from becoming too dense and to lessen the work of hand thinning of the fruit later on. In aldition, however, to the most intelligent pruning, much fruit must be removed by hand when there is a heavy set of it, in order to bring the fruit to a size satisfactory to shippers or canners, and to reach the highest grades, if drying is practiced. California apricot orchards are all grown with clean tillage, for the main purpose of moisture conservation. In regions of good rainfall and sufficiently retentive loams no irrigation is required; good tillage will suffice for the production of large fruit and perfection of fruitbuds for the following year. As the trees are becoming older and bearing larger crops the demand for moisture increases, and the use of irrigation water is growing. In most places, however, one irrigation is sufficient, and that is given after fruit gathering, to carry the tree through the last half of its season's work. In the regularly irrigated regions of the state water is periodically applied through the growing season, in such amount and at such intervals as the local climate and soils require.

Though probably all the good varieties of the apricot in the world have been introduced into California during the last half century, and scores of selected seedlings of local origin have been widely tested, the varieties which have survived the tests and are now widely grown are comparatively few in number. Most of the rejected varieties met their fate because of shy bearing, and those which now constitute the bulk 
of the crop are very regular and full bearers under rational treatment. A local seedling, the Pringle, was for many years chiefly grown for the earliest ripening, but this has recently been largely superseded by another local seedling, the Newcastle, which is of superior size and about as early. The European varieties, Large Early and Early Golden, are fine in a few localities where they bear well, and do better in southern California than elsewhere. The universal favorite is the Royal; probably three-fourths of all the trees in the state are of this variety, though recently the area of the Blenheim has been increasing largely. The Hemskirk stands next to the Blenheim in popularity. The Peach apricot is largely grown in the Sacramento valley.

The best apricot grown in California is the Moorpark; in size and lusciousness, when well ripened, it heads the list. It is, however, rather shy in bearing, and is forsaken for this fault in most regions. It shows the best behavior in the Santa Clara valley, and is there retained, in spite of frequent lapses, because of the high prices which it commands at the canneries. About a dozen other varieties are carried in small number by the nurserymen to meet limited local demands. Apricots for canning and drying are graded according to size: Extra, not less than two and one-fourth inches in diameter; No. 1, two inches: No. 2, one and one-half inches; No. 3, one inch. The first three grades must be sound, clean, and free from blemish, and No. 3 must be of good merchantable quality. The shippers and canners require well-colored but only firm-ripe fruit, because both the long rail transportation and the canning process require it; soft, ripe fruit will neither can nor carry. For drying, riper fruit is used, and yet overripeness has to be guarded against to avoid too dark color. For canning, the fruit must be carefully hand-picked; for drying, much is shaken from the trees.

The drying process consists in cutting the fruit in halves longitudinally, dropping out the pit and placing the halves, cavity uppermost, upon light wooden trays. Breaking or tearing the fruit open will not do; it must show clean-cut edges. When the trays are covered they are placed in a tight compartment, usually called a "sulphur box," though it may be of considerable size, and the fruit is exposed to the fumes of slowly burning sulphur, to insure its drying to the light golden color which is most acceptable to the trade. The production of the right color is the end in.view, and different dryers regulate the amount of sulphur and the length of exposure according to the condition of their fruit and their judgment of what it needs. The exposure varies from half an hour to two or three hours, according to circumstances. After sulphuring, the trays are taken to open ground, and the fruit is cured in the sun. Only a very small 
fraction of the California product of evaporated apricots is cured in an evaporator. It requires about six pounds of fresh apricots to make one pound of cured fruit.

A moderate estimate of the yield of apricots might be placed at seven and one-half tons to the acre; extreme yields are far away from this both ways. The apricot is, as a rule, a very healthy tree in California. It is, however, subject to injury by scale-insects of the lecanium group in some parts of the state. During recent years there has been increasing injury by a shot-hole fungus, which perforates the leaves and makes ugly pustules upon the fruit. Such fruit is unfit for canning, except the fruit be peeled, which is little done as yet. It also makes low-grade dried product. This fungus can be repressed by fungicides of the copper class.

\section{VARIETIES OF APRICOTS.}

ALExis.- Large, yellow, red blush; subacid, rich and good. Does well in West. Ripens about July 15. Russian. (Thomas.)

Alexander.-Large, oblong, orange yellow, spotted red; sweet, juicy. Early. Very good; prolific. Russian. (Thomas.)

BudD, J. L.-Large, white, with fine red cheek; sweet, juicy. Very good. Ripens in August. Russian. (Thomas.)

EARly Golden (Dubois's Apricot).- Small, an inch and a fourth in diameter, round oval, nearly smooth; suture narrow, distinct; surface wholly pale orange; flesh orange, moderately juicy, sweet, good, free from the stone; kernel sweet. Early, or ten days before the Moorpark. Hardy, very productive, profitable for market. Origin, Dutchess county, New York. (Thomas.)

Moorpark (Anson's, Dunmore's, Breda, Temple's).--Large, two inches in diameter, nearly round, slightly compressed; surface orange, with a deep orange-red cheek, and with numerous darker dots; flesh free from the stone, bright yellowish orange, rather firm, quite juicy, with a rich, high flavor; kernel bitter; stone perforate, or with a hole lengthwise under one edge, so that a pin may be thrust through. Season medium, or two weeks after midsummer. Requires the shortening-in pruning recommended for the peach. English. Old. (Thomas.)

HARRIS.-Medium, roundish oval, flattened, suture distinct; bright yellow, red cheek; juicy, good. Hardy, productive. Ripens middle of July to first of August. New York. (Thomas.)

RoraL.-Rather large, round-oval, slightly compressed, suture shallow; dull yellow, faintly reddened to the sun; flesh pale orange, firm, juicy, sweet, high flavored, slightly subacid, free from the large, oval, 
nearly impervious stone; kernel bitter. Ripens a week before Moorpark, smaller than the latter, and with a less bitter kernel. French. (Thomas.)

Breda (Holland, Amande, Aveline).-Rather small, sometimes nearly medium (an inch and a half in diameter), roundish, obscurely four-sided, suture distinct; surface orange, with a dark reddish-orange: cheek; flesh deep orange, free from the stone, rich, and high flavored; sweet kernel. Quite early, or a week or two after midsummer. Hardy for an apricot, and very productive. (Thomas.)

Sт. Ambroise.-- Large, roundish, compressed, yellow, shaded dark orange. Prolific. Good. (Thomas.)

Bergetti Blenheim.-- Large, oval, surface orange; flesh deep yellow, juicy, rather rich; stone roundish, not perforate; kernel bitter. Inferior to Moorpark, but rather earlier. English. (Thomas.)

EureKa.-Very early; large, fine; prolific.

\section{APRICOTS.}

Extracts from a paper by Charles E. Bessex, Pb. D., Nebraska.

The apricot (Prunus americana) is a small tree, with a round, spreading top, and a reddish, cherry-like or peach-like bark; leaves smooth, thin, and bright green, ovate or round ovate, with a short point and sometimes a heart-shaped base, obtusely and finely serrate; Howers single, pink white, sessile, or nearly so; fruit globose, smooth, red or yellow, with the sweet, firm flesh nearly or quite free from the large, smooth, flat stone. Original distribution: Northern China, Mongolia, and Manchuria.

In writing about the apricot Professor Bailey says: "It is a prevalent notion that the apricot tree is too tender to be grown in New York state. It will surprise many to learn that the fruit is considerably grown in the state, there being one plantation of many hundred trees. The apricot is as hardy as the peach, and it thrives in the same localities and under the same general cultivation and treatment. There are three chief reasons, I think, why the apricot has remained in comparative obscurity in the horticulture of western New York: (1) Ignorance of the fruit; (2) loss of crop by spring frosts, because of the very early season of blooming of the apricot; (3) the fondness of the curculio for the fruit. To these may be added the fact that we have not yet arrived at an understanding of the best stocks upon which to bud the apricot." The common apricot is usually considered to be less hardy than the Russian kinds, but as to this there is some doubt, and it is very certain that the latter are not as desir- 
able as the former. From all that I can learn of the varieties of the apricot, I am inclined to think that in southern Nebraska the common apricot may be grown in favored places, and that the Russian sorts may be grown somewhat further north.

Black Apricot (Prumes desyearpa). A small, round-topped tree, with much the habit of the common apricot; leaves thin, dull green, ovate, and more or less tapering at both ends, appressed serrate, hairy on the veins below: flowers large, white, solitary or in twos, short stalked; fruit globular, somewhat plum-like, hairy, on a short stem, dull dark purple, the red Hesh sourish and clinging to the plum-like stone. Original distribution: Not certainly known, but probably in Manchuria. This fruit, which is known also as the Purple apricot, possesses but little merit, but is frequently spoken of in horticultural circles.

Japanese Apricot (Prumus mume). A small tree, resembling the common apricot, but with a grayer or greener bark and duller foliage; leaves thickish, grayish green, generally narrower than the common apricot, and long-pointed, more or less hairy along the veins below; flowers single or in twos, white to rose color, sessile; fruit small, yellowish or greenish, the rather hard, dry flesh adhering to the pitted stone. Original distribution: Japan. Professor Bailey, in describing this species, says: "Recently introduced to this country. Its chief representative here is the Bungoume, or so-called Bungo plum. Other forms of this species are Hanahoume, Koume, Gold Dust and Chinese apricots." Of the first variety, he says: "The fruit is small and poor, and I do not see sufficient merit in it to make it worth growing." In Japan it is grown for ornamental purposes.

\section{A KANSAS APRICOT.}

By A. H. Griesa, Lawrence, Kan.

The apricot is not generally grown as a profitable market fruit in this country, owing to its uncertain crop, caused partly by the frost injuring its early blossoms, wind-storms dropping its fruit, and the destructive effects of the curculio.

The Superb is a chance seedling, which was discovered on the grounds of the Kansas Home nursery, at Lawrence, Kan. [A. H. Griesa, proprietor], among hundreds of Russian seedlings; it being one that happened to have a good chance to produce its fine fruit in an out-of-the-way corner, and when found loaded with fruit was a surprise indeed.

It has been grown with the best the world affords, both native and 
foreign. Compared with Early Golden, Moorpark, Alexander, Gibb, Budd, and others, it is larger, more hardy, more productive; a spreading tree; has fruited every year since 1890 , and is now about sixteen years old.

The fruit is the largest size, except Acme or Shense, which never bore but a few samples. It is beautifully colored; the flesh is yellow, and when broken open is like sparkling crystals and the quality is unsurpassed; it is truly superb.

The trees in nursery row are quite distinct from other varietiesstrong, well branched, and are one foot taller than other kinds at one year old. Stark Brothers thus speak of it: "Superb is a seedling from Lawrence, Kan., where we saw it two years in full fruit; has produced more fruit, of larger size, and better, most superb quality, than any other, native or foreign. It is a better and more constant bearer than any hundred others. Exhibited at the Western nurserymen's convention, where its exquisite quality, in comparison with several others, was conceded by all. Superb raises the average in quality and size of this excellent fruit; is worthy of extensive cultivation. Some Eastern firms would make money out of it."

Storrs \& Harrison quote it as "A hardy seedling from Kansas. The best flavored, most productive, hardy apricot yet produced. Quality exquisite, medium size, light salmon color."

It was awarded a first-class certificate by that conservative body, the Massachusetts Horticultural Society, at Boston, in 1897.

It is a home production of which we can justly be proud, for it has had nothing but praise from all parts of the country where it has been tried. Every one can enjoy the delicious fruit of the apricot if he will take pains to ward off the attack of the curculio.

\section{THE "SUPERB" APRICOT.*}

From the Horticultural Visitor.

This is a Russian seedling, growing and fruiting among hundreds of others - the best the world affords, either native or foreign. Compared with E. Golden, Moorpark, Alexander, Gibb, Budd, and others, it is larger, more hardy and spreading tree, more productive; has fruited every year since 1890. The tree is about twelve years old. The fruit is the largest size, except Acme or Shense, which never had more than a few samples. It is beautifully colored; the flesh is yellow; when broken open it is like sparkling crystals, and the quality

* See plate on page 94. 
is unsurpassed; it is truly superb. The trees in nursery row are strong, well branched, and are one foot taller than other kinds.

Others speak of it in high terms, as follows:

"Superb is a hardy seedling from Lawrence, Kam., where we saw it two years in full fruit; has produced more fruit, of larger size, and better-most superb quality - than any other, native or foreign. It is a better and more constant bearer than any hundred others. Exhibited at the Western nurserymen's convention, where its exquisite quality, in comparison with several others, was conceded by all. Superb raises the average in quality and size of this excellent fruit; is worthy of extensive cultivation."

The Superb was introduced a few years since by a well-known Kansas nurseryman who has not pushed it out into the public view as it should have been, for it certainly is a splendid fruit, a heavy bearer, and an apricot that can be grown to perfection. The price is nominal for such a new and splentid fruit. The gentleman who originated the Kansas raspberry, A. H. Griesa, Lawrence, Kan., also did the superb apricot. Knowing it to be a good thing we have been growing a few, and now hav someto sell. They bear young. Try a few.

\section{IRRIGATED FRUIT IN CURING.}

In a paper read before the Southern California Pomological Society, at Riverside, J. H. Reed, speaking on irrigation matters, said (in part): It is claimed that there is a larger percentage of shrinkage in drying irrigated fruit, and I must confess this was my own supposition till my experience convinced me otherwise. You perhaps will pardon reference to this experience, as it seems to the point. Our first apricot orchard was interplanted among young lemons. The lemons were to make the permanent orchard, and all treatment was especially with reference to them. We had plenty of water and applied it generously throughont the year, except when winter rains made it unnecessary. The season after the 'cots had been planted two years we took from twenty-five to seventy-five pounds of extra fine fruit per tree. The next season, third year, they returned from 100 to 300 pounds per tree. The present year, the fourth, they promise double these amounts. So much for quantity.

The first season we kept careful account of results in drying, as we were drying for other parties apricots grown without irrigation. Very much to my surprise, we found that of the unirrigated it had taken 5.6 pounds of green fruit to make one of dried, while of our irrigated apricots it had taken but 4.9. A little thought should have 
relieved us of our surprise. The water taken up by the roots does not pass direct to the fruit, but goes to the leaves, where its food contents are fitted for the fruit and wood growth and the surplus of water goes into the air.

In the rapid growth of the young tree and early fruitage irrigation is an important advantage. Our irrigated trees had produced more fruit at three and one-half years from planting than trees in the neighborhood without irrigation had in twice the time.

\section{APRICOT PITTER AND SPREADER.}

Machinery is being gradually introduced into all the varied operations in canning and curing fruits. It is first, perhaps, a factor of economical handling, but only second to this is the cleanliness which it implies. Among the latest contributions in this direction is an apricot-pitting machine worked out by S. W. Guiberson, of Fillmore. Ventura county. Mr. Guiberson has been experimenting on the machine for three years and has built two which were not entirely satisfactory in results. A third has been completed, too late for the crop of 1898 , though it was given a trial, which demonstrated that it was a much greater success than anything hitherto designed for the purpose. The gentleman mentioned, in a letter to the editor of California Fruit Grower, says: "My pitting and spreading machine is, I think, a success. I did not get it completed in time for this year's apricot crop, except to give it a trial at the end of the season. It took out ninety-five per cent. of the pits and spread the apricots correctly on the trays. It cuts a sufficient number of apricots to cover a tray full at one stroke and spreads them right side up on the tray in one minute, the tray being $8 \times 3$ feet in size. To cut them the proper way for drying they have to be placed in the machine by hand, and this requires three hands and three minutes' time per tray. I claim that three men can cut and load on cars for sulphuring about 150 boxes of apricots a day of twelve hours, and the machine does the work as neatly as by hand pitters."

\section{APRICOT PITS.}

The eream of tartar works at Napa has contracted for 400 or 500 tons of apricot pits, which are being crushed in that city and the kernels extracted and dried. Thus prepared, they are shipped to a San Francisco firm and made to yield up their contents of oil, known to the trade and to chemists as almond oil. 


\section{BROWN APRICOT SCALE.}

At a recent meeting of the horticultural society of Sonoma county, California, a member called attention to the fact that shippers and commission men had decided not to handle any more infested fresh fruit, and referred to the necessity for spraying and discouraging parasites. Speaking of the brown apricot scale, he said very emphatically that it could easily have been checked when first noticed here five years ago, but now it would take a great deal of united and wellsustained work to prevent it from becoming a greater nuisance. Another member mentioned the difficulty of getting men to spray even when the farmers' homes contained papers and horticultural reports that gave the formulix of the best sprays and full directions for their use. The average fruit-grower, said the gentleman, was too lazy or indifferent to perform the manual labor necessary to rid his orchard of the pests that not only cut down his chance for a profit, but his neighbors' as well.

\section{AUSTRALIAN APRICOTS.}

Large crops of apricots have been gathered by orchardists this season in this district, says the Northerm Argus, Australia. The sample has been a uniformly good one, and markets have been easily obtained. Amongst the largest and best of the sort we have seen is a fine sample grown by Mr. C. H. Beaumont, of Penwortham. The fruit is of unusually large size, as will be seen from the fact that some of the apricots weighed five ounces and measured eight inches around. Any nine weighed two pounds, while fifty apricots taken from one case weighed twelve pounds. Mr. Beaumont has 106 trees six years old, from which was picked nearly 7000 pounds of fruit.

\section{SOME KANSAS EXPERIENCE.}

The following individual reports from Kansas fruit-growers convey lots of good ideas on apricot culture:

Ebert Simon, Welda, Anderson county. - I have one apricot tree in bearing, which is prolific every other year; the frost does not eatch it in the spring: the fruit is in demand at home for canning and preserving.

C. A. Blackmore, Sharon, Barber county.-Moorpark did the best with me last season; it bore a full crop of very large fruit. Early Golden and Common apricot bore some. Alexis, Alexander, J. L. Budd, Shensi and Superb are too young to bear with me. In planting the foregoing trees I set them in red soil, 
two to four inches deeper than they grew in the nursery. In sandy soil I set from four to eight inches deeper than they grew in the nursery. I always cut the trees back when setting, and use a good rammer; it is easier and better than tramping with your feet; if the soil is dry pour two or three gallons of water in the hole when half filled with earth, and when the water has settled away fill up and tramp slightly. I do not plant trees of one variety in blocks; I plant a row of one kind, and then a row of a different kind, and so on, being careful to plant sorts that bloom at the same date. I submit the following as a partial guide, according to my observations: Early Golden and Moorpark, first bloom appears April 11; in full bloom April 15; have fallen by May 22.

J. I. Dunkin, Sharon, Barber county.-The apricot is one of the most loved of fruits that is grown in the orchards and is relished either off of the tree, raw, or served on the table; take them dried or canned, and they are sought after, but are tricky, being so often killed in the bloom, or even after the fruit is set. The tree does n't seem hardy enough to be profitable, and is easy to kill above the ground and below the forks. I have lost over fifty per cent. of my trees that way; the bark, or inner bark or sap-wood, dies from the limbs to the ground, while the tree holds its foliage green for some time, but the sap-wood is dead, black and rotten to the ground. They usually sprout up again, but are of little value. I have almost become discouraged with them and about discarded them. The fruit finds a ready sale, as a rule, at a good price, but I can't say I favor planting them for profit. The varieties generally grown here are Alexis, Alexander, Budd, Moor Park, and Early Golden. There will be a good crop this year, but there are too many failures to recommend planting more than a few trees for variety.

A. S. Huff, Enon, Barber county.-Apricots are shy bearers in this valley. I had good crops for nine years. It is a fine, rich fruit, and commands an extra good price; we cannot raise enough, I know of no other fruit that is as ready sale as the apricot. It seems that there are more people that will buy the fruit than any other kind that grows.

E. T. Daniels, Kiowa, Barber county.--I have one Moorpark apricot tree which bears about every other year and it is never troubled with insects; I would advise new beginners to plant this variety; would plant it for both home and market.

W. G. Osborne, Medicine Lodge, Barber county.-I have eleven large, prolific a pricot trees, the fruit of which is not sweet; they are in scattered plantings; they get frosted half the time; we use the fruit in the family; it is in demand, and I think pays. No insect troubles them. I would advise a new beginner to set out an orchard of them and cultivate well.

George T. Elliott, Great Bend, Barton county. - I have fifteen large, sreet, bearing apricot trees; they are prolific in favorable seasons; they are Ealry Golden and Russian varieties. They are planted in a row in my orchard; they often get frosted in the spring. Sell the fruit to my neighbors; it is in demand, but does not pay. Insects do not trouble them much. Would advise a new beginner to plant only for family use, as they get frosted so often. April 10, 1900, our trees were in full bloom, when we had a snow-storm, and we will havo no fruit this season. 
Greorge Ettridge, Roberts, Barton county. - I have but five apricot trees. The Russian stand sixteen feet apart each way; set them out and trim the same as other trees. The tree is hardy; makes a fast growth; is lovely when in full leaf. They are five years old and about ten feet high, with spreading limbs: never get any fruit off them, they bloom so early in the spring the frost always catches them. If the ground freezes hard next winter, I am going to mulch heavily with old hay or straw when it is frozen up and see if that will hold them back in the spring. It used to be practiced in Illinois on apple trees and it was claimed to have held the bloom back two weeks. That is, the mulched trees bloomed two weeks later than those not mulched.

F. S. C. Garrison, El Dorado, Butler county.-I have seven large Moorpark apricot trees in bearing, but they are not prolific. They are planted in an orchard. They often get frosted in the spring. Sell the fruit in El Dorado, but it is not in demand. It does not pay. They are troubled by the curculio, for which I spray. Would not advise a new beginner to grow apricots.

A. D. Arnold, Longford, Clay county.-I have twelve large, sweet Russian apricot trees now in bearing; they are not prolific. They are planted in an orchard; often get frosted. The fruit is in demand, but does not pay; I have none to speak of. Are troubled with the curculio; we do nothing for them. I would advise against them.

Mrs. E. O. Beavers, Ottumwa, Coffey county.--Have twelve large Russian apricot trees, just coming in to bearing, planted in a cluster; they nearly always get frosted in the spring. Will use the fruit at home. It is in demand, and I think it would pay if we could grow them. Insects do not trouble them.

James Dunlap, Detroit, Dickinson county.-I bave about twenty-five Russian seedling apricots now in bearing; some are large: they are very prolific and have borne nearly full crops five times in seven years; some of them are quite sweet. I grow them in an orchard about twenty feet apart; they have been frosted only once before this spring. I sell and can the fruit; it is in demand at one dollar per bushel; they have paid me well; others are not successful; the fruit is troubled with a worm similar to curculio of plum or peach; have done nothing to prevent them. To a new beginner I would advise planting about as many trees as I have, as they are profitable, but would not advise planting a large orchard. My advice is to plant a few, by all means.

J. P. Emery, Cimarron, Gray county.--I have twenty Alexander apricot trees; been planted five years; are large enough to bear; have blossomed two years; but were killed by the late freeze; they are planted in an orchard; the fruit is in demand. I would advise the planting of apricots.

John Bailey, Harper, Harper county.-. Have about three apricot trees now in bearing: the rest were killed during the cold winter of 1898 and 1899; do not remember the names of the varieties I am growing. Some of them are large: part of the trees are ten inches in diameter. They are prolific when they do well: some of them are sweet. I plant them in rows. They often get frosted in the spring; I sell the fruit in Harper. It is in demand, but it does not pay. Spray for the insects. I would advise a new beginner to get some late variety that is hardy and will not winter-kill. 
C. A. Seamiln, Sedgrick, Harvey county. - I have no apricot trees, but the fruit is in demand; they are freer from insects than most fruits. Most all kinds do well here.

F. L. Osborne, Soldier, Jackson county.--I have seventy-five large, sweet, prolific apricot trees in bearing, all named varieties; have them planted in orchard; they do not get frosted in the spring. We find a ready sale for the fruit, as it is in demand, but it does not pay. It is troubled with the codling-moth [?], for which we spray with Paris green. I would advise against the planting of it.

J. W. Williams, Holton, Jackson county.--II have one unnamed apricot tree bearing. It is not large nor prolific. Do not know whether it is sweet or not. They nearly always get frosted. The fruit is in demand, but I have had none to sell. They are troubled with the curculio. We do nothing for them. Some have had good success when planted in orchard.

J. C. Beckley, Spring Hill, Johnson county.-Have three Russian and Golden apricnt trees not yet iu bearing. Older ones were killed by freeze in 1898 and 1899. They were prolific. Seldom ret frosted in the spring. Sell what fruit we can't use at home; it is in demand, and would pay were it not for the insects. The curculio troubles the fruit, for which we do nothing. I would advise a new beginner to plant the Russian and Golden varieties, and go slow.

C. H. Longstreth, Lakin, Kearny county.-Have 250 Russian apricot trees of bearing age but will not fruit this season: the iruit is all large when the trees do not orerbear: all are prolific when the season is favorable, but a full crop canuot be depended on oftener than one year in five. My trees are planted in an orchard. They often get frosted in the spring. Sell the fruit at home as a rule. The fruit is in demand but it does not pay. It is troubled with no insects. Would adrise new beginners to plant it only as a shade or ornamental tree, they are useless as a fruit-tree, but very good for shade.

N. Sanford, Oswego, Labette county.-I have grown apricots but have none in bearing: they are not profitable. My trees were planted scattering, and not in an orchard: they get frosted of ten, and there is no demand for the fruit; it does not pay; would advise against planting the apricot.

I). W. Bradstrect, Dighton, Lane county.--I have a few fairly large apricot trees, planted scattering. The buds often get frosted in the spring: the fruit is not much in demand, and we use it at home; it does not pay. No insects trouble them. Would not advise a new beginner to plant apricots.

D. C. Overly, Hartford, Lyon county.-Has 400 apricot trees of Superb [a Kansas variety, see p. 91] and Sunrise varieties. He says the whole secret of growing apricots is in cultivation and spraying. He says: "I can raise as fine apricots as California and receive as good Irices." "I gather and pack in halfpeck baskets, six dozen in each basket, with tissue paper between the layers. They retail at ten cents perdozen, netting me six dollars per bushel; the demand is great and cannot yet be satisfied." "Plant only Sunrise and Superb, I would not advise the Russian." "If you do not spray well, you will fail." He plants $15 \times 20$ feet. What more is desired to urge the growth of this choice fruit. 
James MeNicool, Lost Springs, Marion county.-I have 200 apricot trees now in bearing, they are large and prolific, but are not sweet. Am growing them in an orchard; they get frosted about half the time: I sell the fruit and seed; it is in demand, but is not a favorite; it pays. The curculio trouble them, but I do nothing for them.

O. W. Heckethorne, McPherson, McPherson county.-. I have ten Russian apricot trees in bearing; they were killed in bloom hy frost this spring; somo are large and sweet, but they are not prolific. They are in scattered plantings. They are in demand, but we use ours at home: they do not pay. Worms trouble them, but we do nothing for them.

J. T. I3arnes, Beloit, Mitchell county. - I have twenty-eight apricot trees; trrelve of them are in bearing; they are J. L. Budd, Catherine, and an American variety, name not known; they are all named varieties excepting two trees. The American and Russian are large and are quite prolific wheu they set a crop; the Catharine and American are sweet. Have some planted in a row and the balance scattered in the orchard. They get frosted sometimes; were killed this spring by the freeze in April. The fruit is in demand, and pays when we have a crop; we can and use ours on the table. Are not much troubled with insects. I would advise a new beginner to plant the J. L. Budd, Alexis, Alexander, and Catherine in rows twenty feet apart each way.

W. B. Stockind, Beloit, Mitchell county. - I have eight large, sweet, prolific apricot trees now in bearing, in seattered planting; the frost does not catch them in the spring: the fruit is in demand; I think it pays. They are troubled with the curculio, but we do nothing for them. Apricots are just as hardy as peaches; the only difference is in the early blooming: had them bearing when peach was killed. There is no finer fruit for canning, drying, and eating out of the hand. I believe if they were budded on Mariana plum they would be hardier than any peach."

John L. Sample, Benan, Morris county.-. I have about twenty large, frolific apricot trees now in bearing; the grafted ones are sweet; they are in scattered planting. Often get frosted in the spring; use the fruit at home, but it is in demand, and it pays. Curculio troubles them, for which wo use slaked lime in the morning while the dew is on the trees, by throwing it into the air. I would advise a new beginuer to plant pits by the thousand. Would not advise against planting apricots. [Who elso has tried air-slaked lime as a dust spray for curculio? SEc.]

James Shatp, Parkerville, Morris county.-- I have about 100 apricot trees now in bearing; they are all named varieties excepting one which is very large: have one large one which was grown from California seed; it ripens the th of July; is a perfect freestone. They are very prolific and sweet. Have grown them in orchard and scattered; they do not often get frosted. Sell them in Iferington; they are in demand, especially the large one, and I am planting it largely; they pay. They are troubled with cureulio, but I do nothing for them. I would adrise a now beginner to plant large varieties, the same as peach trees.

V. W. Hathaway, Council Grove, Morris county. - I have fire or six mediumsized bearing apricot trees. They are Moorpark or the so-called Russian varie- 
ties. They are sweet and ordinarily prolific in a scattered planting: they often get frosted in the spring. The fruit is in demand but we eat some and can the balance while fresh. It does not pay; the curculio troubles them, for which we do nothing. I would advise a new beginner to try a few apricots.

H. L. Ferris, Osage City, Osage county. - I have ten large, sweet, prolific apricot trees in bearing; they are named varieties; planted together; they do not get frosted in the spring. Sell the fruit in Osage City; it is in demand, and it paid until a year ago, when it was killed by the cold winter. They are troubled with curculio, for which I do nothing. I would advise a new beginner to plant mostly Moorpark, fifteen feet apart. I am planting again; sold all I could raise at thirty-five cents per peck.

C. D. Martindale, Scranton, Osage county.-I have five apricot trees now in bearing; they are eighteen to twenty feet tall; the varieties are Russian and Early Golden; no sweet ones; they were prolific when young; are in scattered plantings; have been frosted two or three times. We use the fruit at home, and sell the surplus; it is in demand, but does not pay. I would advise a new beginner to plant Early Golden, Robinson, and Moorpark, but would not advise any one to plant on a large scale, as the trees do not do well after eight or nine years.

Howard Morton, Tescott, Ottawa county. - I had eight Russian apricot trees, but they are all dead now; they were large, but never bore a full crop. I grew them in orchard rows; they often got frosted in the spring. They were troubled with the curculio; sprayed for them, but it was not well done. Would not advise the planting of apricots.

F. T. M. Dutcher, Phillipsburg, Phillips county.-I have about nine apricot trees now in bearing. They are about six inches in diameter and not very prolific; none of them are sweet. Grow them in rows; often get frosted in the spring. Use the fruit in the family; it would be in demand if we had any to sell; does not pay. Have never been troubled with insects: I spray. Would advise against them.

John Hinds, Olcott, Reno county. - I have a few apricot trees, but they do n't do well here, as the frost gets them at blooming time.

H. C. Hodgson, Little River, Rice county.--I have fifteen apricot trees now in bearing. They are the Russian and not named, not prolific nor sweet; have them among apple trees. They often get frosted in the spring. Use the fruit in the family. They are troubled with the codling-moth, for which I have sprased. I would advise against planting them.

D. M. Aclams, Rome, Sumner county. - I have two sweet, prolific apricot trees in bearing; they are ten feet high; but they are not sweet. The fruit is in demand, but we use it at home. They often get frosted in the spring; they do not pay in a commercial way; no insects trouble them.

M. E. Wells, Smith Center, Smith county.-I have six bearing apricot trees. The apricots are the size of a small peach and about as sweet, and are prolific in farorable seasons. They are planted scatteringly and get frosted about half the 
time. The fruit is in demand and I think it pays; they are troubled with no insects. The apricot is as sure a crop here as the peach; would set them twenty feet apart.

C. H. Taylor, Eskridge, Wabaunsee county.-I have twenty-five sweet, prolific, medium-sized apricot trees now in bearing: they are planted scatteringly; seldom get frosted in the spring. Use all the fruit we can and sell the balance in the local market; it is in demand, and pays. The same insects trouble it that trouble the peach; I destroy the windfalls and spray to prevent them. I would advise a new beginner to plant $10 \times 20$ feet apart and cultivate thoroughly, separate from peach.

Alexauder spiers, Linn, Washington county.-I bave fire unnamed apricot trees in scattered planting; they often get frosted in the spring. The fruit is not in demand; it does not pay. They are troubled with no insect.

\section{APRICOTS FOR THE TABLE.}

Te append here a few good recipes for preparing apricots for table use :

Cammed Apricots.- One pound of sugar, four pounds of apricots, one quart of water. Take fine ripe apricots, pare, core, and throw them into cold water. When you have sufficient to fill one or two jars, lift them carefully from the water, weigh, and put them in a porcelain-lined kettle; cover with boiling water, bring quickly to the boiling-point, and then stand them over a moderate fire, where they will scarcely bubble, until tender. While they are cooking, put the sugar and water into another kettle, stir with a wooden spoon until the sugar is thoroughly dissolved, then with a skimmer lift the apricots from the water, drain a moment, then slide carefully into the boiling syrup; continue until the bottom of the kettle is corered: boil until the apricots are sufficiently tender to admit a straw, then lift them carefully one at a time into the jar, and seal. (Mrs. Rorer, in "Canning and Preserving.")

Preserved Apricots.-Pare, cut into halves, and remove the stone. Weigh, and to each pound of apricots allow allow one pound of sugar and half a dozen apricot kernels. Put a layer of the apricots in a bowl or jar, then a layer of sugar, then a layer of apricots, then a layer of sugar, and so on until all is used. Cover and stand aside over night, add the kernels, and bring quickly to a boil; then simmer until the apricots are tender and clear. Lift carefully, one at a time, and put in glass jars or tumblers. Stand, aside to cool, pour over the syrup, and tie up. Nectarines may be preserved in the same way. (Mrs. Rorer, in "Canning and Preserving.")

Apricot Marmalade.- Rub the apricots, to remove the fuzz, but do not pare them. Cut in halves, remove the stone, and to erery pound of apricots allow a half-pound of sugar. Put the apricots in a porcelain-lined kettle, add sufficient water to cover the bottom; cover, and heat slowly to boiling-point; then stir, and mash until fine; add the sugar and three or four kernels, blanched and pounded to a paste, to every quart of marmalade. Boil and stir continually for fifteen minutes, then stand over a moderate fire, and cook slowly twenty minutes longer. 
Stir occasionally, that it may not scorch. Put away in stone jars. Plum marmalade may be made in the same way. (Mrs. Rorer, in "Canning and Preserving.")

Compote of Green Apricots.-Wipe the down from a pound of quite young apricots, and stew them very gently for nearly twenty minutes in a syrup made with eight ounces of sugar and three-fourths of a pound of water, boiling together the usual time. (Mrs. Hale.)

Drying Apricots.-Allow the fruit to be as well ripened as possible without being mushy. Cut the fruit clean in halves, not half cut and half break. Get the trays in the sulphur box as soon as possible after spreading, or spray or sprinkle them a little before putting in. Expose to sulphur fumes an hour or more, the object being to keep the cured fruit the same color as the natural, fresh-cut fruit. A pricots blacken in drying unless sulphured. When nearly dry the trays may be stacked and the curing continued in the shade. There are fruit graders which grade the cured fruit very accurately, except that slabs and discolored pieces must be thrown out by hand.

Apricots make good pies.

Dried apricots are good simply stewed and sweetened. 


\section{NECTARINES.}

We have been able to find but few nectarine growers in Kansas, and the few quoted do not speak very encouragingly of its value. Personally we believe it susceptible of protitable culture to add to the variety of home fruits. Possibly some of our horticulturists will take it in hand and produce varieties suited to our state. It ought to be as good as the peach, and freedom from fuzz, velvet or down must surely be a pleasing and valuable characteristic. If it is simply a "peach with a smooth skin," then why is it not as worthy as a "peach with a fuzzy skin"?

Downing mentions thirty-one distinct varieties.

\section{DEFINITIONS.}

Century Dictionary: Sweet or delicious as nectar. A variety of the common peach, from which its fruit differs only in having a rind devoid of down and a firmer pulp. Both fruits are sometimes found growing on the same tree.

Stander Dirtionren: A smooth-skimed variety of peach. Spanish nectarine, the plum-like fruit of the West Indian tree, Chrysobalanus icaco; also called cocon plum. It is made into a sweet conserve which is largely exported from Cuba.

\section{THE NECTARINE.}

From Downing's "Fruit and Fruit-trees of America."

The nectarine (Persica vulgaris) is only a variety of the peach with a smooth skin (I'erhe liswe, or Brugnon, of the French) in its growth, habit, and tree. The fruit, however, is rather smaller, perfectly smooth. without down, and is one of the most wax-like and exquisite of all productions for the dessert. In fluvor it is perhaps scarrely so rich as the finest peach, but it has more piquancy, partaking of the noyau or peach-leaf flavor. The nectarine is known in northern India, where it is called moondla aroo (smooth peach.) It 
appears to be only a distinct, accidental variety of the peach, and this rendered quite certain since there are several well-known examples on record of both peaches and nectarines having been produced on the same branch - thus showing a disposition to return to the natural form. Nectarines, however, usually produce nectarines again on sowing the seeds; but they also occasionally produce peaches. The Boston nectarine originated from a peach-stone. The nectarine appears a little more shy of bearing in this country than the peach, but this arises almost always from the clestruction of the crop of fruit by the curculio, the destroyer of all smooth-skinmed stone fruit in sandy soil. It is quite hardy here wherever the peach will thrive, though it will not generally bear large and fine fruit unless the branches are shortened in amnually. With this easy system of pruning, good crops are readily obtained whererer the curculio is not very prevalent. The culture of the nectarine is in all respects precisely similar to that of the peach, and its habits are also completely the same.

Thomas"s "American Fruit Culturist" says: "The nectarine being nothing more than the peach with a glossy skin, the same rules for cultivation will apply equally to both, with the exception that, as its smooth surface renders it eminently liable to the attack of the curculio, special attention must be given to the destruction of this insect. The nectarine is usually inferior, and has more of the noyau flaror than the peack, and the shoots are of smoother and mort compact srowth." Then follow descriptions of freestones, pale flesh, six varieties: freestones, deep yellow flesh, three varieties: clingstones, pale flesh, two varieties; clingstones, yellow flesh, one variety.

James Alexander Fulton, who wrote a standard work on "The Peach," says: "There is abundant evidence that the nectarine is a mere accidental production of the peach. The general characteristics are identical, while the difference is but slight, and consists principally in the presence or absence of the pubescence on the skin. The nectarine, both in tree and fruit, is not so vigorous, hardy or durable as the peach; it is more easily affected by disease and the attacks of insects: sheds its fruit more easily, and oftener fails to produce a crop."

\section{WHITE NECTARINES.}

Regaring the nectarine, a fruit that is not near so highly appreciated in this country as it is in Europe, the Hanford (Cal.) Sentinel, two or three weeks ago, said: After a successful run of about two solid weeks picking, cutting and drying white nectarines, A. IT. Lane, whose ranch is near Grangeville, reports that he has cleaned up and sold his crop, and that the same has netted him $\$ 150$ an acre. 
Mr. Lane is one of the most intelligent of our orchardists, and runs his place on practical plans. He is perhaps the largest grower of white nectarines in the valley. He states that the nectarine is a more sure bearer than the peach, apricot, or prune, and is more profitable from the fact that the nectarine resists the early frost better, requires less pruning, and holds a larger weight of fruit without breaking down.

The cost of putting the cured white nectarine in the market is about thirty-five dollars per ton, or about the same per ton as apricots: and nectarines dry away about five to one. or a little less than some peaches.

\section{SOME KANSAS EXPERIENCES.}

C. A. Blackmore, Sharon, Barber county, - Nectarines seem to be too tender in fruit-bud to eseape the [spring] frost, although they bear some erery year.

J. R. Dunkin, Sharon, Barber county, - The nectarine has n't been planted to any great extent here yet-only a ferw trees here and there; they seem to do well in this vicinity. Some think they are not profitable; others think they are. Can't say what their future popularity may be, but think they should be more extensively planted. I favor giving all kinds of fruit a fair and impartial trial, to test their qualities, and give them our favor.

S. F. C. Garrison, El Dorado, Butler county, - I had a ferw nectarine trees, but they are now all dead; they were not prolific: they got frosted often in the spring. We did not use the fruit; there was no demand for it. The curculio troubled them. Would not advise a beginner to try nectarines in this locality.

John Bailey, Harper, Harper county,-- Have grown nectarine trees in seattered plantings, but have none now in bearing; all are dead. Would not advise any one to plant them.

J.C.Beckley, Spring Hill, Johnson county. - Hare one nectarine tree, which is not very prolific; they get frosted about as often as peaches do. Use the fruit at home; have never sold any; don't think it would pay. 'They are troubled with the curculio, but we do nothing for it.

C. H. Longstreth, Lakin, Kearny county, - I have three nectarine trees, not bearing; they are named varieties; they of ten get frosted in the spring. Do nothing with the fruit; it is troubled with no insects. Would advise new beginners to let the nectarine alone.

James McNicol, LostSprings, Marion county.- Has grown nectarines on the game principle as peaches, but thinks the peach far preferable, as it is not so liable to be stung by the curculio.

James Sharp, Parkerville, Morris county, - Has three nectarine trees now in bearing; they are not very large; he does not know the names of them; they are about as prolific as the peach. Do not get frosted in the spring; uses the fruit at home; does not pay. They are troubled with the curculio; he does nothing for them. Would not advise any one to plant it. 



\section{CHERRY INDEX.}

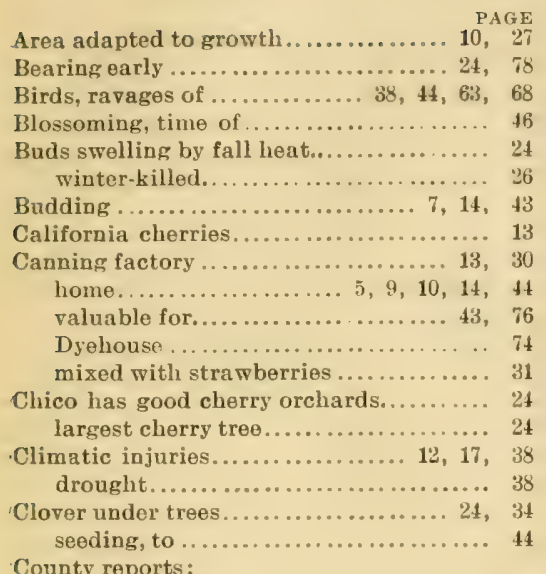

County reports:

Barber

Barton ....................... 47

Bourbon ........................ 48

Butler........................... 48

Chase ............................ 48

Clay........................... t8

Cowley........................... 48

Decatur......................... 48

Franklin....................... 49

Harper.................... 49, 50

Jackson......................... 50

Jefferson........................ 50

Johnson......................... 51

Kearny ........................ 51

Labette......................... 51

Lane............................. 52

Leaveaworth ................... 5.

Linn........................... 52

Lyon ........................... 52

Mitchell.......................... 52

Montgomery ........................ 53

Morris........................ 53

Nemaba....................... 53

Osago .......................... 54

Phillips.......................... nt

Reno...................... 54, 55

Smith........................... 55

Sumner ....................... 55

Washington.................. 55, 56

Wabaunsee ..................... 55

Wyandotte...................... 56

Cultivation ........... 8, 10, 18, 24, 29, 32 $34,40,43,45,77$ deep plowing ............... 17, 32 Cover crops..........10, 19, 24, 29, 37, 40
Crowded out by other fruits ................ PAG

Definitions, Standard Dictionary........ 3

Century Dictionary.................

Diseases.......................... 12, 87 black-knot................12, 28, 88 preventive and remedy .......... 89 brown $\operatorname{rot} \ldots \ldots \ldots \ldots \ldots \ldots \ldots \ldots, 12,89$ bursting orcracking of bark, 12, 13, 38, 39 climatic injuries................ 12, 38 foot-rot........................ 28 gum ....................... 6, 25 leaf-blight .............12,39, 41, 87 lea $\mathrm{i}$-spot ...................... powdery mildew ................ 12, 83 remedies ...................... 83 shot-hole......................... 83 remedies ....................... $\$ 33$ sun-scald ........................ 12 unripe wood ........................ 13

Exporting large quantities.............. 13

Elevation of orchard ...........14, 17, 27

Fertilizing.............. 8, 10, 17, 24, 40 barn.yard litter................... 17

wood ashes........................ 17

Frost, spring injury by................. 17

Fruitfulness .................. 14, 26, 39

Fruit cracking................... 17, 25 spurs......................... 10 $\operatorname{larg} \theta \ldots \ldots \ldots \ldots \ldots \ldots \ldots \ldots \ldots, 14,62$ diameter of ...................... 15

Grafting dwarf trees................... 8 plastic.......................... 71 root ............................ 69 scions ......................... 71 side.............................. 70 top ............................ 8, 14

Growing in Northwest................. 2t

Hardiness compared with other fruits .... 27 Insects ..........................82, 87 aphis..................4, 12, 87, 89 remedy.................... 12, 88 bectle, bark...................... preventive .................. 89 beetle, June.......................... 89 borer ............................. canker-worm .................... 82 curulio ....... 12, 38, 41, 44, 82, 83, 85 catcher ....................... 86

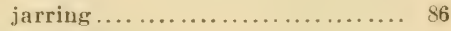
preventive ..................... $8^{4}$ remedy .......................... 84 spray for.................... 5.5 cicada $\ldots \ldots \ldots \ldots \ldots \ldots \ldots \ldots \ldots, 89 . \ldots \ldots$ remedy...................... 89

fall web-worm ..................... 82 
Insects:

leaf-crumpler .................. 82

slug ............................. 84 remedy...................... 84

saw-fly $\ldots \ldots \ldots \ldots \ldots \ldots \ldots \ldots \ldots . . \ldots, 84$

remedy..................... 84

tent-caterpillar .................. 82

Kansas, sure crop in .................. 45

little danger of raising too many in ... 45

Market for, best......................... 31

Medicinal qualities of................... 91

Money in................................. 64

Mulching. ............... 17, 29, 77 dust......................... 34, 45

Noble fruit . . . . . . . . . . . . . . . . . . 69

Nurserymen, patronize reliable.......... 37

Nursery stock, one-year-old trees... .14, 37, 40 two-year-old trees ......... 14, 17, 37, 40

New York, western, sour cherries in ...... 66 sweet chierries ...................... 67

Orchard........................... 72 experience...................... is

for profit..................... 76

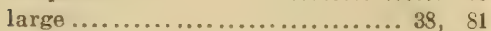

location................... 29, 40, 73

San Jose ....................... 25

Origin........................ 5, 43

Packages............10,19, 37, 41, 79, 81 ten-pound boxes................ 25, 26

Packing............................. 81

diameter of fruit ................. 15

table............................ 19

homest.......................... 20

Pasturing the orchard ................ 10

Personal contributions and clippings:

Adams, D. M ..................

Arnold, A. D ...................... 48

Bailey, L. H... 9, 13, 21, 39, 61, 67, 73, 76, 80

Bailey, John .................... $\$ 9$

Baldwin, S. J . . . . . . . . . . . . . . 16, 53

Barnes, J. T.................... 5,2

Baxter, Mr........................ $35^{\circ}$

Beckley, J. C...................... 51

Bessey, Chas, E................... 57

Berryhill, J. G.................. 20

Bilsing, J. H.................... 45

Blackmore, C. A ................... $\$ 6$

Bradstreet, D. E................. 52

Budd, Prof. J. L............. 20, 22, 23

Butterfield, Mr.................... $36^{\circ}$

Callaway, Mr.................... 36

Cecil, J. F..................... 33

Cellar, W. D ...................... 56

Chambers, S. W .................. 65

Clark, Isaac...................... 49

Colman, Mr....................... 23

Cutter, H. S.................... 50

Daniels, E. T...................... 46

Dixon, F. W .................... 50

Dickens, Albert.................... 45

Diehl, E. P..................... 51

Downing, A. J. ............... 5, 41

Dunkin, J. R..................... 47

Dutcher, F. T. M1................. $5 t$
Personal contributions and clippings;

Ervine, J. M....................... 36

Elliott, Geo. T. ................. 47

Ettridge, Geo.................... 46

Fleharty, W. M. ................... 52

Garrison, S. F. C................ 45

Geiger, Mrs. W................ *ก๊ 26

Geiger, W. R. ..................... 26

Goodman, L. A. ................... 36

Gray, E. M..................... 50

Griesa, A. C. \& Bro.................. 60

Hansen, Prof, N. E. ................. 69

Harris, H. T. .................. 58, 75

Hathaway, V. E. ................. 53

Hector, Robert ................... 64

Heikes, IV. F..................... 15

Hildreth, Geo....................... 51

Hinds, John ..................... 55

Hinkley, Mr.................... 23

Holsinger, Maj. F.............. 36, 56

Hopkins, G. W................... 35

Huff, A. S. ................... 47

Johnson, G. W. .................. 16

Johnson, J. W. ................... 11

Kean, Mr........................ 39

Kirkpatrick, E. W. M.............. 16

Kirtland, Professor.................. 58

Kiser, J, J................... 30, 36

Linton, S. H................ 27, 28

Longstreth, C. H................... 51

Loudon, Mr.................... 6

Martindale, C. D................... 54

May, Dick...................... 48

Mas, J. E. ....................... 36

Murray, N. F .................... 16

Myers, Dr. J..................... 54

Nichols \& Lorton.................... 16

Osborn, F. L..................... 50

Osborn, W. G..................... 46

Overly, D. C...................... 52

Perkins, C. H................. 39, 79

Powell, G. Harold.................... 9

Powell, Professor.................... $7 t$

Reed, David ..................... 23

Reed, John.................... 48

Ross, J. C...................... 53

Sample, John E................. 53

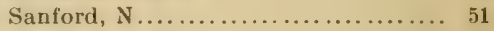

Sauer, A. ...................23, 77

Saxe, J. B..................... 48

Sayles, J. H .................... 48

Scoon, Mr..................... 39

Sinnock, J. P...................... 37

Skinner, W. H................... 32

Smith, B. F ..................... 43

Spiers, Alexander................. 56

Stayman, Dr. J ................... 52

Swigart, A. N .................... 42

Taylor, C. H ..................... 55

Taylor, I. M........................ 49

Terry, H. A................... 21, 23

Tunnell, Rev. R. M ............... 77

Van Deman, H. E.................. 74

W aggover, P................... 49 
Personal contributions and clippings :

Waugh, Prof. F. A ................ 61

Wells, M. E...................... 55

Wotmore, E. F.................... 26

White, D. D.................... 50

Wickson, Edward J ............... 13

Woolverton, E. K................... 55

Pickers ..................... 20, 45, 81 pay.....................41, 79, 80

Picking..... 8, 10, 13, 19, 26, 32, 37, 76, 81 by stem........................ 20 ladders, convenient.............. 19, 20 losses in .......................... 32 number of times over.............. 41

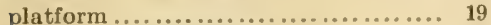
shanty or packing-room.......... 19, 26 ship in car lots.................... 38 sorting...................... 10, 15

Planting .................... 17, 29, 32 age......... 10,14, 17, 37, 40,46, 78 crop between rows........ 19, 29, 37, 40 should not be done ............... 24 raspberries..................... 40 distance.......... 8, 10, 18, 24, 29, 39 $40,44,46,74,78$

fall............................. 37

for car-lot shipments............. 36

only in spring....................

puddle roots .................... 32

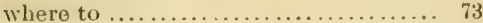

Prices, wholesale ...................... 15 high..................... 25, 26, 64

Profits........ 4, 10, 11, 26, 28, 39, 45, 79

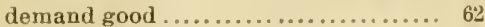
planting for....................... 20 greater than in apple growing........ 38

Propagation ......................... 7 seed preparation of .............. 7 planting...................... 7 preserving over winter............ 7 persistent ...................... seedlings, good................. 43 to sprout.................... 65 without kernel.................. 43 vitality ...................... 7

Protection ......................... 17, 29 Pruning........... 8, 10, 19, 24, 27, 29, 32 $33,37,40,42,44$

time for low heads..

Rabbits and borers seldom bother........

Rheumatism, cherries good for............

Santa Clara valley......................

Seedlings, good..................... $\$ 3$

Shawnee county. in.................... 38

Shipping......................... 19, 25

Slope of orchard ground........... 17, 29

Sod in the orchard...................... 10

Soils, 7, 10, 14, 17, 24, 25, 26, 30, 32, 40, 41, 45 drainage... 24, 26, 27, 29, 30, 43, 66, 77 unsuitable...............14, 28, 38, 43 wet places ......................... 7

Spraying............................. 41 aphis.....
Spraying :

arsenate of lead...................

arsenical solution ................... 82

carbolic acid..................... 91

cherry slug, for ................... $8 t$

Bordeaux mixture.................. 41

curculio preventive................ \& 82

remedy ..................... 83

fish-oil soap......................... 1:

kerosene emulsion.................. 12

London purple.................... 8.

Paris green .......................

white arsenic ................... \$ $\$_{2}$

Stocks:

Mahaleb, $10,14,17,22,36,37,42,54,55$, is

Marianna plum for................. 69

Mazzard, 7, 10, 14, 17, 22, 36, 37, 69, 78 Morello ................. 8, 15, 17, 36 raising ......................... 7

Sure croppers......................... 79

Table delicacies, recipes :

cauning... 5, 9, 10, 14, 43, 44, 74, 66,91 charlotte...................... 91 compote......................... 9

compote of Morellos.................. 92 dried fruit................. 13, 68, 92 after cooking................. 00

jam............................ 92

jelly.......................... 92

pickled......................... 93

pie ........................ 5, 93

with sweet apples.............. 31

preserves......................... 93

spiced.............................. 93

syrup............................ 93

Time of ripening...................... 11

Trees:

age to plant........10,14, 17, $37,40,46$ climatic injuries to $\ldots \ldots \ldots \ldots \ldots .12,38$ diseases of ......................... 12 dwarfed.........................., 14 growth, stalwart................. 14 hang long on...................... 37 large....................... 8, 28, 77 none are long-lived........... 8, 24, 28 ornamental.....................28, 44 profitable......................... 80 roadside.....................4, 6,42 marking ...................... 6 second-class never cheap.......... 17, 45 Switzerland, old, in ................ 30 trunks protected...................... 13

Uses of fruit......................... 5 recipes........................ 91

Vacaville, Cal., district............13, 25 very early ....................... 24 first box, fancy price......... 24, 25 Value................... 30, 38, 39, is Varieties and classes............. 30, 58, 75 best for Kansas.................... 11 unnamed - some good........... 31, 46 for local use ................... 11, 61 plant but fow .................... 41 Amarelle............. 9, 11, 22, 23, 7t 
Varieties and classes:

Baldwin............... 15, 16, 52, 54

Bastard........................... 3

Bay............................ 3

Belle de Choisy........... 16, 53, 59, 75

Belle Magnifique ............. 16, 60, 75

Belle d'Orleans.................... 25

Bigarreau..........3, 9, 11, 12, 14, 21 $27,38,43,56,77$

Bing............................. 25

Bird .......................... 3, 9, 63

Black Eagle................... 44, 79

Black Heart ...................... 3

Black Republican .................. 25

Black Tartarian.. 3, 9, 11, 14, 25, 27, 44 $52,53,61,65.75,76,77,79,80$ popular eating variety............ 25 keep long ...................... 25

Bouquet Morello .................. 23

Bruesler Braun..................23, 61

Brussarbian ................... 23, 61

California cherry, paper on.......24, 76

Centennial ......................... 25

Cerise d'Ostheim.................22, 23

Choke........................... 3

Cleveland Bigarreau,............... 25

Criotte du Nord....................... 23

Dikeman........................ 12

Double Natte...................... 23

Downer's Late Red.................. 79

Dukes.............6, 9, 14, 20,21, 28 $38,42,43,56,75$

Dwarf................... 3, 8, 9

Dyehouse....21, 31, 42, 47, 48, 50, 52, 54 $56,58,61,69,74,75,77,78$

Early Purple Guigne...............14, 25

Early Richmond....4, 5, 9, 11, 15, 16, 21 $22,23,27,31,35,36,37,38,39,40$ $42,44,46,47,48,49,50,51,52,53$ $54,55,56,61,63,69,74,75,77,78$ most popular variety in West..... 39 hardiest........................ 39

Elton ............................ 79

Empress........................ 52

Empress Eugene.............48, 49, 53

íean ........................ 6

Governor Wood.......4, 9, 16, 25, 42, 44 $47,50,53,58,61$

Ground ........................... 3

Guigne Marbre.................... 14

Heart. $\ldots \ldots \ldots \ldots \ldots 11,17,35,43,41,75$

Improvod Dwarf Rocky Mountain.... 9

Jerusalom.......................... 77

Kentish ..................... 3, 5, 16

King's Amarelle .................. 23

Knight's Early Black............ 14, 25

Late Duke.............. 37, 39, 59, 75

Late Richmond.............. 21, 22, 50

Laurel ............................ 3
Varieties and classes:

Lewelling....................... 14

Louis Philippe.. 9, 11, 39, 44, 53; 66, 75

Lutovka ....................... 23

Mahaleb......................., 3, 10

May Duke..... 3, 4, 9, $16,27,46,47,50$ $51,52,53,58,59,75$

Mazzard............... 3, 6, 7, 8, 9

Mercer....................... 52, 75

Mezel............................ 12

Montmorency, 4, 9, 11, 15, 16, 22, 27, 31 $35,36,38,39,40,41,42,44,46$ $47,48,49,50,51,52,53,56,61$ $63,66,67,69,73,75,77,78,79$

Morello.... 3, 4, 6, 9, 11, 14, 15, 16, 21 $21,22,23,27,28,31,35,37,35$ $39,40,41,42,43,44,46,47,48$ $49,50,51,52,53,54,55,56,61$ $63,66,67,72,73,74,75,77,78$

Napoleon ........ 9, 11, 12, 14, 25 $44,61,75,79,80$

Olivet........42,49,52,58, 60,61, 75

Orel Sweet ..................... 21, 23

Ostheim.. 3, 11, 22, 27, 31, 39, 44, 48, 49 $50,52,53,56,61,66,69,77$

Ostheimer Weichsel .................. 23

Oxheart....................... 3, 4

Perfumed ......................... \&

Reine Hortense........... 9, 16, 60, 75

Robert's Red Heart............. 12, 79

Rockport Bigarreau. ..............., 14

Royal Ann ................... 14, 25

Royal Duke................... 16, 48

Russian varieties......... 22, 23, 61, 73

Sand, native............... 9, 57, 58

Nebraska..................... 57

Schatten Amarelle............... 23, 61

Scotch........................... 53

Sklanka.........................

Sour cherries................ 9, 10, 61

Spate Amarelle.................... 23

Sudie........................ 27, 31

Sula Hardy ......................... 50

Sweet cherries...... 9, 28, 44, 61, 67, so

Terry .......................... 23

Valdimir...................... 48, 49

Vilna Sweet...................... 21

Wild black........................

Wild Virginia....................... 5

Windsor.... 9, 12, 27, 44, 52, 65, 75, 79

Wragg.... 22, 27, 31, 36, 50,51, 52, 53

Wragf ...... $54,56,60,61,69,75,77,78$

Yollow Glass....................... 21

Yollow Spanish........ 25, 27, 51, 53, 79

Watoring............................ 45

Wiud-breaks.................... 17, 29

Winter injury...................... 24, 27

Wood ................................. 6

Yield .................... 14, 26, 29, 39 


\section{APRICOT INDEX.}

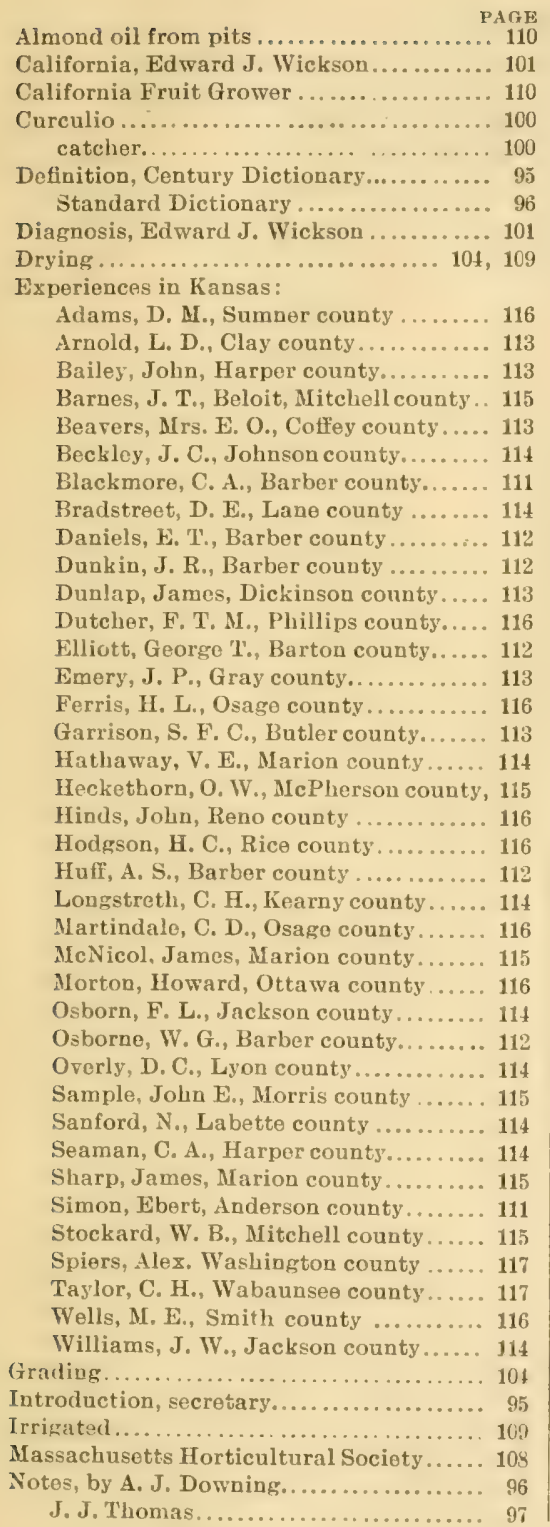

Origin, Professor Bailey............... PAGk

Pits, almond oil from .................. 110

Pitter and spreader ..................... 110

Pruning.............................. 100

Scale, brown........................ 111

Spraying............................. 100

Stocks for............................ 101

Superb, A. H. Griesa ............... 107, 109

Horticultural Visitor................ 108

Table use - receipts .................. 117

canning...................... 117

compote......................... 117

drying ............................ 118

marmalado ........................ 117

pies ............................. 118

preserved ........................ 117

stewed .............................. 118

Varieties:

Alexander................. 99, 105, 105

Alexis........................ 99, 105

Australia.......................... 111

Black............................ 107

Blenhoim ........................... 106

Breda ......................,96, 106

Budd, J. L................. 99, 105, 108

Catherine......................... 99

Chinese .......................... 107

Eureka......................... 1C6

Golden Early ............ 95, 104, 105, 108

Gibb ........................ 99, 108

Harris ...................... 99, 105

Hemskirk...................... 106

Home ............................ 95

Japanese....................... 99, 107

Large Early ....................... 104

Nonteranet ...................... 94

Moorpark.......... 95, 99, 101, 105, 108

Nicholas ........................ 99

Orance............................ 96

Pringle............................ 104

Remers.......................... 95

Royal .................... 99, 104, 105

Russian................... 98, 99, 107

seedling........................ 97

Kansas...................... 95

St. Ambroise................... 99, 106

Superb............... 95, 107, 108, 109

Turkish ..................... 96, 99

wild .......................... 96

Why not more planted ?............... 106

Yield ............................. 105 


\section{NECTARINE INDEX.}

\begin{tabular}{|c|c|}
\hline PAGE & Experiences in Kansas: \\
\hline ost of curing... & Longstreth, C. H., Kearny county..... 121 \\
\hline efinition, Century Dictionary.... & McNicol, James, Marion county.... \\
\hline Standard Dictionary.................. 119 & Sharp, James, Morris county. . \\
\hline speriences in Kansas: & Introductory, secretary.. \\
\hline Bailey, John, Harper county & Notes, by Downing. \\
\hline Beckley, J. C., Johnson county..... & Thomas ........ \\
\hline Blackmore, C. A., Barber county....... 121 & J. A. Fulton........ \\
\hline Dunkin, J. R., Barber county...... & White, from California.......... \\
\hline Garrison, S. F. C., Butler county. & \\
\hline
\end{tabular}







